LIVIA COSTANZA

\title{
THE SECURITY OF INTERNATIONAL INVESTMENTS - A SYNTHESIS OF IMPACTS ON PUBLIC POLICIES AND DOMESTIC LAW OF HOST STATES
}

\section{LLM DISSERTATION}

(LAWS 592)

FACULTY OF LAW

VICTORIA UNIVERSITY OF WELLINGTON 


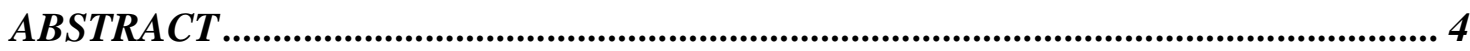

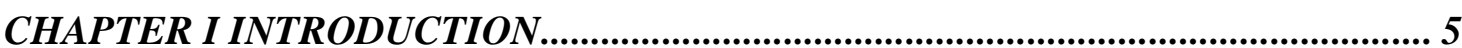

CHAPTER II A BRIEF HISTORICAL REVIEW OF THE EVOLUTION OF THE CONCEPT OF SECURITY OF FOREIGN INVESTORS UNDER INTERNATIONAL

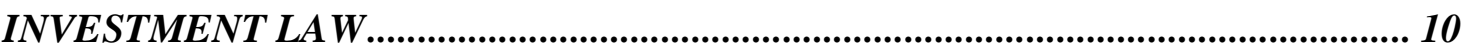

A A Slow Evolution of Law: An Increasing Security with Uncertain Limits ....... 12

$1 \quad$ A basic protection of investment and investors............................................... 12

2 Development of a large BITs' network …….................................................... 16

(a) The collapse of the Multilateral Agreement on Investment...................... 21

(b) Increased participation of NGOs in investment arbitrations.................... 23

B A Security Based on International Arbitration Tribunals .................................. 26

$C \quad$ The New Content of International Investment Law ........................................ 30

$1 \quad$ Fair and equitable treatment standard to security against administrative

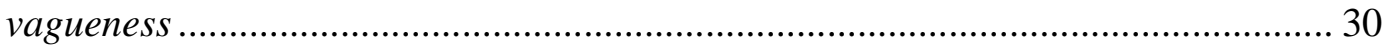

2 Prohibition of the arbitrary to protection against the evolution of the law...... 30

3 An international contract law to an international legal security of contracts . 36

CHAPTER III STUDY OF THE IMPACT OF CONTRADICTORY IMPERATIVES IN PUBLIC LAW OF HOST STATES IN RELATION TO THE SECURITY EXPECTATIONS OF FOREIGN INVESTORS ....................................................... 39

A Public Policies Jeopardised by the International Security of Investments............ 40

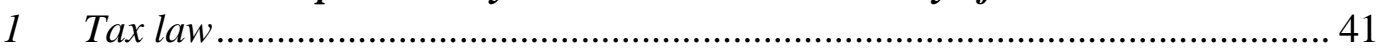

(a) Scope of coverage of taxation provisions in investment agreements ....... 41

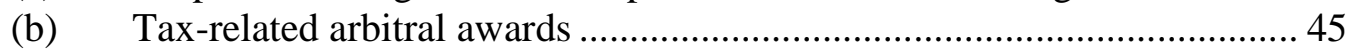

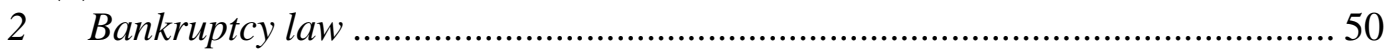

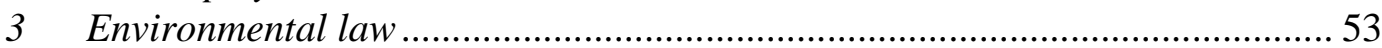

(a) Scope of coverage of environmental provisions in IIAs.......................... 55

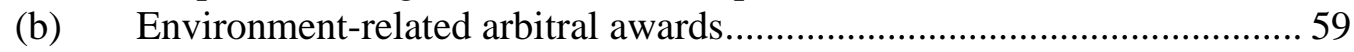

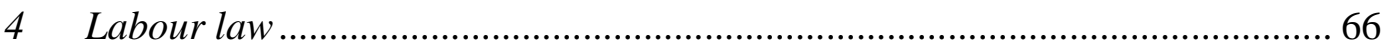

$5 \quad$ State taking of property sector ................................................................... 74

(a) Scope of coverage of taking provisions in investment agreements .......... 74

(b) Expropriation-related arbitral awards ................................................... 77

B The Right to Regulate in International Investment Agreements ............................ 82

$1 \quad$ Alternative formulations for a new treaty language ...................................... 82

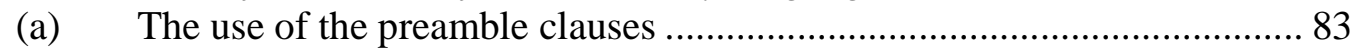

(b) The inclusion of regulatory measures articles ....................................... 84

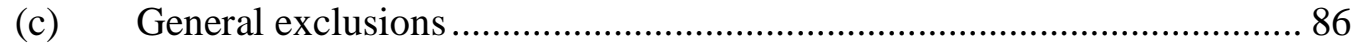

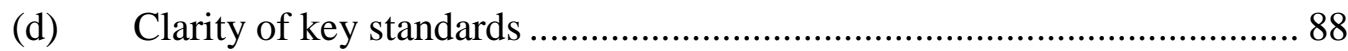

2 Promotion of consistency in investment arbitration ....................................... 88 
A The Natural Sovereign Temptation: Reduction of the Security of Investment

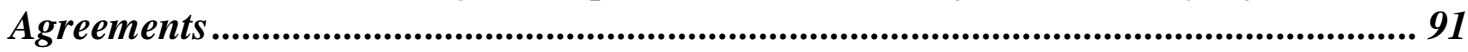

$1 \quad$ Rejection of arbitration: an inappropriate response ........................................ 91

(a) The withdrawal of Ecuador from ICSID ............................................... 92

(b) The effect of investment protection provisions in FTAs ......................... 95

2 The mistake of trying to narrow the scope of fundamental provisions............. 97

3 The inappropriate suggestion of a general exception provision ...................... 97

B The Need for a Partnership in International Investments ..................................... 100

$1 \quad$ Promoting good investment governance through transparency ..................... 100

2 Establishment of a unique administrative office …........................................ 104

3 Avoidance of litigation: adoption of an initial consultation with investors.... 105

$4 \quad$ Host states as true participants in the international investment process ....... 107

C Proposal of a Dynamic Harmonisation of International Investment Law..... 109

1 The all-embracing and innovative approach of the IISD ................................ 110

(a) Brief summary of the model of IIA suggested by the IISD ................... 110

(b) Analysis of what the model of IIA of the IISD does not consider.......... 111

2 New key issues on investor-state relationship ............................................ 112

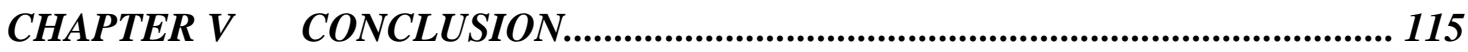

LIST OF ABBREVIATIONS AND ACRONYMS................................................... 117

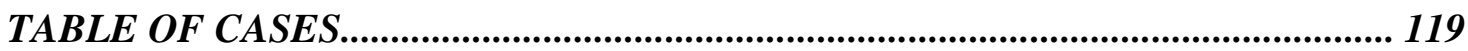

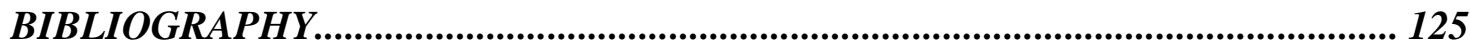




\section{ABSTRACT}

The subject of this dissertation is the relationship between the protection of foreign investors' investments under international investment law and the domestic law of host states. Two questions arise in this connection. First, is the promotion and protection of investments comprised in investment agreements compatible with states' domestic law? Second, public policies of host states may appear to be in contradiction with an increased international security of investments. When such a conflict is challenged by foreign investors, what are the consequences for both parties? In general, investments are transactions that are private in nature, whose aim is to generate a positive rate of return. Investments can have pervasive consequences on countries' welfare, including, for example, the consequences on sustainable development; the use and protection of natural resources; and employment, to name a few. It is the role of the governments to balance these sometimes conflicting public and private interests. As of today, it seems that the regime established according to investment treaties does not strike an appropriate balance between the various interests concerned. After a brief look at the legal framework protecting foreign investments, the conflict areas between investment treaty provisions and domestic public policies of host states are explored through an empirical analysis of some case studies and recent arbitrations. Finally, this dissertation holds that, at a substantive level, investment law is a part of international law. Thus it must be consistent with its norms and it has to be interpreted in accordance with customary rules of treaty interpretation. The dissertation concludes by suggesting the creation of a state-investor relationship and advocates, in part, the establishment of development objectives in investment treaties as well as the inclusion of rights and obligations for all parties involved.

\section{STATEMENT ON WORD LENGTH}

The text of this paper (excluding abstract, table of contents, table of cases, bibliography, list of abbreviations and footnotes) comprises approximately (33121) words. 


\section{CHAPTER I INTRODUCTION}

Private international investment is an increasingly important factor in the world economy. Both developed and developing countries benefit from a more effective allocation of resources and the integration of markets. Moreover, for a number of developing countries foreign investment represents a growing part of their external source of capital and technology. As of today, foreign direct investment (FDI) ${ }^{1}$ brings not only capital and technology to the host country, but also management expertise and access to new markets. Therefore, FDI is widely recognised as a major contributor to growth and development.

The establishment of businesses funded by foreign investors is one of the main factors promoting international capital movement. Thus, foreign direct investment had reached a bulk of US $\$ 1300$ billion in 2000, which corresponds to an impressive increase since 1970 , when this activity represented only US $\$ 12$ billion. ${ }^{2}$

If a long-term analysis shows a strong development of international investments, the recent period is however marked by a reorientation: in 2003 the total of foreign direct investment had dropped by more than half compared with 2000 , to only US $\$ 559$ billion. ${ }^{3}$ Such a backward step is without a doubt partly temporary, ${ }^{4}$ or even a sign of maturity from the world economy. Nevertheless, the reduction seems at the very least abrupt and indicates certain fragility in international investment.

A strong legal protection of foreign investments, preferably under consistent international rules, needs to exist. This is particularly so in a situation of economic instability, where investors seek stable management conditions.

\footnotetext{
${ }^{1}$ According to the terminology of the United Nations Conference on Trade and Development (UNCTAD) Foreign Direct Investment (FDI) is of a certain term and aims to establish control of a corporate body. The UNCTAD is a permanent intergovernmental body and is the principal organ of the United Nations General Assembly dealing with trade, investment and development. It was established in 1964. See: http://www.unctad.org/Templates/StartPage.asp?intItemID=2068 (last accessed 21 November 2008).

${ }^{2}$ UNCTAD World Investment Report 2004. The Shift Towards Services (United Nations Publications, New York and Geneva 2004) 367.

${ }^{3}$ Ibid.

${ }^{4}$ WTO International Trade Statistics 2003 (WTO Publications, Geneva, 2003) 167. The WTO stated a simultaneous decrease of world exports, their value went from $125 \%$ in 2000 to $120 \%$ in 2001 (100\%: in 1995).
} 
Therefore, it appears useful that a system protecting foreign investments has grown up thanks to international investment law. Indeed, host states are bound by international rules aiming to protect foreign investors from political risks. A good application of international rules can generally be ensured, at the initiative of investors, by international arbitration tribunals. Thus, the state finds its action subject to external control. Furthermore, the scope of international investment law has moved in a favourable way for investors because at this stage, it includes the full range of public action.

If this fact is reassuring for investors and would even be conducive to stabilising investments flows, such strong protection can however have an equivocal impact on the definition and administration of public policies of host states. ${ }^{5}$ Indeed, from now on, all the normative, administrative and judicial activities affecting the interests of foreign investors as well as those involving their capital seem to concern international investment law.

Aspects of both public and private international law define international investment law. On the one hand, states are subject to the rules of this unique class of international public law. On the other hand, the legal framework governing foreign investments benefits multinational enterprises which are subjects of the private international sphere. ${ }^{6}$

International investment agreements (IIAs) ${ }^{7}$ are usually identified as having a positive impact on development. Theoretically, the possibility of increased investment disputes brought about by the expanding network of IIAs may motivate host countries to improve domestic administrative practices and laws in order to avoid future disputes.

\footnotetext{
${ }^{5}$ Charles Oman Quelles Politiques pour Attirer les Investissements Directs Etrangers? - Une Etude de la Concurrence entre Gouvernements (OCDE, Paris, 2000) 103.

${ }^{6}$ Omar E García-Bolívar International Law on Foreign Investment at a Crossroads: the Need to Reform (2008). Paper available at: http://works.bepress.com/cgi/viewcontent.cgi?article=1002\&context=omar_garcia_bolivar (last accessed 04 February 2009) 1.

${ }^{7}$ The term International Investment Agreement (IIA) refers to all bilateral and multilateral investment treaties as well as to all other agreements containing comparable provisions signed between two or more countries to protect investments made by investors of one country (home state) in the other country (host state).
} 
Thus and according to the United Nations Conference on Trade and Development (UNCTAD): ${ }^{8}$

IIAs are important not only because of their potential international impact in terms of attracting foreign direct investment or sending positive signals to foreign investors. Equally significant are promotion of transparency, due process and strict application of the rule of law, which are the best means of avoiding investment disputes.

One of the critical challenges when negotiating IIAs is to try to achieve a balance between the need to provide a predictable and transparent FDI policy framework in which private firms can pursue their corporate objectives on the one hand, and the need to retain the national policy space that is needed to implement national development objectives on the other. ${ }^{9}$

Nevertheless, how a given IIA strikes this balance is often unclear on its face, and conflicts arise out of the growing application of IIA provisions on how they might regulate governments' policy making ability. The regulatory discretion of the sovereign states is challenged more and more by foreign investors. Indeed, an increasing number of investor-state cases contain new regulatory measures as the basis of their claim. The increased protection provided by states to foreign investors, including provisions to protect against the ratification of discriminatory measures, for example, will certainly affect the discretion of host governments to regulate in the public interest. ${ }^{10}$

Yet, according to the good governance perspective, it is important for every state hosting foreign investments to be aware of the international legal risks linked to the public policies implemented in its territory. Political and administrative authorities of host states must draw lessons not only about their room for maneuverability (which is therefore reduced) but also about the possible need to reorganise their relationship with investors.

\footnotetext{
${ }^{8}$ UNCTAD Investor-State Dispute Settlement and Impact on Investment Rule Making (United Nations Publications, New York and Geneva, 2008) 93.

${ }^{9} \mathrm{~J}$ Weber Existing Proposals on Bilateral and Multilateral Investment Agreements and Practices Towards Codes of Conduct on TNCs and Governments With Respect to FDI in UNCTAD-Civil Society Dialogue on Selected Development Issues Being Addressed by the United-nations System (Papers Prepared in Support of the Issues Discussed, Geneva, 2002) 31.

${ }^{10}$ Howard Mann Investment Agreements and the Regulatory State: Can Exceptions Clauses Create a Safe Haven for Governments? (Issues in International Investment Law, Background Papers for the Developing Country Investment Negotiator's Forum, IISD, Singapore, 2007) 2.
} 
In order to highlight the relationship between the protection of foreign investments under international investment law and the domestic law of host states, the present study adopts a combined methodology. This dissertation is primarily based on a legal analysis in order to identify the current state of international investment law. This analysis will be confirmed by empirical factors from the socio-economic situation. The study also takes into consideration political and administrative analysis in order to underline the key issues linked to the evolution in the security of international foreign investments in public management. Therefore, the dissertation is divided into three chapters that treat distinct but interrelated issues.

Chapter II explores the nature and the evolution of international investment law. The methodological study described above will allow the assessment of the meaning and scope of rules existing under the security of international investments. The purpose of this chapter is not to provide an in-depth evolution and historical background of foreign investment law, but it aims to briefly highlight the legal framework protecting foreign investments.

In Chapter III, the dissertation will attempt to identify the impact of increased protection of foreign investments through investment treaties on the regulatory power of host states and, in particular, on the public policies that are most affected. The potential conflicts between investment treaty provisions and domestic public policies of host states are explored through an empirical analysis of some case studies and recent arbitrations. While the benefits of international investment are generally recognised, there are concerns that these provisions are offering more and more guarantees to international investors at the expense of the domestic regulatory power of the state. On the one hand, the independent management of domestic economic affairs is desired; on the other, it is recognised that a large measure of participation in the international economy serves the general welfare. This dilemma lies at the heart of the tensions which sometimes arise between international investors and the governments of both host countries and investor countries.

Finally, Chapter IV will reflect on the foregoing analysis in preparation for analysing a new way to manage relationships between host states and investors. It is indeed essential to promote mutual understanding between private international investors 
and governments on the fundamental issues affecting their relationship. In addition, this dissertation advocates for the establishment of development objectives in investment treaties as well as the inclusion of rights and obligations for all parties involved. Accordingly and on the basis of the model of an International Agreement on Investment for Sustainable Development developed by the International Institute for Sustainable Development (IISD), ${ }^{11}$ this dissertation supports the recognition of a right to the security of foreign investments which could be included in the preamble of international investment agreements under the condition to respect some fundamental international rules.

${ }^{11}$ International Institute for Sustainable Development (IISD) at: http://www.iisd.org/ (last accessed 11 May 2009). 


\section{CHAPTER II A BRIEF HISTORICAL REVIEW OF THE EVOLUTION OF THE CONCEPT OF SECURITY OF FOREIGN INVESTORS UNDER INTERNATIONAL INVESTMENT LAW}

The singularity of the current IIA network results from an ancient historical evolution. ${ }^{12}$ Former to the twentieth century, diplomatic protection and claims commissions were the primary means to enforce international standards of foreign investment and investor protection. ${ }^{13}$ The globalisation of the world economy introduced some limits to the diplomatic model of protection. In particular debates around the customary international law minimum standard of treatment to be accorded to foreign investors and investments arose between capital exporting and importing states. ${ }^{14}$ In the post Second World War (WWII) era, the contemporary investment treaty framework was developed. The historical development of international investment law is a fundamental step to take into consideration in order to better understand contemporary controversies in this area of law.

While in the course of the 1960s and 1970s, international investment litigation remained (because of the absence of legal tools) relatively uncommon, the massive emergence of bilateral conventions for the protection and promotion of investments since then has resulted in a massive increase in arbitrations. Whereas the International Centre for Settlement of Investment Disputes (ICSID) registered only 25 cases from 1972 to 1990, 60 cases were resolved under the auspices of the Centre in the following fourteen years. As of September 2009, 122 cases were pending. ${ }^{15}$ The ICSID is an autonomous international institution established under the Convention on the Settlement of Investment Disputes between States and Nationals of Other States ${ }^{16}$ with over one hundred and forty member states. The Convention sets out the mandate, organisation and core function of ICSID. The primary purpose of ICSID is to provide facilities for the conciliation and

\footnotetext{
12 Andrew Newcombe and Lluís Paradell Law and Practice of Investment Treaties. Standards of Treatments (Kluwer Law International, 2009) 1.

${ }^{13}$ Ibid, 8-10.

${ }^{14}$ Ibid, 11-18.

${ }^{15}$ Statistics published by the ICSID. Available at: http://icsid.worldbank.org/ICSID/FrontServlet (last accessed 25 September 2009).

${ }^{16}$ Convention on the Settlement of Investment Disputes between Sates and Nationals of other States (ICSID Convention) (signed 18 March 1965, entered into force 14 October 1966) 575 UNTS 159. ICSID See http://icsid.worldbank.org/ICSID/Index.jsp (last accessed 8 September 2008).
} 
arbitration of international investment disputes. The ICSID Convention is a multilateral treaty formulated by the Executive Directors of the International Bank for Reconstruction and Development (the World Bank).

The cumulative total of all known cases brought under bilateral, regional ${ }^{17}$ or plurilateral ${ }^{18}$ agreements that contain investment clauses or IIAs, is now $298 .{ }^{19}$ Well over half (92) of the 160 known claims were filed within the past three years. Virtually none of them were initiated by governments. In view of this recent surge, it is not surprising that the majority of investment treaty arbitration proceedings are still pending before tribunals. Due to the fact that many claims are still pending, some uncertainty surrounds the meaning of key treaty provisions. "All of this means that governments need to be very careful when negotiating investment treaties", ${ }^{20}$ said Karl P Sauvant, Director of the UNCTAD Division on Investment, Technology and Enterprise Development.

Such a massive rise in the number of disputes under the ICSID indicates the increased importance of international investment law. It is obvious that foreign investors would not have resorted to arbitration tribunals in such increasing numbers if they had not thought that they would gain justice. Thus, almost exclusively, private parties have used international tribunals as an alternative. Host states, in general, prefer to leave the disputes to their own domestic justice system.

We might say that international investment law has evolved favourably from a foreign investor perspective. Furthermore, investment law norms, at least the way in which they are sanctioned by the courts, have received recognition and enforcement by host states.

This Chapter is divided into three parts. The first part explores the origins and developments of international treaty law from the 1920s, setting the background for the

\footnotetext{
${ }^{17}$ For example, the North American Free Trade Agreement between the Government of Canada, the Government of Mexico and the Government of the United States (NAFTA) (adopted 17 December 1992, entered into force 1 January 1994) 32 ILM 289.

${ }^{18}$ For example, the Energy Charter Treaty (ECT) (signed 17 December 1964, entered into force 16 April 1998) 2080 UNTS 100.

${ }^{19}$ Statistics published by the ICSID, above n 14. International investment disputes can also arise from contracts between investors and governments. A number of such disputes are, or have been, before ICSID but are not included in its data.

20 UNCTAD International Investment Disputes on the Rise - Occasional Note (UNCTAD/WEB/ITE/ITT/2004/2, 29 November 2004) 1.
} 
second part, which discusses the role played by arbitral tribunals in shaping the interpretation of the main standards of treatment of foreign investors. The last part deals with the current structure of IIAs and how an increased protection of investors is now to be observed.

\section{A A Slow Evolution of Law: An Increasing Security with Uncertain Limits}

\section{$1 \quad$ A basic protection of investment and investors}

The corpus of principles and rules of international investment law was, at the beginning of its development, relatively limited in scale and range. Indeed, from the 1920s, the courts called to rule on the first cases could, in the absence of texts, only use general principles of international law and in particular those concerning the law of aliens which were necessarily unsuited to such an application, as well as not being very concrete or well-developed. Under the terms of these principles every sovereign had to grant adequate treatment and protection to the subjects of its counterparts. Concerning foreign investments, the courts could only draw the principle that the host state is bound to give up any measure pointedly discriminatory and outrageous. ${ }^{21}$

Indeed, in the Neer case, Mr Neer (a United States national) was working in a mine in Mexico when he was killed by a group of armed men. ${ }^{22}$ When the US presented a claim against Mexico, the claim was rejected on the grounds that the tribunal could not prove that the lack of conscientiousness on the part of Mexican authorities to apprehend the perpetrators was the reason for the death of $\mathrm{Mr} \mathrm{Neer}^{23}$

International disputes of the 1920s and 1930s reflect a certain tension between national autonomy and international controls. In his separate opinion, the judge Fred $\mathrm{K}$ Nielsen emphasised this tension. Nielsen clearly pointed out that in international law the scope of sovereign rights in relation to matters subject to domestic regulations must conform to the constraints imposed by such sovereignty. ${ }^{24} \mathrm{He}$ also explains that a failure

\footnotetext{
${ }^{21}$ LFH Neer \& Pauline Neer (USA) v United Mexican States US-Mexico Claims Commission (1926) IV RIAA 60 , paras 4 and 5 .

${ }^{22}$ LFH Neer \& Pauline Neer (USA) v United Mexican States, above n 21, para 1.

${ }^{23}$ Ibid, paras 5 and 6.

${ }^{24}$ LFH Neer \& Pauline Neer (USA) v United Mexican States, above n 21, Separate Opinion, 64.
} 
to do so can result in the recognition of international delinquency. ${ }^{25}$ A need for such requirement is no less favourable than that required by the regulations of international law. ${ }^{26}$ Such a scenario is sustained by the notion that international law requires states to treat 'aliens' in accordance with minimum international standards. ${ }^{27}$ This is undeniably supported by the Neer claim, resolved by the Mexican-United States General Claims Commission: $:^{28}$

The propriety of governmental acts should be put to the test of international standards... the treatment of an alien, in order to constitute an international delinquency, should amount to an outrage, to bad faith, to wilful neglect of duty, or to an insufficiency of governmental action so far short of international standards that every reasonable and impartial man would readily recognise its insufficiency.

Following WWII, states allowed international investment law to develop only slowly and partially. There was no adoption of a multilateral investment instrument or a bilateral development of rules specific to investment, as was the case for trade. ${ }^{29}$ Thus, old agreements from $19^{\text {th }}$ century known as "FCN" (Friendship-Commerce-Navigation) agreements are still in effect today or agreements concluded on the same model of the years $1950-1960,{ }^{30}$ which had during long years to be used as a substitute with more adapted rules. Typically, such agreements, in addition to the reciprocal obligation of "perpetual peace and friendship", simply required that private activities be accorded

\footnotetext{
${ }^{25}$ Ibid, 64.

${ }^{26}$ Ibid, 64.

${ }^{27}$ Surya P Subedi International Investment Law Reconciling Policy and Principle (Hart Publishing, Oxford and Portland, Oregon, 2008) 118.

${ }^{28}$ LFH Neer \& Pauline Neer (USA) v United Mexican States, above n 21, para 4.

${ }^{29}$ General Agreement on Tariffs and Trade (GATT) (30 October 1947) 55 UNTS 194. The GATT is only a component of the World Trade Organisation (WTO) which was meant to be created under the Havana Charter but the Charter failed to come into effect. The Charter should have contained rules relating to international investment. Only the GATT remained by temporary application from 1947 and until 1995 when it has been inserted to the World Trade Organisation System by the Marrakech agreements: General Agreement on Tariffs and Trade: Multilateral Negotiations: Final Act Embodying the Results of the Uruguay Round of Trade Negotiations (WTO Agreement) (signed 15 April 1994, entered into force 1 January 1995) 33 ILM 1126.

${ }^{30}$ Treaty of Friendship, Commerce and Navigation between the United States and Nicaragua (21 January 1956) (quoted in: Military and Paramilitary Activities in and against Nicaragua (Nicaragua $v$ United States) (Jurisdiction and Admissibility) [1986] ICJ Rep 392); Treaty of Amity, Economic Relations and Consular Rights between the United States of America and the Islamic Republic of Iran (15 August 1955) 8 UST 899 (entered into force 16 June 1957) ('the Treaty') (quoted in: Oil Platforms Case (Islamic Republic of Iran v United States of America) [2003] (Merits) ICJ Rep 161).
} 
most-favoured nation treatment, as well as including an obligation to treat foreigners and their property in accordance with national law. ${ }^{31}$

The General Assembly of the United Nations finally took the initiative to state a certain number of more concrete principles for the protection of foreign investments. In particular, the General Assembly voted with a very large majority that any use by states of the right of expropriation had to be exercised with due respect to certain conditions of international law, and in particular that an expropriation be followed by appropriate compensation: ${ }^{32}$

\begin{abstract}
Nationalisation, expropriation or requisitioning shall be based on grounds or reasons of public utility, security or the national interest which are recognised as overriding purely individual or private interests, both domestic and foreign. In such cases, the owner shall be paid appropriate compensation, in accordance with the rules in force in the State taking such measures in the exercise of its sovereignty and in accordance with international law. In any case, where the question of compensation gives rise to a controversy, the national jurisdiction of the State taking such measures shall be exhausted. However, upon agreement by sovereign States and other parties concerned, settlement of the dispute should be made through arbitration or international adjudication.
\end{abstract}

The General Assembly does not have, under the United Nations Charter, ${ }^{33}$ a capacity to promulgate binding international law. ${ }^{34}$ Certain authors could see in the statement of states' right of expropriation an expression of opinio juris, one of the components of customary international law $^{35}$ which binds the states even in the absence

\footnotetext{
${ }^{31}$ Treaty of Friendship, Commerce and Navigation between the United States of America and Liberia (21 October 1962) Article III.

${ }^{32}$ UNGA Resolution 1803 (XVII) on Permanent Sovereignty Over Natural Resources (14 December 1962) $\mathrm{A} / \mathrm{RES} / 1803$, para 4. Certain authors support that the term "suitable" is equivalent to a compensation standard less demanding than the Hull Rule which stated a "prompt, adequate and effective" compensation, for example Andrew Guzman Explaining the Popularity of Bilateral Investment Treaties: Why LDCs Sign Treaties That Hurt Them (Jean Monnet Centre Working Papers, New York University School of Law, 1997). Available at: http://www.jeanmonnetprogram.org/papers/97/97-12.html (last accessed September 2008). The US government (the author of the Hull Rule) has on the contrary stated the similarity of the two standards, e.g. the official declaration quoted in: Louis Henkin, Richard Pugh, Oscar Schachter and Hans Smit International Law: Cases and Materials (3ed, West Publishing, St Paul, 1988) 1063.

${ }^{33}$ Charter of the United Nations (UN Charter) (signed 26 June 1945, entered into force 24 October 1945) 59 Stat 1031: TS 993; 3 Bevans 1153.

${ }_{35}^{34}$ Article 10 of the Charter grants the Assembly a power of advice.

${ }^{35}$ See article 38 para $1 \mathrm{~b}$ ) of the Statute of the International Court of Justice (ICJ Statute) (signed 26 June 1945, entered into force 24 October 1945) 3 Bevans 1179; 59 Stat 1055; TS No 993. Available at http://www.icj-cij.org (accessed 23 September 2008).
} 
of a convention. ${ }^{36}$ In association with the compounding practice that the states followed, the resolution was considered by pre-eminent observers as reflecting the state of law. ${ }^{37}$ In addition, the Resolution stated that the state had control over the admission of foreign investment by means of authorisation, restriction or prohibition. ${ }^{38}$ However, once granted, national and international law shall govern foreign investment. ${ }^{39}$

Following the admission of the recently independent states to the United Nations, the 1970s saw a collapse of the consensus concerning the international customary protection of foreign investments. ${ }^{40}$ These states, taking advantage of their majority at the General Assembly of the United Nations, voted several resolutions under the terms of which no international legal provision could limit their right to expropriate. ${ }^{41}$

It would have meant, in practice, that the compensation for expropriation could be fixed according to criteria chosen by host states, or even totally eliminated. From a legal point of view, the pre-existent customary international rule that compelled recently independent states to adequately compensate the investor could not however be rejected in this way. Customary international law is binding on states even if it was developed before a state came into existence and the state did not contribute to its development. Indeed, given the conservative nature of international law, the absence of opinio juris in some states, as UN resolutions might suggest, does not lead to the immediate collapse to a customary rule. ${ }^{42}$ In addition, the resolutions at issue were voted against by industrialised states. Therefore, the resolutions could probably not found the suppression

\footnotetext{
${ }^{36}$ Texaco Overseas Petroleum Co v Libyan Arab Republic (1978) (Award) 17 ILM 3 (Ad Hoc Arb) para 27. See Dominique Carreau and Patrick Juilliard Droit International Economique (3ed, Dalloz, Paris 2007) 1163.

${ }^{37}$ Texaco Overseas Petroleum Co v Libyan Arab Republic, above n 36, para 90.

${ }^{38}$ UNGA Resolution 1803 (XVII) on Permanent Sovereignty Over Natural Resources, above n 25, para 2. See Andrew Newcombe and Lluís Paradell Law and Practice of Investment Treaties. Standards of Treatments (Kluwer Law International, 2009) Chapter 1, paras 1.20 and 26.

${ }^{39}$ UNGA Resolution 1803 (XVII) on Permanent Sovereignty Over Natural Resources, above n 38, para 3.

${ }^{40} \mathrm{~S}$ K B Asante "Droit International et Investissements" in Bedjaoui Mohammed Droit International. Bilan et Perspectives (Pedone/UNESCO, Paris, 1991) 711-719.

${ }^{41}$ For example see UNGA Resolution 3201 (S-VI) Declaration on the Establishment of a New International Economic Order (1 May 1974) A/RES/3201; UNGA Resolution 3202 (S-VI) Programme of Action on the Establishment of a New International Order (1 May 1974) A/RES/3202 and UNGA Resolution 3281 (XXIX) Containing the Charter of Economic Rights and Duties of States (12 December 1974) A/RES/29/3281, Article 2, para 2.

${ }^{42}$ Kuweit Government v American Independent Oil Company (Aminoil) (1982) (Award) 21 ILM 976 (Ad Hoc Arb) 1024, para 90. See also Bruno Simma and Alfred Verdross Universelles Völkerrecht: Theorie und Praxis (3ed, Duncker \& Humblot, Berlin, 1984) paras 572 and 574.
} 
of the rule, at least where North-South relationships were concerned since the rule had been established by the international community as a whole. ${ }^{43}$ Regardless of the legal position, however, at this stage the security of foreign investments seemed in practice to be seriously threatened.

\section{Development of a large BITs' network}

However, economic pragmatism ended up by prevailing on both sides ${ }^{44}$ and made it possible to develop a network of bilateral conventions for the protection and promotion of investments. Developing countries recognised the benefit of attracting foreign investments by the creation of a protective body of rules. There are about 2500 conventions in force today ${ }^{45}$ undoubtedly binding states' parties. ${ }^{46}$ The signature of the first BIT (Bilateral International Treaty) between Germany and Pakistan in 1959 did not lead to a boom of BITs (despite the embracement by European states of the BIT model). Until 1991, only 400 BITs had been concluded worldwide. ${ }^{47}$ The number of BITs concluded increased significantly during the 1990s. By contrast with the year 1996, when about 1000 BITs existed worldwide, today more than 2500 BITs have been brought into life, linking more than 170 countries. An academic author has characterised the exponential rise of BITs as a "treatification of international investment law." ${ }^{48}$ BITs are generally signed between a developed and a developing country. Such treaties generally

\footnotetext{
${ }^{43}$ Texaco Overseas Petroleum Co v Libyan Arab Republic, above n 36, para 80. See also the Declaration of the US representative at the VIth Commission of United Nations General Assembly (11 November 1977) 72 AJIL 377, 378.

${ }^{44}$ See Godfrey Bahiigwa "The Impact of Trade and Investment Policies on the Environment: Uganda's Fisheries Industry" in OECD Assessing the Environmental Effects of Trade Liberalisation Agreements (OECD, Paris, 2000) 187.

${ }^{45}$ The United Nations Conference on Trade and Development (UNCTAD) maintains a compendium of international investment agreements, available at www.unctad.org (accessed 18 October 2008). BITs are documented at http://www.unctadxi.org/templates/DocSearch 779.aspx (accessed 18 October 2008) where the texts of more than 2,500 BITs can also be found.

${ }^{46}$ Article 26 of the Vienna Convention on the Law of Treaties (VCLT) 1155 UNTS 331 (signed 23 May 1969, entered into force 27 January 1980). See Gabčíkovo-Nagymaros Project (Hungary v Slovakia) (Judgement) [1997] ICJ Rep 3, para 46.

${ }^{47}$ United Nations Centre on Transnational Corporations (UNCTC) and International Chamber of Commerce (ICC) Bilateral Investment Treaties 1959-1991 UN Doc ST/CTC/136 (New York, 1992) Annex.

${ }^{48}$ Jeswald W Salacuse "The Treatification of International Investment Law: A Victory of Form over Life? A crossroads crossed?” (2006) 3 TDM 1, 3 .
} 
bear common characteristics. BITs indicate the rights granted to investors, such as the scope of application to investments and investors, the kind of investments that are covered, when coverage begins and ends, and in case of infringement how dispute settlement works. ${ }^{49}$ Bilateral conventions which form a dense network today contributed to the appearance not only of one real protection on the field but also of a homogeneous theory of this area of law, and this in particular because of recurrent standards of treatment:

An obligation of fair and equitable treatment (FET) of investment;

An obligation to guarantee a full protection and security of investment;

A clause providing for national treatment of the investment and the foreign investor;

A clause providing most-favoured nation (MFN) treatment to the investment;

A prohibition on the expropriation of the investment without prompt, adequate and effective compensation.

Despite the high number of conventions it is possible to mention these common normative provisions contained in bilateral investments treaties because they are based on a "model" of convention widely used in negotiations by capital-exporting states and elaborated by the OECD. ${ }^{50}$ However certain differences remain. In particular, bilateral conventions promulgated by the United-States provide that the obligation of national treatment applies from the pre-establishment phase onwards.

\footnotetext{
49 Alexandra N Diehl "Tracing a Success Story or "The Baby Boom of BITs" Characteristics and Particularities of the Tight Net of Bilateral Investment Treaties Existing Today" in August Reinisch and Christina Knahr International Investment Law in context (Eleven International Publishing, The Netherlands, 2008) 8.

${ }^{50}$ Organisation for Economic Co-operation and Development (OECD) Draft Convention on the Protection of Foreign Property and Resolution of the Council of the OECD on the Draft Convention (1967) 7 ILM 117.
} 
According to a literal reading of these provisions, however, their scope remains limited. The terminology is indeed vague and thus creates a margin of interpretation. Nevertheless the intention of the parties at the time of the negotiations was a restricted meaning of the protective clauses for the investor ${ }^{51}$ and the principles of interpretation of international law would require any such special meaning to be taken into account at the time of the interpretation of the texts. ${ }^{52}$ Moreover, in traditional international law, restrictions on sovereignty are not presumed. ${ }^{53}$ An "uncertainty" exists only when all methods of interpretation allowed by international law have been previously exhausted. However, pro-states treaty interpretations remain very few in comparison with proinvestor ones. Recent case law regarding the concept of fair and equitable treatment suggests that state action affecting investors' legitimate expectations and legal and business stability constitutes a breach of the fair and equitable treatment standard. The analysis about legitimate expectations is notably reflected in the awards in CMS $v$ Argentine Republic ${ }^{54}$ and Técnicas Medioambientos Tecmed, SA (Tecmed) v United Mexican States. ${ }^{55}$ The tribunal in CMS based its definition of the standard on the stability of the legal and business environment. ${ }^{56}$ In particular it stressed that "fair and equitable treatment is inseparable from stability and predictability." ${ }^{57}$ In the light of the requirement of stability and predictability, the tribunal in Tecmed held that fair and equitable treatment meant that the host state would: ${ }^{58}$

act in a consistent manner, free from ambiguity and totally transparently in its relations with the foreign investor, so that [the investor] may know beforehand any and all rules and regulations that will govern its investments, as well as the goals of the relevant policies and administrative practices or directives, to be able to plan its investments and comply with such regulations.

In finding Argentina in breach of the fair and equitable treatment standard, the CMS tribunal also observed that "the measures that are complained of did in fact entirely

\footnotetext{
${ }^{51}$ See NAFTA Free Trade Commission Clarifications Related to NAFTA Chapter 11 (31 July 2001). Available at http://www.worldtradelaw.net/nafta/chap11interp.pdf (last accessed 20 May 2009) 2.

${ }^{52}$ See Vienna Convention on the Law of Treaties (VCLT), above n 46, Article 31, para 4.

${ }^{53}$ The Case SS "Lotus" (France v Turkey) (Judgement) [1927] PCIJ (Series A, No 10) 1.

${ }^{54}$ CMS Gas Transmission Co v Republic of Argentina (2003) (Jurisdiction) 42 ILM 788 (ICSID).

${ }^{55}$ Técnicas Medioambientales Tecmed SA v United Mexican States (2004) (Award) 43 ILM 133 (ICSID $(\mathrm{AF})$ ).

${ }^{56}$ CMS Gas Transmission Co v Republic of Argentina, above n 54, para 274.

${ }^{57}$ Ibid, para 276.

${ }^{58}$ Técnicas Medioambientales Tecmed SA v United Mexican States, above n 55, para 98.
} 
transform and alter the legal and business environment under which the investment was decided and made." 59 The tribunal acknowledged that a legal framework could legitimately evolve to adapt to changing circumstances, but went on to state that the framework could not be "dispensed with altogether when specific commitments to the contrary have been made." 60

In these cases, unfair and inequitable treatment is equated with any state conduct that departs from the expectations investors may derive from conditions at the time they make their investment. One could argue that because arbitral tribunals held in both cases that a measure taken by the host state was not consistent with the fair and equitable treatment, an allegation of the breach of this standard of treatment regarding legitimate expectations of investors will always be found. However, consistency reflected in the jurisprudence of arbitral awards does not necessary mean there exits a definitive rule of law that any claim made in this respect will be found in favour of foreign investors. It must also be considered that when the tribunal applies the above principle of legitimate expectations to inconsistent international obligations, it might result in accentuating the application of this notion to non-investment obligations at the time of the establishment of the investment in the host country. ${ }^{61}$

The BIT phenomenon, designed to ease barriers to FDI and generate more FDI inflows, has proved to be successful in that purpose: the acceleration of the number of ratified BITs and the increase in the rates of FDI converge. ${ }^{62}$ From only less than $\$ 100$ billion in 1980, the world's stock of FDI now stands at almost $\$ 1600$ billion. ${ }^{63}$ In addition, foreign investors benefit from legal rights granted by the adoption of BITs. Despite the restriction it might impose on the sovereign sphere of control of host governments, states keep signing BITs because developed countries consider BITs as a way to protect the interests of their multinational enterprises (MNEs) whereas developing countries see BITs as necessary to attract private capital from abroad. Therefore,

\footnotetext{
${ }^{59}$ CMS Gas Transmission Co v Republic of Argentina, above n 54, para 275.

${ }^{60}$ Ibid, para 277.

${ }^{61}$ Moshe Hirsch "Interactions between Investment and Non-Investment Obligations in International Investment Law" in Peter Muchlinski, Federico Ortino and Christoph Schreuer (eds) The Oxford Handbook of International Investment Law (Oxford University Press, New York, 2008) 173.

${ }^{62}$ UNCTAD World Investment Report 2009 (United Nations Publications, New York and Geneva, 2009) 3 4. ${ }^{63}$ Ibid.
} 
governments from both developed and developing countries seek economic liberalism by freeing the international flow of goods, services and investment. ${ }^{64}$

Some tribunals find BITs to be instruments sustaining investor protection. In this light, a tribunal in Siemens $A G v$ The Argentine Republic held: ${ }^{65}$

The Tribunal shall be guided by the purpose of the Treaty as expressed in its title and preamble. It is a treaty "to protect" and "to promote" investments... It is to create favourable conditions for investments and to stimulate private initiative.

Hence, uncertainties as to how to resolve unclear treaty provisions should be resolved in favour of foreign investors. ${ }^{66}$ Nevertheless recent decisions have rejected such an approach in providing states more margins of appreciation ${ }^{67}$ as well as considering that: ${ }^{68}$

\begin{abstract}
A balanced interpretation is needed, taking into account both State sovereignty and the State's responsibility to create an adapted and evolutionary framework for the development of economic activities, and the necessity to protect foreign investment and its continuing flow', thus rejecting a one-sided interpretation either in favour of foreign investors or in favour of host states.
\end{abstract}

In a dispute were it was respondent, the United States argued that: ${ }^{69}$

a doctrine of restrictive interpretation should be applied in investor states disputes. In other words, wherever there is any ambiguity in clauses granting jurisdiction over disputes concerning states and private persons, such ambiguity is always to be resolved in favour of maintaining state sovereignty.

The obvious and growing role of BITs in the world political economy is therefore acknowledged. The areas of both monetary policy and trade are coordinated through coherent multilateral regimes. In contrast, the governance of FDI is highly decentralised. A limited regulatory framework on investment has been developed in the form of the

\footnotetext{
${ }^{64} \mathrm{~K}$ J Vandevelde "A brief History of International Investment Agreements" (2005) 12 UCDJILP 162.

65 Siemens AGv The Argentine Republic (Decision on Jurisdiction) (3 August 2004) (ICSID Case No. $\mathrm{ARB} / 02 / 8)$ para 81.

${ }^{66}$ SGS Société Générale de Surveillance S.A v The Republic of the Philippines (ICSID Case No. ARB/02/6) (29 January 2004) para 116.

${ }^{67}$ Saluka Investments BV (The Netherlands) v Czech Republic (2006) (Partial Award) (UNCITRAL) para 304.

${ }^{68}$ El Paso Energy International Company v Argentine Republic (2006) (Decision on Jurisdiction) (ICSID Case No. ARB/03/15) para 70.

${ }^{69}$ Methanex Corp v United States of America (2005) 44 ILM 1345 (NAFTA/UNCITRAL) para 103.
} 
Trade Related Investment Measures (TRIMS) ${ }^{70}$ and General Agreement on Trade in Services $(\mathrm{GATS})^{71}$ under the auspices of the World Trade Organisation (WTO). ${ }^{72}$

(a) The collapse of the Multilateral Agreement on Investment

Failed negotiations among the member states of the OECD from 1995 to 1998 towards the Multilateral Agreement on Investment (MAI) ${ }^{73}$ need to be studied. It is not the goal of the present dissertation to comment extensively on this particular issue of international investment law. Reference is made only for the purpose of identifying the issues at stake and what conclusions can be drawn from such a failure.

In May 1995, the negotiations for a Multilateral Agreement on Investment between the 29 Member states of the OECD started. One can identify three factors leading to the decision to study the possibility of such an agreement: a rapid growth in investment flows by the early 1990s, the trend towards unilateral liberalisation of national restrictions on foreign investment, and the absence of a comprehensive international investment framework agreement. ${ }^{74}$ The analysis of the failure of the MAI is based on the last version of the agreement that was produced on 24 April 1998 and released by the OECD on the Internet. ${ }^{75}$ The draft contains 12 chapters and encompasses 145 pages. Despite its length, the majority of clauses in the draft text deal with recognised areas in investment liberalisation, investment protection and dispute settlement. ${ }^{76}$ The main aim of this agreement was to establish high standards for investment protection of a worldwide application. Such a high investment protection was to be reached among other measures by a broad definition of investor and investment in

\footnotetext{
${ }^{70}$ Agreement on Trade-Related Investment Measures (TRIMS) (signed 15 April 1994) 1868 UNTS 186.

${ }^{71}$ General Agreement on Trade in Services (GATS) (15 April 1994) 1869 UNTS 299.

${ }^{72}$ World Trade Organisation, above n 29.

${ }^{73}$ Multilateral Agreement on Investment (MAI) (Final Unadopted Negotiating Draft, OECD, 22 April 1998 DAFFE/MAI (98)) 7 REV 1.

${ }^{74}$ OECD A Multilateral Agreement on Investment: Report by the Committee on International Investment and Multinational Enterprises (CIME) and the Committee on Capital Movements and Invisible Transactions (CMIT) (Document OECD/GD (95)65, Paris, 1995) Chapter 1.

${ }^{75}$ OECD MAI Negotiating Text (24 April 1998) (OECD Directorate for Financial, Fiscal and Enterprise Affairs, Paris, 1998).

${ }^{76}$ MAI, above n 73, 13-70.
} 
order to ensure a large scope of protection. ${ }^{77}$ Additionally, minimum standards of treatment such as national treatment ${ }^{78}$ and most-favoured-nation treatment ${ }^{79}$ were provided in order to achieve non-discrimination among national and foreign investors in combination with adequate compensation. ${ }^{80}$

The basic idea behind the MAI was that FDI is an engine for economic growth, and by the same token, "growth in FDI has been underpinned by widespread liberalisation". ${ }^{81}$ The MAI treaty thus had to: ${ }^{82}$

\footnotetext{
set clear, consistent, and transparent rules on liberalisation and investor protection, with dispute settlement, thereby underpinning the continued removal of barriers to market access and encouraging economic growth.
}

An examination of the key components of the MAI is necessary. Principles and standards contained in the MAI were to a large extent based on the provisions of the NAFTA agreement. Hence, regarding the scope of application, the MAI adopted an assetbased definition of investment. ${ }^{83} \mathrm{~A}$ standard of non-discrimination between foreign and domestic investor ${ }^{84}$ as well as the application of national and MFN treatment to both the pre- and post-admission phases of the investment process ${ }^{85}$ would have been imposed on its member states. Chapter IV of the draft MAI set out the investment protection provisions. In the event of expropriation of their investments, host states were required to provide foreign investors with compensation. ${ }^{86}$ The strong provisions on expropriation would cover direct as well as indirect expropriations. The category of indirect expropriation includes governmental measures "having equivalent effect" to a direct expropriation. ${ }^{87}$ No guidance is given within the MAI provisions as to whether normal regulatory changes that negatively affect the value of an investment would be covered within the concept of an indirect expropriation. Member states are required to provide fair

\footnotetext{
77 Above n 73, Annex 2, Article 1.

${ }^{78}$ Above n 73, Annex 3.

${ }^{79}$ Ibid.

${ }^{80}$ Above n 73, Annex 3, Article 5.

${ }^{81}$ Above n 73, 10.

${ }^{82}$ Ibid.

${ }^{83}$ Above $n$ 73, Chapter 2, Article 2.

${ }^{84}$ Above n 73, 13.

${ }^{85}$ Ibid.

${ }^{86}$ Above n 73, 57-58.

${ }^{87}$ Ibid.
} 
and equitable treatment and full protection and security while ensuring a minimum standard of treatment of that required by international law. ${ }^{88}$ Lastly, investor-state dispute settlement procedures are provided for. ${ }^{89}$

In 1997, the negotiations had to be extended for one year. Despite the extension, a suspension of six months occurred in April 1998, at the yearly meeting of the OECD Council, in order to "consult with civil society" and "take stock of the national situation." ${ }^{90}$ In October 1998, before negotiations could be resumed, France officially pulled out of the negotiations and was followed by many other countries that appeared to withdraw their support for the MAI. During the autumn of 1998 negotiations faded away.

Relatively low levels of transparency were reflected during the MAI negotiations. Three possible reasons can be identified. First of all, the interests of capital-exporting countries might have been promoted by the scope and application of the MAI to the detriment of capital-importing countries. ${ }^{91}$ Moreover, the OECD forum did not reflect a large variety of actors and states. As a matter of fact, capital-exporting states are the main OECD members. ${ }^{92}$ Finally, the negotiations process exposed tensions as to whether the MAI should reflect a United States or more modest European model. ${ }^{93}$ Thus, the failure of the MAI demonstrates that "there is no common ground concerning certain farreaching standards of investment protection." 94

(b) Increased participation of NGOs in investment arbitrations

Insufficient participatory opportunities for Non-Governmental Organisations (NGOs) must also be pointed out. The main reason for this was that the MAI negotiations had largely been conducted confidentially between the representatives of the 29 member states of the OECD. A large variety of NGOs became extremely concerned once the negotiating text was released on the Internet. Soon, a bewildering number of around 600 NGOs involving 70 countries were involved in the MAI campaign. The draft treaty was

${ }^{88}$ Ibid.

${ }^{89}$ Above n 73, 63-76.

90 TUAC 1998: Ministerial Statement on the MAI, TUAC Note, 28 April.

${ }^{91}$ Alexandra N Diehl, above n 49, 21.

92 Ibid.

${ }^{93}$ Ibid.

${ }^{94}$ Ibid. 
prominently opposed not only by environmental groups but also a wide variety of other groups, including domestic trade unions, international human rights groups (such as Amnesty International), development bodies (such as Community Aid Abroad), ${ }^{95}$ religious organisations, churches and nationalist political parties. One of the NGOs' main concerns against the treaty draft was its similarity to investor protection and dispute settlement provisions in Chapter 11 of NAFTA and the associated impact on the regulatory autonomy of host states. For example, NGOs were concerned that the protection against indirect expropriation would impede the normal regulatory measures of host states: ${ }^{96}$

Perhaps the greatest environmental threat the MAI poses is that the investor-state dispute procedure, any new laws to protect the environment, wilderness, species or natural resource protection could be considered a form of expropriation and foreign investors would have the right to sue for compensation before an international tribunal made up of unelected trade bureaucrats.

As a result, the exclusion of the NGOs from the MAI negotiations process was "the basis of the misperceptions and the mistrust that led them into a campaign to kill the MAI." ${ }^{97}$ Following the MAI episode, there is no doubt that future major international negotiations will require to be conducted within a public policy network. ${ }^{98}$ Discussions on international investment agreements require full and effective participation of all groups within civil society, in order to hear their views and benefit from their experiences. The process of international investment rule-making (including the negotiation of IIAs) could benefit from the input of NGOs. ${ }^{99}$

NGOs are particularly concerned with the perceived impact of trade and investment agreements on issues as diverse as the environment, labour standards and human rights. In this vein, NGOs have increasingly sought and attained limited rights to

\footnotetext{
${ }^{95}$ James Goodman "Stopping the Juggernaut: the Anti-MAI Campaign" in James Goodman and Patricia Ranald (eds) Stopping the Juggernaut: Public Interest Versus the Multilateral Agreement on Investment (Pluto Press, Annandale, 2000) 169.

${ }^{96}$ Maude Barlow and Tony Clarke MAI: The Multilateral Agreement on Investment and the threat to American Freedom (Stoddart, New York, 1998) 60.

${ }^{97}$ Katia Tieleman The failure of the Multilateral Agreement on Investment (MAI) and the Absence of a Global Public Policy Network (Case Study for the UN Vision Project on Global Public Policy Networks, European University Institute, Firenze and Harvard University, 2000) 6-7.

${ }^{98}$ Ibid.

${ }^{99}$ Ibid, 33-34.
} 
submit amicus curiae briefs ${ }^{100}$ within the dispute settlement process of the WTO, ${ }^{101}$ Chapter 11 of the North American Free Trade Agreement ${ }^{102}$ and ICSID. ${ }^{103}$

The NGOs' claim of a lack of transparency in NAFTA arbitrations led two NAFTA Tribunals to admit that they have the authority to accept amici curiae briefs. Such cases involve questions of great public importance like environmental issues. ${ }^{104}$

In the Methanex Case, ${ }^{105}$ the arbitral tribunal received a petition from several NGOs ${ }^{106}$ requesting that they be allowed: first, to file amicus briefs; second, to review the written pleadings of the parties; third, to make written and oral submissions, and fourth, to participate in the oral hearings. As a starting point, the arbitral tribunal noted that Article $15(1)$ of the UNCITRAL arbitration rules ${ }^{107}$ empowers a tribunal to conduct the proceedings between the parties in such manner as it deems appropriate, provided that the parties are treated on the basis of equality. The Tribunal concluded that by virtue of Article 15(1) of the UNCITRAL arbitration rules, it had the power to accept amicus curiae submissions in writing. ${ }^{108}$ However, the tribunal considered that it had no power to grant NGOs requests to receive materials generated within the arbitration or to attend oral

\footnotetext{
${ }^{100}$ For a detailed overview see Claudia Linden Too Many Friends for a Good Part? An Analysis of the Latest Developments in Third Party Participation in Investment Arbitration with Special Proliferation of Amicus Curiae Briefs (LLM Research Paper, Victoria University of Wellington, 2008).

${ }^{101}$ WTO European Communities - Measures Affecting Asbetos and Asbetos-Containing Products: Additional Procedure Adopted under Rule 16(1) of the Working Procedures for Appellate Review (Report of the Appellate Body, WTO Doc WT/DS/135/9, 8 November 2000) 50-57.

${ }^{102}$ NAFTA, above $\mathrm{n} 17$, the ability of a NAFTA arbitral tribunal to accept amicus curiae briefs was affirmed in NAFTA Chapter 11 Arbitration, United Parcel Service of America Inc v Government of Canada (17 October 2001) (Decision of the Tribunal on Petitions for Intervention and Participation as Amici Curiae). The other amicus curiae brief in NAFTA arbitration is: Methanex Corp v United States (15 January 2001) (Decision of the Tribunal on Petitions from Third Persons to Intervene as Amicus Curiae).

${ }^{103}$ Amicus curiae briefs in ICSID arbitration are: Biwater Gauff (Tanzania) Ltd. $v$ United Republic of Tanzania ICSID Case No. ARB/05/22; Suez, Sociedad General de Aguas de Barcelona SA v Vivendi Universal SA v Argentine Republic ICSID Case No. ARB/03/19 (19 May 2005) (Order in Response to a Petition for Transparency a Participation As Amicus Curiae); Aguas del Tunari SA Republic of Bolivia ICSID Case No. ARB/02/03 (21 October 2005) (Decision on Respondent's Objections to Jurisdiction).

${ }^{104}$ See Chapter III of the present dissertation, Section A, 3, 59 for the arguments raised in the amicus curiae submitted by the IISD in several cases and involving environmental concerns.

${ }^{105}$ Methanex Corp v United States, above n 69. All documents relevant to this case can be found on: http://www.state.gov/s/l/c5818.htm (last accessed 20 May 2009).

${ }^{106}$ In Methanex, the proposed amici were the International Institute for Sustainable Development, Communities for a Better Environment and the Earth Island Institute (the latter two petitioned jointly and were represented by the Earth Justice Legal Defence Fund).

${ }^{107}$ United Nations Commission on International Trade Law (UNCITRAL) Arbitration Rules (15 December 1976) UN Doc A/31/98.

${ }^{108}$ Methanex Corp v United States, above n 69, para 53.
} 
hearings of the arbitration. ${ }^{109}$ In UPS $v$ Canada, the arbitral tribunal relied on Methanex to a great extent. It also determined that it had the power to allow third party participation through the submission of amicus briefs. ${ }^{110}$

The role of NGOs and the policy of transparency in investment disputes are still being developed. The extent to which NGOs should be allowed to participate is the subject of an important public debate. ${ }^{111}$ It is beyond the scope of this dissertation to address that question in detail.

\section{B A Security Based on International Arbitration Tribunals}

The prescriptive reality is however more complex. This is mainly due to the original mechanism of disputes settlement which basically differentiates international investment law from other branches of international law. Bilateral investment treaties indeed generally open recourse to arbitration for a mixed dispute between the host state on the one hand and the foreign investor on the other. These tribunals are generally composed of three arbitrators, including two respectively selected by the parties to the convention and the third - the President - selected by mutual agreement of the two preindicated arbitrators. Such a composition is a pledge of neutrality for the arbitration tribunal. Thus, the foreign investor avoids the recourse to the domestic justice system which is one branch of the public authority of the opposing party and thus subjected to some doubt as to its impartiality in an investment dispute (even if one must assume the good faith of the national judge).

Moreover, international courts composed of private adjudicators are subject to very demanding effectiveness and discretion restrictions to which domestic justice cannot provide an equivalent in all countries. The tribunal of international arbitration is subjected to an extremely favourable procedural framework for the investor because its mandate is strictly limited to the investment dispute and it cannot therefore extend its jurisdiction to the cases pending against the investor, which can be the case under domestic law.

\footnotetext{
${ }^{109}$ Methanex Corp v United States, above n 69, para 47.

${ }^{110}$ United Parcel Service of America Inc v Government of Canada, above n 102, 24 para 61.

${ }^{111}$ Doak R Bishop, James Crawford and Michael W Reisman Foreign Investment Disputes: Cases, Materials, and Commentary (Kluwer Law International; The Hague, 2005) 16-17.
} 
Lastly, the arbitral tribunal obtains its mandate from international law and not under the national law of the host state, preventing the host state from changing the rules of the game according to suit themselves. This does not necessarily imply that the tribunal exclusively applies international law. On the contrary, the parties can agree on the application of the domestic law of the state-party or of any other national law. In principle the tribunal will, however, be held to control the choice of law selected by the parties in relation to the international legal order. In the respect of the law applicable to the substance of investment treaty arbitration, ${ }^{112}$ the principal provision setting out the choice of law is Article 42(1) ICSID Convention:

The Tribunal shall decide a dispute in accordance with such rules of law as may be agreed by the parties. In the absence of such agreement, the Tribunal shall apply the law of the Contracting State party to the dispute (including its rules on the conflict of laws) and such rules of international law as may be applicable.

Therefore according to the first sentence of this provision, the international investment treaty might provide its own choice of law rule. In the absence of an express agreement on applicable law, the tribunal will consider the respective roles of the law of the host state and of international law. The issue around the applicable law constitutes an important question in ICSID arbitration and has raised debate around its scope of meaning and interpretation. ${ }^{113}$

The iterative application of conventional texts by arbitration tribunals has inevitably resulted in a normative development of international investment law (and in particular of the principles or standards of protection of investments at the international level). Admittedly, this is a legitimate phenomenon in international law. Indeed, Article $38(1)(d)$. of the Statute of the International Court of Justice ${ }^{114}$ recognises that the interpretation of international law takes into account, inter alia, judicial decisions. The

\footnotetext{
${ }^{112}$ See Campbell McLachlan "Investment Treaty Arbitration: The Legal Framework" General report to International Council for Commercial Arbitration, Dublin Congress, Working Group A:II:A (ICCA, Dublin, 2008) 15-30; Antonio R Parra "Applicable Law in Investor-State Arbitration" in Michael Rovine (ed) Contemporary Issues in International Arbitration and Mediation: the Fordham Papers I (Martinus Nijhoff, Leiden, 2008) 1-15; Emmanuel Gaillard and Yas Banifatemi "The Meaning of "and" in Article 42(1), Second Sentence, of the Washington Convention: The Role of International Law in the ICSID Choice of Law Process" (2003) 18 ICSID Rev 375; Ole Spiermann "Applicable Law" in Peter Muchlinski, Federico Ortino and Christoph Schreuer (eds) The Oxford Handbook of International Investment Law (Oxford University Press, New York, 2008) 89-118. Christoph Schreuer The ICSID Convention: A Commentary (Cambridge University press, Cambridge 2001) 558.

${ }^{113} \mathrm{Ibid}$, see generally the literature mentioned above.

${ }^{114}$ Above $\mathrm{n} 35$.
} 
characteristic of international investment law lies however in the scope of the obligations drawn by the tribunals from the relatively vague conventional texts.

It is therefore necessary to provide a definition of essential terms in international investment law. These key-definitions are indicative and reflect a common practice in a number of bilateral treaties as interpreted by arbitral tribunals. States may, however, in certain cases, have chosen other definitions. ${ }^{115}$

Investment: ${ }^{116}$ a foreign corporation engages in several types of foreign investments. FDI is an investment by a firm in a foreign country to acquire real assets such as plant, equipment, and real estate or land with the aim of maintaining control over their management. FDI involves both ownership and control of the foreign entity by the corporation. A firm which controls operations or owns assets in more than one country is called a multinational corporation (MNC). MNCs are owned in their home countries and invest in host countries. Portfolio investment, in contrast, involves acquisition of foreign securities such as shares and bonds by firms without them acquiring any direct control over the management of the foreign entity. ${ }^{117}$

Fair and equitable treatment (FET): ${ }^{118}$ this treatment is analysed without reference to the treatment of other goods or people. It thus constitutes an absolute measure. Thus national treatment alone is insufficient because international law confers a level of protection which exceeds the one provided by the host state to its nationals. Thus a denial of justice ${ }^{119}$ would be, for example, incompatible with a fair and equitable treatment.

\footnotetext{
${ }^{115}$ For more details, see the glossary established by the UNCTAD Key Terms and Concepts in IIAs: A Glossary UNCTAD (United Nations Publications, New York and Geneva, 2004).

${ }^{116} \mathrm{M}$ Sornarajah The International Law on Foreign Investment (2ed, Cambridge University press, Cambridge, 2004) 7. See further, Rudolf Dolzer and Christoph Schreuer Principles of International Investment Law (1ed., Oxford University Press, New York, 2008) 60-71.

${ }^{117}$ The International Law on Foreign Investment, above n 116, 7-8.

${ }^{118}$ See Stephen Vasciannie "The Fair and Equitable Treatment Standard in International Investment Law and Practice" (1999) 70 BYIL 99. See also a more recent book providing a systematic analysis of the standard as it appears in investment treaties and as it is employed in international tribunals, Ioana Tudor The Fair and Equitable Treatment Standard in the International Law of Foreign Investment (Oxford University Press, Oxford, 2008).

${ }^{119}$ For a complete overview about denial of justice, see Jan Paulsson Denial of Justice in International Law (Cambridge University Press, Cambridge, 2005).
} 
Full protection and security of investment: ${ }^{120}$ the host state has the obligation to take any useful and necessary measure to protect the investment from destruction and despoliation even by third parties. An overall inaction of authorities of a host state in view of an imminent danger for the investment or the absence of judicial proceedings in case of breaches of the law and perpetrated against the investment would be incompatible with the obligation of full protection and security.

National treatment: ${ }^{121}$ this requires from host states to grant foreign investors and their investments treatment that is no less favourable than the treatment granted to domestic investors and investments.

Most-favoured-nation treatment $(M F N):{ }^{122}$ usually incorporated in IIAs as a general requirement. The standard requires that foreign investors and their investments enjoy treatment that is no less favourable than the treatment accorded to investors of any third states and their investment by the host countries.

Expropriation: ${ }^{123}$ it is the unilateral withdrawal by public authorities of the host state of the right of ownership of an investor or rights related to it (for example: possession, right of exploitation) unless it is a repressive reaction to the illicit behaviour of the investor. Therefore the taking of foreign investors' property is prohibited except if it is done for a public purpose, on a non-discriminatory basis, with payment of compensation, and, in many cases, with due process of law. According to the Hull Formula ${ }^{124}$ of 1936 named after the Secretary of State of the United States who applied this principle for the first time, international law requires "prompt, adequate and effective" compensation for the expropriation of foreign investments. First, compensation for expropriation must be prompt, meaning that it must be paid as soon as expropriation is carried out or within a reasonable time; secondly, it must be adequate as it should correspond to the monetary

\footnotetext{
${ }^{120}$ M Sornarajah The International Law on Foreign Investment, above n 116, 149.

${ }^{121}$ UNCTAD National Treatment (United Nations Publications, New York and Geneva, 1999) 18.

${ }^{122}$ UNCTAD Most-Favoured-Nation Treatment (United Nations Publications, New York and Geneva, 1999) 10.

${ }^{123}$ UNCTAD Taking of Property (United Nations Publications, New York and Geneva, 1999) 2.

${ }^{124}$ Above $\mathrm{n} 32$.
} 
value of the expropriated goods calculated during a period of time immediately preceding the advertisement of expropriation; and finally, it should be effective as the compensation must be put into payment in transferable and exchangeable form. Nowadays, the Hull formula is often used by a certain developed countries and accepted as part of customary international law.

\section{The New Content of International Investment Law}

Investors have enjoyed, for approximately twenty years, an increasing security of their assets located abroad. It is not that tribunals began making radically new interpretations, and awards against states remain very few in international arbitration.

$1 \quad$ Fair and equitable treatment standard to security against administrative vagueness

From the general obligation of fair and equitable treatment seen above, the tribunal in the Metalclad $v$ Mexico case could draw a true obligation of transparency of the administration of investments by the host state. ${ }^{125}$ It was considered to be incompatible with this obligation that the local district refused a building permit to the investor whereas the federal state had previously stated that the operation was possible. ${ }^{126}$

The tribunal in Tecmed extended this approach. Regarding the fair and equitable treatment, the tribunal held that the investor could legitimately expect that the framework and rules applicable to the investment would be identified, and that the behaviour of the state would remain coherent and stable relative to the framework thus established. ${ }^{127}$

2 Prohibition of the arbitrary to protection against the evolution of the law

\footnotetext{
${ }_{125}^{125}$ Metalclad Corp v United Mexican States ICSID (2000) (Award) 40 ILM 36 (NAFTA) para 74.

${ }^{126}$ Metalclad Corp v United Mexican States, above n 125, para 79.

${ }^{127}$ Tecnicas Medioambientales Tecmed SA v United Mexican States above n 55, para 154. See Christoph Schreuer "Fair and Equitable Treatment: Interactions with Other standards" (2007) 4 TDM 26, 17. Available http://www.swissinvestforum.ch/downloads/Presentations\%207\%20March\%202008/Schreuer\%20Christop h\%20II\%20-\%20Literature\%20II.pdf (last accessed 25 October 2008).
} 
Any change of the domestic legal system after the establishment of an investment could potentially breach international investment law. Indeed, it was determined in the Metalclad case that the transformation of a foreign investment site into a natural reserve, thus making the facilities of the investor unusable, amounted to a violation of fair and equitable treatment. ${ }^{128}$ This award even suggests a primacy of the protection of foreign investments over environmental concerns; at the same time, however, the investment treaty states that measures for the protection of the environment, taken in order to ensure environmental issues, are lawful. Article 1114 of NAFTA reads:

\footnotetext{
Nothing in this Chapter shall be construed to prevent a Party from adopting, maintaining, or enforcing any measure, otherwise consistent with this Chapter that it considers appropriate to ensure that investment activity in its territory is undertaken in a manner sensitive to environmental concerns.
}

Nevertheless, the tribunal found that the obligation of fair and equitable treatment had been violated by the host state Mexico in this particular case. ${ }^{129}$ The Tribunal interpreted the minimum standard of treatment to require, inter alia, "transparency" of all relevant legal requirements at all stages of the investment process. ${ }^{130}$ The Tribunal found that Mexican legislation contained no clear rule as to whether a municipal construction permit was required or not; furthermore, there was no established practice or procedure as to the manner of handling applications for a municipal construction permit. The Tribunal found a failure to ensure transparency on the part of Mexico. ${ }^{131}$ However, during the review of the decision of the Tribunal by the British Columbia Supreme Court, ${ }^{132}$ the Court found that there were no transparency requirements in NAFTA Chapter 11. According to the Court, applying transparency obligations to Chapter 11 disputes would be tantamount to creating new obligations, which would clearly be outside the

\footnotetext{
${ }^{128}$ Metalclad Corp v United Mexican States, above n 125, para 96.

${ }^{129}$ Ibid, para 98.

${ }^{130}$ Ibid, para 76.

131 Ibid, para 88 .

${ }^{132}$ Metalclad Corp v United Mexican States (2001) BCSC 664, 5 ICSID 236 (Supreme Court of British Columbia).
} 
jurisdiction of the Tribunal. ${ }^{133}$ Thus, the Court held that the Tribunal decided on a matter beyond the scope of the submission to arbitration. ${ }^{134}$

Moreover, a true security against the evolutions of the law has developed from the obligation to compensate indirect expropriations. This appears in the jurisprudence since the 1980s when the Iran-United States Claims Tribunal judged that the effect and not the subject-matter of an act were decisive in reference to the obligation to compensate for expropriation. ${ }^{135}$

From the obligation to compensate expropriations, even indirect ones, tribunals also find an obligation to compensate creeping expropriations. ${ }^{136}$ A creeping expropriation is characterised by a series of acts from public institutions having the cumulative consequence of the expropriation of the investment, even though none of the acts taken individually fulfil this condition. ${ }^{137}$ In the award in Generation Ukraine Inc $v$ Ukraine, creeping expropriation was defined as follows: $:^{138}$

\begin{abstract}
Creeping expropriation is a form of indirect expropriation with a distinctive temporal quality in the sense that it encapsulates the situation whereby a series of acts attributable to a State over a period of time culminate in the expropriatory taking of such property.
\end{abstract}

It has been decided that any concealed and iterative interference leading to the removal of a part or the entirety of the property rights from the investor, that are legitimately possessed, must be considered as tantamount to expropriation even though the interference does not occur to the benefit of the host state. ${ }^{139}$

Nevertheless, one might query the scope of this jurisprudence, knowing that economic operators frequently come up against combinations of fragmented regulations in their activities. Each regulation has, in itself, a raison d'être as part of the public

\footnotetext{
${ }^{133}$ Ibid, para 76.

${ }^{134}$ Ibid, para 74

${ }^{135}$ Starrett Housing Corp v Islamic Republic of Iran (Interlocutory Award) (1983) 4 Iran-USCTR 122 and Tippetts, Abbett, McCarthy, Stratton v TAMS-AFFA Consulting Engineers of Iran, the Government of the Islamic Republic of Iran (1984) 6 Iran-USCTR 219.

${ }^{136}$ See Burns H Weston “Constructive Takings' under International Law: A Modest Foray into the problem of Creeping Expropriation" (1975) 16 Va J Intl L 103.

${ }^{137}$ UNCTAD Taking of Property, above n , 18-19.

${ }^{138}$ Generation Ukraine Inc v Ukraine (2003) (Award) 44 ILM 404 (ICSID) paras 20-22.

${ }^{139}$ Metalclad Corp v United Mexican States, above n 125, para 103. Occidental Exploration and Production Co v Republic of Ecuador (2004) LCIA, Case No UN3467 (UNCITRAL) para 87. Available at: http://www.asil.org (accessed 28 July 2008).
} 
interest. One thinks in particular of the way the tax rules and regulations of different economic sectors can combine to cause prejudicial results for certain companies. The same applies to the field of consumer law. Regulatory effects of this kind can lead to indirect expropriation. Generally, expropriation refers to the use of any measures by the host country government which result in the transfer of property rights from the private owner to the government itself or a third party for any purpose. Normally, the term "expropriation" falls into two main categories: direct expropriation and indirect expropriation or any measure tantamount to expropriation. ${ }^{140} \mathrm{~A}$ direct taking of property may occur in many ways and forms, such as the nationalisation, confiscation, and dispossession of the assets of an investor, as long as it involves directly taking control of the rights belonging rightfully to the private owners. ${ }^{141}$ On the other hand, indirect expropriation, or any measures tantamount to expropriation, does not involve a seizure of control over the rights of the investor. Rather, it may involve a government measure that may "interfere" with the usage of the property rights instead of taking direct control of the assets. ${ }^{142}$ International arbitral tribunals have determined on several occasions, that indirect expropriation could cover a wide range of policy measures, such as the imposition of an arbitrarily disproportionate tax rate, the forced sale of equity, and the denial of access to legal materials.

The line between the concept of indirect expropriation and non-compensable regulatory governmental measures has not been systematically articulated. However, a close examination of the relevant jurisprudence reveals that, in broad terms, there are some criteria that tribunals have used to distinguish these concepts: the degree of interference with the property right, the character of governmental measures and the interference of the measure with reasonable and investment-backed expectations. ${ }^{143}$ The purpose and proportionality of the regulatory measures have also often been taken into account in order to determine whether compensation was due. Thus a number of cases have been determined on the basis of recognition that governments have the right to

\footnotetext{
${ }^{140}$ M Sornarajah The International Law on Foreign Investment, above n 116, 344.

141 Ibid, 345-346.

${ }^{142}$ August Reinisch "Expropriation" in Peter Muchlinski, Federico Ortino and Christoph Schreuer (eds) The Oxford Handbook of International Investment Law (Oxford University Press, New York, 2008) 421422.

${ }^{143}$ See ibid, 438-456.
} 
protect, through non-discriminatory actions, inter alia, the environment, human health and safety, market integrity and social policies without providing compensation for any incidental deprivation of foreign owned property. The quest for a generally-applicable distinction between the concept of indirect expropriation and a regulatory measure will be assessed in more detail in the analysis below. ${ }^{144}$

In any event, conventional practice has today acknowledged this evolution and the recent bilateral treaties of protection and promotion of investments include a clause about this phenomenon, which entitles the investor to compensation. ${ }^{145}$

A final step in the development of jurisprudence concerning indirect expropriations has been recently reached when several tribunals found, in particular cases, an obligation to compensate for the prejudicial effects of goods or administrative Acts of general scope, when they only secondarily harm the use of the property of a foreign investor ("regulatory expropriations"). ${ }^{146}$ The scope of this interpretation is potentially important. Contrary to the traditionalist view, ${ }^{147}$ tribunals refuse to consider the implementation in good faith of police powers of the state as an excuse for such an interference with the rights of foreign investors. ${ }^{148}$

Admittedly, the doctrine ${ }^{149}$ and certain awards ${ }^{150}$ consider that the states must continue to have freedom over domestic administration, especially in order to attain

\footnotetext{
${ }^{144}$ See further the discussion in Chapter III of the present dissertation, Section A, 5, 74.

${ }^{145}$ For example, see Accord entre le Gouvernement de la République Française et le Gouvernement de la République Populaire de Mongolie sur l'encouragement et la protection réciproques des investissements (France- République Populaire de Mongolie) (signed 8 November 1991, entered into force 22 December 1993) JO 24 March 1994 4469, Article 5 para 2; Treaty Concerning the Reciprocal Encouragement and Protection of Investment (US-Argentina) (signed 14 November 1991, entered into force 20 October 1994) Senate Treaty Doc 103-02, Article 4 para 1; Vertrag zwischen der Republic Kroatien und der Bundesrepublik Deutschland über die Förderung und den gegeinseitigen Schutz von Kapitalanlagen (Germany-Croatia) (signed 21 March 1997) Article 4 para 2.

${ }^{146}$ Metalclad Corp v United Mexican States, above n 125, para 103; Compaňia Del Desarrollo de Santa Elena, SA v Republic of Costa Rica (2000) (Award) 39 ILM 1317 (ICSID) para 77. For a more recent example of a restrictive view of expropriation SD Myers Inc v Government of Canada (2000) (First Partial Award) 40 ILM 1408 (NAFTA/UNCITRAL) para 282 and the comments made by Rudolf Dolzer "Indirect Expropriations: New Developments?" (2002) 11 N Y U Envtl L J 64, 85-86.

${ }^{147}$ Brewer, Moller and Co v Venezuela (Germany v Venezuela) Mixed Claims Commission (1903) X RIAA 423; Kügele v Polish State (1931-1932) Upper Silesian Arbitral Tribunal, Annual Digest 6, 69.

${ }^{148}$ Todd Weiler "NAFTA Arbitration and the Growth of International Economic Law" (2002) 36 Can Bus L J 405,158-162 in reference to the case Pope \& Talbot Inc v Government of Canada (2000) (Interim Award) 40 ILM 258 (NAFTA/UNCITRAL) para 96.

${ }^{149}$ American Law Institute Restatement of Law the Third, Foreign Relations Law of the United States (American Law Institute Publishers, St. Paul, Minn., 1987) para 712. See also George H Aldrich The
} 
objectives internationally recognised as of public interest (such as the environment and health) as well as to obtain necessary financing (through taxation) even where this results in unfavourable consequences for foreign investments. Every enterprise in the territory of its home state will be subject to such restrictions and it is difficult to argue that an investor should be better protected abroad than in his own country. ${ }^{151}$ One award has detailed the broad acceptance of regulatory expropriations in finding that the loss suffered by an investment caused by an environmental measure, like every measure of general interest, would lead to an obligation to compensate only if the measure were not proportional to a legitimate objective. ${ }^{152}$

The severity of the economic impact caused by a government action is now considered in most international decisions as an important element in determining whether it rises to the level of expropriation requiring compensation. ${ }^{153}$ Therefore, compensation was denied when the action of the host state did not remove essentially all or most of the economic value of the property of the foreign investor. On the contrary, a "substantial" interference in the fundamental rights of ownership will most likely constitute an expropriation entitled to compensation. ${ }^{154}$ Nevertheless, arbitral tribunals can today sanction host states even for the implementation of a simple tax regulation of general application since it would reflect a confiscatory nature, thus making the process of investment unprofitable. ${ }^{155}$

Nevertheless, a nuance was introduced in the Feldman Case. The claimant alleged that the application of certain tax measures from the Mexican government that denied an American cigarette producer certain tax rebates constituted a breach of article 1110 of NAFTA. The Tribunal declined to find an expropriation although it acknowledged that

\footnotetext{
jurisprudence of the Iran-United States Claims Tribunal (Clarendon press, Oxford, 1996) 209 which talks about an "accepted principle of international law" in this respect.

${ }^{150}$ For example, Emanuel Too $v$ Greater Modesto Insurance Associates and the United States of America (1989) 23 Iran-USCTR 378.

${ }^{151}$ The Oscar Chinn Case (United Kingdom v Belgium) (Judgement) [1934] PCIJ (Series A./B, No 63) 1. For a more recent perspective, see the grounds of the ICSID award in SD Myers Inc $v$ Government of Canada, above n 146, paras 281 and 282.

${ }^{152}$ Técnicas Medioambientales Tecmed SA v United Mexican States, above n 55, para 122.

${ }^{153}$ Naewmalee Kiratipong "Protecting Foreign Investments against Expropriation Measures: Risks and Concerns Related to the New Draft Amendment of the Foreign Business Act of 1999” (2007) 22 TDRIQR 20, 22.

${ }^{154}$ Ibid, 22

${ }^{155}$ Feldman v United Mexican States (2002) (Award) 42 ILM 625 (NAFTA/ICSID (AF)) paras 103-106.
} 
the investor effectively lost the ability to export cigarettes and any profits derived as a result of the tax regulation. The Tribunal found that since exports played only a minor role in the overall business undertakings of the American company, the particular government tax measure did not substantially affect the interests of the private investor. ${ }^{156}$ Hence, general taxation is not always expropriatory.

Moreover, certain recent investment treaties now include clauses prohibiting excessive taxation of their nationals in the territory of the other state party. ${ }^{157}$ This raises the issue of the distinction between appropriate and excessive taxation on which arbitral tribunals will have to decide.

\section{An international contract law to an international legal security of contracts}

Although the terminology might suggest that the concept of expropriation is limited to the unilateral withdrawal of a good of which the prejudiced party was owner, tribunals also recognise an obligation to compensate expropriation for debts, hitherto seen as simple contractual rights. ${ }^{158}$ Yet, arbitration case law discovered the existence of "owners of a contractual right" while sanctioning, as an expropriation, a domestic measure of public interest which would make impossible the execution of the contract concluded with a private party. ${ }^{159}$

In this context, a new category of jurisprudence is interested in state contracts which are directly concluded between the private investor and host state as private parties. It implies that the arbitrary or confiscatory non-performance by the state party can lead to an obligation to compensate the investor under international law. Indeed an award of an ICSID tribunal was annulled for the reason that it failed to analyse a violation of a state contract under international law while at the same time the contract

\footnotetext{
${ }^{156}$ Ibid, para 111.

${ }^{157}$ For example, see Treaty Concerning the Encouragement and Reciprocal Protection of Investment (United States of America-Republic of Ecuador) (signed 27 August 1993, entered into force 11 May 1997) Senate Treaty Doc 103-15, Article X (c).

${ }^{158}$ Norwegian Shipowners' Claims Norway v United States of America (13 October 1922) PCA, I RIAA 307.

${ }^{159}$ Técnicas Medioambientales Tecmed SA v United Mexican States, above n 55, para 151.
} 
expressly indicated that questions of interpretation of the contract should be decided by a domestic judge. ${ }^{160}$

This jurisprudence is surprising not because the state is bound to compensate (the state would be also bound by virtue of the domestic contractual law of that state in case of violation) but because the investor can appeal to international arbitration tribunals to this effect with international law in support. Therefore, the foreign investor appears to be better protected than if he had contracted with a private party or with its home country. Admittedly, arbitration tribunals have indicated that the violation of a contractual clause by the host state does not automatically constitute a violation of international law, and in particular of the bilateral investment treaty. ${ }^{161}$ Nevertheless, a contractual breach of domestic law can be called upon today by the investor with the support of a claim for compensation, for example, for arbitrary treatment. ${ }^{162}$ Today, it is easier to maintain that an act can be impugned at both domestic and international law. Thus, a certain measure taken by the host state may constitute a breach of contract as well as a violation of international law. ${ }^{163}$ Nevertheless, the two categories of violations require the application of two different standards to determine whether one, or the other, or both have been breached. ${ }^{164}$ Therefore, "A state may breach a treaty without breaching a contract, and vice versa..."165 "... whether there has been a breach of the BIT and whether there has been a breach of contract are different questions." ${ }^{166}$ Christoph Schreuer explains that contract claims may fall under the competence of an arbitration tribunal if one of the following three conditions is met: ${ }^{167}$

\footnotetext{
${ }^{160}$ Compaňia de Aguas del Aconquija SA and Vivendi Universal v Argentine Republic (2002) (Decision on Annulment) 41 ILM 1135 (ICSID) para 102.

${ }^{161}$ Ibid, para 95. Consortium RFCC v Kingdom of Morocco (2003) (Award) 20 ICSID Rev-FILJ 391 (ICSID) para 41.

${ }^{162}$ See Elettronica Sicula S.p.A. (ELSI) (United States v Italy) (Jurisdiction and Admissibility) [1989] ICJ Rep 15, para 124.

${ }^{163}$ South Pacific Properties (Middle East) Ltd (SPP) v Arab Republic of Egypt (1992) (Award) 32 ILM 986 (ICSID) paras 164-167.

${ }^{164}$ Azinian, Davitian \& Baca v United States of Mexico (1999) (Award) 39 ILM 537 (NAFTA); Waste Management Inc $v$ United Mexican States ('Waste Management II') (2004) (Award) 43 ILM 967 (NAFTA/ICSID (AF)) paras 163 et seq.

${ }^{165}$ Compaňia de Aguas del Aconquija SA and Vivendi Universal v Argentine Republic, above n 160, para 95.

${ }^{166}$ Ibid, para 96.

${ }^{167}$ Christoph Schreuer "The Relevance of Public International Law in Commercial Arbitration: Investment Disputes" (2005) 8 .
} 


\begin{abstract}
- The claimant asserts that the breach of the contract amounts to a violation of one or several of the BIT's substantive standards (for example fair and equitable treatment, full protection and security, restrictions on the right to expropriate)

- The arbitration clause in the BIT is not restricted to violations of the BIT's substantive provisions but covers disputes with respect to investments in general,

- The BIT contains an "umbrella clause" converting a breach of contract into a violation of the BIT.
\end{abstract}

"Umbrella clauses," which stipulate in very general terms that the state must respect its commitments towards the investor, have the potential to raise to the level of international law any contractual violation, ${ }^{168}$ since the interpretation of this clause shows that the parties at the convention indeed wished the clause to catch purely contractual disagreements. ${ }^{169}$

Thus, the prescriptive context has evolved in a direction favourable to the foreign investor, and this even if all the examples of interpretation quoted above are not necessarily shared by all judges called to rule in comparable cases. However, there is an important probability that in future, tribunals may rule in one single direction while being based on many solid precedents. Still, it is necessary in order to estimate the impact of the evolutions, to question whether international investment law has some practical significance.

${ }^{168}$ SGS Société Générale de Surveillance SA v Republic of the Philippines, above n 66, para 135.

${ }^{169}$ SGS Société Générale de Surveillance SA v Islamic Republic of Pakistan (2003) (Jurisdiction) 42 ILM 1290 (ICSID) para 171 


\section{CHAPTER III STUDY OF THE IMPACT OF CONTRADICTORY IMPERATIVES IN PUBLIC LAW OF HOST STATES IN RELATION TO THE SECURITY EXPECTATIONS OF FOREIGN INVESTORS}

The evolution, nature and context of international investment law have been outlined. ${ }^{170}$ It has been established that host states are confronted with new legal constraints with respect to foreign investors, constraints which they cannot elude in practice. However this is not the only reason that host states are faced with a dilemma today. Host countries cannot conform to the requirements of international law without facing difficulties.

Nevertheless, the requirements of international investment law can have significant impacts on the implementation of public policies within a host state. In most cases, the economic role of the state has shifted from a direct public ownership of private operators to a regulatory authority by means of taxing, environmental, labour and social instruments. ${ }^{171}$ The regulatory function of the state and how it impacts on foreign investment has become a central issue with regard to the development of international law and policy. ${ }^{172}$ An increasing body of investor-state disputes where the issue of balancing investors' rights with host countries' policy space and regulatory flexibility has been challenged under trade and investment treaties illustrates this important evolution. ${ }^{173}$ A study from the WTO and the World Bank has determined the necessity of an appropriate and effective domestic regulatory environment in order to ensure the achievement of medium and long-term benefits of trade and investment liberalisation. ${ }^{174}$ The policy space of host countries is often described as the space where states have a

\footnotetext{
${ }^{170}$ See Chapter II of the present dissertation: A Brief Historical Review of the Evolution of International Investment Law: Slowly Increasing and Effective Security for Foreign Investors.

${ }^{171}$ Abba Kolo, Thomas W Wälde "Coverage of Taxation Under Modern Investment Treaties" in Peter Muchlinski, Federico Ortino and Christoph Schreuer (eds) The Oxford Handbook of International Investment Law (Oxford University Press, New York, 2008) 306.

${ }^{172}$ Howard Mann The Right of States to Regulate and International Investment Law Comment in Expert Meeting on the Development Dimension of FDI: Policies to Enhance the Role of FDI in Support of the Competitiveness of the Enterprise Sector and the Economic Performance of Host Economies, Taking into Account the Trade/Investment Interface, in the National and International Context (IISD, Geneva, 6-8 November 2002) 2.

${ }^{173}$ Ibid.

${ }^{174} \mathrm{H}$ Nordström and S Vaughan Trade and Environment (WTO, Geneva, 1999) 4; See P Frederiksson Trade, Global Policy, and the Environment (World Bank, Washington DC, 1999).
} 
sovereign right to regulate within their territory, while at the same time the state must abide by rules of both international and national law. ${ }^{175}$ The lawfulness of a host state's regulations and policies is more frequently being challenged by investors. ${ }^{176}$ Investor protections contained in investment agreements have the capacity to limit to a large extent the policy space of host governments and their abilities to regulate in the public interest. $^{177}$

Accordingly, the invocation by investors of provisions regarding public policies and contained in some investment treaties has developed an international jurisprudence about regulatory-related investment disputes. In the light of such international jurisprudence, the disputes arising out of such conflicted interests will be discussed. Then, it will be specified at what point either the security of investments, or the concerned regulatory public policies, are likely to adapt. A newly-worded treaty appears to be necessary in order to respond to the conflicts previously identified. This step will finally make it possible to highlight the heart of the problem.

\section{A Public Policies Jeopardised by the International Security of Investments}

It is generally agreed as a principle of international law that, as sovereign entities, states are entitled to regulate their national economies independently within their territory. ${ }^{178}$ Undeniably, the sovereign right to regulate is one of the main components of the traditional conception of statehood in international law that effects the activities of foreign investors. ${ }^{179}$ Investors are subjected to many public policies in force in the host state such as the relevant taxation laws as well as regulations related to competition, company laws and employment and environmental protection amongst others. ${ }^{180}$ The majority of public policies have the potential to impact foreign investors. Such impact is likely to constitute a breach of international obligations where a broad definition of fair

\footnotetext{
${ }^{175}$ Fiona Marshal and Vicente Yu Investors' Obligations and Host State Policy Space $2^{\text {nd }}$ Annual Forum of Developing Country Investment Negotiators (IISD, Marrakech - Maroc, 3-4 November 2008) 14.

${ }^{176}$ Ibid, 14 .

${ }^{177}$ Ibid, 14 .

${ }^{178}$ Fiona Beveridge The Treatment and Taxation of Foreign Investment Under International Law: Towards International Disciplines ( $1^{\text {st }}$ ed, Manchester University Press, Manchester, 2000) 5.

${ }^{179}$ Methanex Corporation v United States of America, above n 102, 2.

${ }^{180}$ Fiona Beveridge, above n 178, 5.
} 
and equitable treatment is adopted, or where the expropriation of an overseas investment is established, even if it is indirect, creeping ${ }^{181}$ or lawful.

In the context of this section, the level of respect that arbitration tribunals have paid to host states' policy space will be assessed through five selected domestic public policies. This will illustrate the potential conflict between the investment security obligations of a host country and its domestic regulatory measures. For each public policy, the following analysis will be considered: first of all, the scope of coverage of each policy in IIAs will be identified. Then the applicability of core substantive investment security provisions to regulatory measures will be highlighted in case law before being critically analysed.

\section{$1 \quad$ Tax law}

Taxation is, undoubtedly, one of the first elements that potential foreign investor will look at. It is often one of the aspects which can make the host state more competitive than the home country of an investor, and thus conducive to relocation. Hence international investment law shows a strong interest in taxation, for several reasons detailed below.

Host states are sovereign with regard to the sectors of the economy in which they allow foreign investors to operate. ${ }^{182}$ Tax policy is a matter that clearly falls within the customary regulatory powers of the state. Thus, governments can specify to what extent financial limits (minimum or maximum) may apply on investments and what kind of restrictions, if any, are placed on the import or export of goods or services, allocations of profits, and taxes and other levies to be paid. ${ }^{183}$ Nevertheless, host states are also subjected to certain obligations towards home states to respect the rights of foreign investors established within their territory. ${ }^{184}$

(a) Scope of coverage of taxation provisions in investment agreements

\footnotetext{
${ }^{181}$ Generation Ukraine Inc v Ukraine above n 138. Also see Burns H Weston "Constructive Takings' under International Law: A Modest Foray into the problem of Creeping Expropriation" (1975) 16 Va J Intl L 103.

${ }^{182}$ Fiona Beveridge, above n 178, 5.

183 Ibid, 5-6.

${ }^{184}$ Ibid, 6.
} 
Many different ways of treating taxation in modern bilateral and multilateral investment treaties deserve to be closely analysed. The types of taxes covered and the issues surrounding such coverage are discussed below.

International investment agreements make provision for taxation issues only to a limited extent on the admission, treatment and protection of foreign investment. Such provisions are not many in number because large networks of tax treaties - such as double taxation treaties - exist in parallel. UNCTAD defines such treaties as: ${ }^{185}$

\begin{abstract}
mostly of a bilateral nature and aim at the avoidance of double taxation .... Such treaties, which are often based on model conventions developed by the OECD and the United Nations, provide for the allocation of exclusive or shared taxing rights to the contracting parties and for commonly agreed definitions.
\end{abstract}

In 2004, the UNCTAD issued a glossary in which it provided examples of relevant provisions in IIAs concerning taxation measures. ${ }^{186}$ Provisions from BITs, NAFTA and the Energy Charter Treaty (ECT) will be examined. ${ }^{187}$ It appears that if some BITs state that the provisions on national and MFN treatment do not apply to tax matters, ${ }^{188}$ others do extend those standards of treatment to legislation relating to taxation. An example of a formulation of the exemption of taxation issues appears in Article 4 of the BIT between the Netherlands and Paraguay. ${ }^{189}$ As a result, national and MFN treatment are granted to investors of the other party by each of the parties in respect of taxes, fees, charges and fiscal deductions and exemptions, except for fiscal advantages accorded by a party "(1) under an agreement for the avoidance of double taxation; (2) by virtue of its participation in a customs union, economic union or similar institution, or (3) on the basis of reciprocity."

\footnotetext{
${ }^{185}$ UNCTAD Key Terms and Concepts in IIAs: A Glossary, above n 115, 146.

186 Ibid.

${ }^{187}$ See further, UNCTAD World Investment Report 1993: Transnational Corporations as Integrated International Production (United Nations Publications, New York and Geneva, 1993) Chapter X; Peter T Muchlinski Multinational Enterprises and the Law (Oxford: Blackwell, 1999) 277-321.

${ }^{188}$ Belgo-Luxemburg Economic Union Model BIT, Article 4(4); Agreement on the Mutual Promotion and Protection of Investments (Republic of Korea - Mongolian People's Republic) (1991) Article 7 (b).

${ }^{189}$ Agreement on Encouragement and Reciprocal Protection of Investments (Kingdom of the NetherlandsRepublic of $\quad$ Paraguay) $29 \quad$ October 1992). Available at http://www.unctad.org/sections/dite/iia/docs/bits/netherlands_paraguay.pdf (accessed 22 September 2008).
} 
The coverage of taxation matters in investment agreements may also be limited by a general stipulation stressing that only expropriation protection will apply to taxation. ${ }^{190}$ Thus, for example, some United States BITs have a clause stating that no provisions of the treaty shall impose obligations to taxation, except if a taxation measure amounts to an expropriation, then the expropriation and arbitration provisions will apply to claims resulting from it. ${ }^{191}$ This kind of exclusion reflects a strong protection of investors under the investment treaty at the expense of the discretion of host states in their use of tax measures as an instrument of regulatory power. ${ }^{192}$ Such an approach relies on the definition of expropriation provided in the IIA as well as on whether a clear distinction between legitimate taxation measures and measures whose effect is to effectively expropriate the investment is expressly stipulated in the agreement. ${ }^{193}$ Also, the investorstate arbitration procedures will apply to taxation issues arising in the context of investment agreements or investment authorisations. ${ }^{194}$

By contrast, other BITs contain a general exception on taxation. The BIT between Argentina and New Zealand is illustrative of one type of general exception that excludes all taxation matters from the scope of application of the agreement. Article 5 reads: ${ }^{195}$

The provisions of this Agreement shall not apply to matters of taxation in the territory of either Contracting Party. Such matters shall be governed by the domestic laws of each Contracting Party and the terms of any agreement relating to taxation concluded between the Contracting Parties.

Thus, regardless of the degree of inconsistency with any of the treaty obligations, no taxation laws or regulations could be successfully challenged under the BIT. Several

\footnotetext{
${ }^{190}$ UNCTAD Key Terms and Concepts in IIAs: A Glossary, above n 115, 144.

${ }^{191}$ For example, Treaty between the Government of the United States of America and the Government of the Republic of Bolivia concerning the Encouragement and Reciprocal Protection of Investment (18 April 1998) Article XIII.

${ }^{192}$ UNCTAD International Investment Agreements: Key Issues Volume II (United Nations, New York and Geneva, 2004) 232.

193 Ibid.

${ }^{194}$ See, for example, Treaty Concerning the Encouragement and Reciprocal Protection of Investment (United States of America-Republic of El Salvador) (10 March 1999) Article XIII (1); Treaty Concerning the Encouragement and Reciprocal Protection of Investment (United States of America-Bolivia) (signed 17 April 1998, entered into force 6 June 2001) Senate Treaty Doc 106-25, Article XIII (1) and Treaty Concerning the Encouragement and Reciprocal Protection of Investment (United States of AmericaRepublic of Nicaragua) (1 July 1995) Senate Treaty Doc 106-33, Article XIII (1).

195 Agreement for the Promotion and Reciprocal Protection of Investments (Argentine Republic-New Zealand) (27 August 1999) Article 5 (2).
} 
reasons for a general exception on taxation are to be identified. Dealing with exclusively international taxation issues in separate treaties is considered by many countries as the best way to retain maximum fiscal sovereignty. ${ }^{196}$ It is noticed that the density and complexity of tax issues might constitute matters incompatible with provisions of standards of treatment generally found in BITs. ${ }^{197}$

Another interesting example is the reference to taxation measures in the 2004 Canadian model BIT. ${ }^{198}$ This clause attempts to strike a balance between the protections that the BIT and an investment contract may provide to an investor, on the one hand, and the concern of the government authorities to safeguard flexibility to implement their fiscal policies, on the other. Thus, the BIT does not, in principle, apply to taxation measures, unless the competent authorities of each contacting party disagree among themselves that they in fact amount to an expropriation or that such measures violate a contract previously agreed between the investor and the host country.

Article 2103 of NAFTA reserves special treatment to taxation and follows a rather complex structure in relation to tax matters. NAFTA contains a general exclusion of taxation issues, ${ }^{199}$ but then outlines a general rule of non-application to specific subjects. Firstly, national and MFN treatment apply to taxation measures other than certain categories, including taxes on income, capital gains or on the taxable capital of corporations and taxes on estates, subject to exceptions for advantages granted pursuant to double taxation treaties and to country-specific reservations. ${ }^{200}$ Secondly, the provisions of NAFTA that prohibit the imposition of performance requirements as a condition for the receipt of an advantage also apply to taxation measures. ${ }^{201}$ Thirdly, an investor may refer the issue of whether or not a measure is an expropriation to international arbitration only if the competent tax authorities have failed to agree on it within a period of six months after the date on which the matter is referred to them. ${ }^{202}$

\footnotetext{
${ }^{196}$ UNCTAD International Investment Agreements: Key Issues Volume II, above n 192, 216.

${ }^{197}$ Ibid.

${ }^{198}$ Canadian Model Foreign Investment Protection Agreement (FIPA or Canada Model BIT) Agreement between Canada and __ for the Promotion and Protection of Investments (2004). Available at: http://ita.law.uvic.ca/documents/Canadian2004-FIPA-model-en.pdf (accessed 18 October 2008).

${ }^{199}$ North American Free Trade Agreement (NAFTA), above n 17, Chapter XI, Articles 2103(1) and (2).

${ }^{200}$ Ibid, Article 2103(4).

${ }^{201}$ Ibid, Article 2103(5).

${ }^{202}$ Ibid, Article 2103(6).
} 
Finally, the $\mathrm{ECT}^{203}$ follows a similar approach to that taken under NAFTA. The ECT contains provisions on the application of its investment disciplines to taxation issues after the general exclusion of taxation matters provided in Article 21(1). By virtue of Article 21(3), the national and MFN treatment provisions apply to taxation measures other than those on income or on capital, but they shall not impose MFN obligations with respect to (1) advantages accorded by a party pursuant to double taxation treaties, and (2) they do not apply to measures aimed at ensuring the effective collection of taxes. With regard to expropriation, Article 21(5) requires that questions whether a taxation measure has expropriatory effects, or whether a taxation measure alleged to constitute an expropriation is discriminatory, be submitted in the first instance to the competent tax authorities of the contracting parties concerned.

The fiscal concerns or taxation of the host country, regardless of the tax rate applied to the concerned investor, might be excessively complex, opaque, or even contain contradictory rules. Its pure and simple application by the host state can be considered incompatible with international investment law in the field of fair and equitable treatment. However, that does not exempt the investor from the obligation to get information, if necessary by using lawyers, about the tax law applicable in the host state. Complexity in itself is, as a result, not constitutive of a violation of the rights of the foreign investors. Besides, taxation does not amount to a taking. Nevertheless, when a state enforces a tax qualified as unreasonable or discriminatory, an expropriation will be found. ${ }^{204}$ A need to define expropriation with respect to tax measures becomes necessary. Such a need also applies to other fundamental substantive provisions of IIAs.

This section has examined a wide range of models of tax provisions in IIAs. Various tax provisions aim to reflect either an exclusion of such issues from a treaty or the inclusion of very specific tax issues. The question remains to what extent and under what conditions the imposition of certain taxes could constitute a violation of the standards of protection contained in IIAs.

(b) Tax-related arbitral awards

\footnotetext{
${ }^{203}$ Energy Charter Treaty (ECT) above n 18.

${ }^{204}$ UNCTAD International Investment Agreements: Key Issues Volume II, above n 192, 230.
} 
The general scope of coverage of tax under investment treaties having been outlined, it is now time to examine how arbitral jurisprudence has treated tax-related investment disputes. The growing number of recent tax-related arbitral awards and the increasing reliance by foreign investors on investment treaties for protection clearly points to the rising importance of tax disputes between foreign investors and host states. ${ }^{205}$ In the context of the present study, only a few cases will be examined. First, cases where the investor alleges that he has been subjected to discrimination or denied fair and equitable treatment by the host state will be considered. Then the study will assess cases where the investor has claimed that the host states measures have effectively caused an expropriation of his/her investment.

The application of the FET standard is generally excluded for tax matters under an investment treaty. ${ }^{206}$ For example, NAFTA Article 2103(1) states in part: "Except as set out in this Article nothing in this agreement shall apply to taxation measures." Likewise, the ECT in Article 21(1) reads: "Except as otherwise provided in this Article, nothing in this Treaty shall create rights or impose obligations with respect to taxation measures of the contracting parties." Nonetheless, some investment treaties expressly provide for the application of the FET to tax matters, while others exclude it together with other substantive investment protection provisions.

The case Occidental Exploration \& Production Co v Republic of Ecuador ${ }^{207}$ is illustrative of a non-NAFTA investment-treaty arbitration award raising tax issues conflict. Indeed, the case arose out of a dispute between a United States-based Occidental Petroleum investor (OEPC) and the government of Ecuador over refunds of ValueAdded-Tax (VAT) paid by Occidental to Ecuadorian tax authorities. In 1999, OEPC and

\footnotetext{
205 The main tax-related cases founded on BITs are : Marvin Feldman v Mexico, above n 155; Occidental Exploration \& Production Co $v$ Republic of Ecuador, above n 139; Goetz and Others $v$ Republic of Burundi ICSID case No. ARB/95/3 (1999) 5 ICSID Report 1; Link-Trading Joint Stock Co v Moldova, Final Award (18 February 2002); EnCana Corporation v Republic of Ecuador, LCIA Case o UN3481 (February 2006); Corn Products International Inc v Mexican States (2008) (Decision on Responsibility) ICSID Case No. ARB(AF)/04/01 and Archer Daniels Midland Co. \& Tate Lyle Ingredients Americas, Inc $v$ United Mexican States (2004) respectively; Grand Rivers Enterprises Six Nations, Ltd et al, v USA ; Enron Corporation \& Ponderosa Assets LP $v$ The Argentine Republic (2007) (Award) ICSID Case No. ARB/01/3 (ICSID) all available at http://www.investmentclaims.com or at http://www.ita.law.uvic.ca (last accessed 10 June 2009).

${ }^{206}$ Abba Kolo, Thomas W Wälde "Coverage of Taxation Under Modern Investment Treaties", above n 171,328

207 Occidental Exploration \& Production Co. v Republic of Ecuador, above n 139.
} 
Petroecuador (a state-owned corporation) entered into a modified participation contract for undertaking exploration and production of oil. During the course of its activities, OEPC had to pay VAT on goods and services but was entitled to claim a refund of these taxes. However, in 2001, the local tax authorities denied the refund requests and also demanded that the firm return the amounts of VAT which had been already reimbursed to them by the government. The regulatory measure taken by the government was founded on a VAT reform from the Ecuadorian tax authorities. In its award, the tribunal found that Ecuador had breached the United States-Ecuador BIT ${ }^{208}$ in several ways including in particular a breach of the national treatment obligation as well as the FET. First, the tribunal found that OEPC received a less favorable treatment in comparison to other local economic actors who were still entitled to VAT refunds under Ecuadorian tax law. ${ }^{209}$ Second, the tribunal held that Ecuador failed in providing Occidental with a FET $^{210}$ in light of Article $\mathrm{X}(1)$ of the US-Ecuador BIT which reads: "With respect to its tax policies, each Party should strive to accord fairness and equity in the treatment of investment of nationals and companies of the other party". Also, through references to the preamble of the $\mathrm{BIT}^{211}$ (The preamble provides that "fair and equitable treatment of investment is desirable in order to maintain a stable framework for investment and maximum effective utilisation of economic resources") and other awards as guidance, ${ }^{212}$ the tribunal determined that the United States firm faced a vague and unstable legal and business environment and that such a lack of clarity in tax law changes about its meaning, extent, practice and regulations amounted to a denial of fair and equitable treatment. ${ }^{213}$

The arbitral tribunal considered that the standard of treatment required by Article $\mathrm{X}(1)$ of the United States-Ecuador BIT is not devoid of legal significance: ${ }^{214}$

\footnotetext{
${ }^{208}$ Treaty Concerning the Encouragement and Reciprocal Protection of Investment (United States of America-Republic of Ecuador) above $\mathrm{n} 157$.

${ }^{209}$ Occidental Exploration \& Production Co. v Republic of Ecuador, above n 139, para 177. US-Ecuador BIT, above n 157, Article II(1).

${ }^{210}$ Ibid, para 180.

${ }^{211}$ US-Ecuador BIT, above n 157, Preamble; Award, para 183. The preamble provides that "fair and equitable treatment of investment is desirable in order to maintain a stable framework for investment and maximum effective utilisation of economic resources."

${ }^{212}$ Ibid, paras 183 and 184.

${ }^{213}$ Ibid. paras 183 and 185.

${ }^{214}$ Ibid, para 70.
} 
It imposes an obligation on the host state that is not different from the substantive obligation of fair and equitable treatment... even though this article involves a commitment that cannot be ignored by the parties in the implementation of their tax policies.

This explanation was supported by the Explanatory Note to the Treaty from the United States government which stated that the article X(1) of the BIT on tax policies "exhorts both countries to provide fair and equitable treatment to investors with respect to tax policies." 215

The host state may be sanctioned for discriminatory taxation. The two main principles of national treatment and most-favoured nation necessitate each party to provide treatment that is no less encouraging than that presented to its domestic investors, or that of any third party state, which face the same situations. ${ }^{216}$ Nevertheless, in addition to the standards of treatment, with regards to tax matters, there are exceptions which do not require contracting parties to extend to other contracting parties the advantages or privileges concerning whole or partial taxation given to investors of a third state. ${ }^{217}$ The fundamental objective of such provisions is to strike a balance between the core of the obligations of non-discrimination and economic sovereignty of states to confer new treaties and ratify new legislation which would suit the needs of the third party better without jeopardising the NT and MFN obligations. ${ }^{218}$ This facilitates states bound by an investment treaty to make the best of the changing fiscal and political climate, by way of negotiating tax benefits for the third state without contravening their treaty requirements. ${ }^{219}$ There are often exceptions involved in the current treatment practices involved in BITs, primarily to circumvent the export of individual tax arrangements per double taxation treaty, by regional fiscal amalgamation, legislation, and finally by special project contracts. ${ }^{220}$ Perhaps the most important application of both standards is in scenarios where a government either deliberately or inadvertently

215 See US government Explanatory Note attached to the US-Ecuador BIT, 8. Available at: http://www.state.gov/documents/organization/43558.pdf (last accessed 11 July 2009).

${ }^{216}$ Abba Kolo, Thomas W Wälde "Coverage of Taxation Under Modern Investment Treaties", above n $171,325$.

${ }^{217}$ Ibid, 325

${ }^{218}$ Ibid, 326.

${ }^{219}$ Ibid, 326.

${ }^{220}$ Ibid, 328. 
discriminates between domestic investors on the one hand and foreign investors in competition with domestic investors, on the other. ${ }^{221}$

Even in the event of very favorable taxation initially - where the rate applied to the investor is low or exemptions or refunds are available - the host country will be required to compensate an investor deprived of effective use of his goods and assets. By contrast, the taxation of the host state can also be detrimental to the existence of the investment. Therefore, international law will be able to punish this system in accordance with the prohibition of excessive taxation that appears in some recent bilateral conventions of protection and promotion of investments. An indirect expropriation may arise if the property of a foreign investor is subjected to excessive and repetitive taxation without sufficient justification for such a heavy taxation. ${ }^{222}$ If a contracting party adopted taxation measures inconsistent with any of the obligations of the agreement other than those on national treatment and MFN treatment, they could in principle, be challenged under the dispute settlement procedures contained in the BIT (for example: an excessive taxation amounting to indirect expropriation after "confiscatory tax measures"). Situations in which a taking may not occur can be found among the taxation of windfall profits $^{223}$ (unexpected profits arising from causes not controlled by the investor). ${ }^{224}$ Moreover, Sornarajah points out that "taxation of the oil industry for windfall profits due to price hikes cannot amount to a taking." In contrast, international authorities remark that taxation can amount to an expropriation. ${ }^{225}$

In this light, the case Link-Trading $v$ Moldova $^{226}$ dealt with a claim that changes in customs and tax regulations were expropriatory. In its claim under the 1993 United States-Republic of Moldova BIT, the claimant alleged it suffered an indirect expropriation because of a change in the rates of duties and VAT exemptions, which

\footnotetext{
${ }^{221}$ Ibid, 328.

${ }^{222}$ World Bank Report and Guidelines (1992) 31 ILM 1375.

${ }^{223}$ American Independent Oil Company (Aminoil) v State of Kuwait, above n 42.

${ }^{224}$ M Sornarajah The International Law on Foreign Investment, above n 116, 393.

${ }^{225}$ See generally Abba Kolo and Thomas Wälde "Confiscatory Taxation under Customary International law and Modern Investment Treaties" (1999) 4 CEPMLP I J 17, available at http://www.dundee.ac.uk/cepmlp/journal/; William W Park "Expropriation and Taxation in the NAFTA" in Weiler, Todd (ed) Investment Law and Arbitration: Past Issues, Current Practice, Future Prospects (Transnational Publishers, New York, 2004) 93; William W Park “Arbitration and the Fisc: NAFTA's Tax Veto" (2001) 2 Chi J Intl L 231, 2:1.

${ }^{226}$ Link-Trading Joint Stock Company v Department for Customs Control of Republic of Moldova above $\mathrm{n}$ 105.
} 
caused the failure of the claimant's business consisting essentially of the import of consumer products into the Free Economic Zone of Chisinau and their resale to Moldovan customers. ${ }^{227}$ The tribunal held that fiscal measures become expropriatory when they amount to an "abusive taking". ${ }^{228}$ The terms of unfairness, arbitrariness and discrimination or the violation of a state undertaking were used to define abusive. ${ }^{229}$ The tribunal held that the changes in the customs and tax regime were neither arbitrary nor discriminatory. ${ }^{230}$ The new tax measures adopted by the Moldovan government were rather of general application and therefore not directed specifically against the claimant. ${ }^{231}$ Besides, the tribunal found that the changes did not "place the claimant in a worse competitive position than any other similarly situated businesses in Moldova". 232 In this particular case, the claimant had not presented enough proof of a causal link between the tax measures in question and the decline of its business. ${ }^{233}$

\section{Bankruptcy law}

Where a state places a company into liquidation, this can obviously affect the foreign investor, since it results in a loss of control over the asset.

The introduction of unilateral insolvency by the administration or the incitement of this by preliminary requisitioning can thus constitute an expropriation which requires compensation for the investor. Without this intervention, a company would not have to be concerned about a suspension of payment nor would the investor be deprived of the right to exercise his property rights. In the ELSI case, the court did not find any expropriation because the financial position of the company was sufficiently damaged to justify liquidation. ${ }^{234}$ The causal link between the acts of the state (set in liquidation by summons) and the disappearance of the use of property rights was thus lacking.

\footnotetext{
${ }^{227}$ OECD International Investment Law: Understanding Concepts and Tracking Innovations. A Companion Volume to International Investment Perspectives (OECD, 2008) 57, paras 1 and 7.

${ }^{228}$ Link-Trading Joint Stock Company v Moldova, above n 205, para 64.

${ }^{229}$ Ibid.

${ }^{230}$ Ibid, para 72

231 Ibid.

232 Ibid, para 74.

233 Ibid, para 91.

${ }^{234}$ Elettronica Sicula S.p.A. (ELSI) (United States v Italy), above n 162, para 9.
} 
The ELSI case raised the question whether a requisitioning of the plant and assets of an Italian company (ELSI) based in Sicily but owned by United States corporations caused the bankruptcy of ELSI and thus violated substantive rights protected by the FCN Treaty $^{235}$ in force between the two parties to the dispute. ${ }^{236}$ The Court held that ELSI was already formally bankrupt under Italian law before the requisition order had taken place. ${ }^{237}$ Thus the requisitioning of the plant was not the principal cause for the bankruptcy of ELSI as well as the failure of its orderly liquidation plan, and did not constitute a violation of the United States shareholders" rights to "control and manage" ELSI under the FCN Treaty. It is clear that no right of control and management would have remained protected under the Treaty if ELSI were insolvent before the requisition was ordered. Therefore, the claim of the United States was dismissed as the Court reached the conclusion that "what really deprived Raytheon and Machlett, as shareholders, of their right to dispose of real property of ELSI, was not the requisition but the precarious financial state of ELSI, ultimately leading inescapably to bankruptcy." 238

In contrast, it is notable for example that the ASEAN Agreement ${ }^{239}$ contains a provision that refers to the protection against the abuse of the process of liquidation. Thus Article IV(1) of the Agreement states:

Each contracting party shall, within its territory, ensure full protection of the investments made in accordance with its legislation by investors of the other Contracting Parties and shall not impair by unjustified or discriminatory measures the management, maintenance, use, enjoyment, extension, or disposition or liquidation of such investments.

In Yaung Chi Oo Ltd v Myanmar ${ }^{240}$ the claimant had argued that an act of taking took place as a result of the liquidation proceedings before the Myanmar courts. The tribunal

\footnotetext{
${ }^{235}$ Treaty of Friendship, Commerce and Navigation (United-States-Italy) (2 June 1948).

${ }^{236}$ Elettronica Sicula S.p.A. (ELSI) (United States $v$ Italy, above n 162, para 10.

${ }^{237}$ Ibid, paras 85-93.

${ }^{238}$ Ibid, para 135.

239 ASEAN Agreement for the Promotion and Protection of Investments (ASEAN Agreement) (signed 15 December 1987) (1988) 27 ILM 612, III Compendium II 293.

${ }^{240}$ Yaung Chi Oo Trading Pte Ltd $v$ Government of the Union of Myanmar (Award) (2003) ASEAN Arbitral Tribunal 42 ILM 540.
} 
disagreed with the argument. Indeed, a taking may not take place solely because of a liquidation ordered by a court.

A recent verdict of an UNCITRAL tribunal in a dispute between Saluka Investments BV (The Netherlands) and the Czech Republic exemplifies the clash between the provisions of an investment treaty and the routine exercise of regulatory powers of the host state. ${ }^{241}$ The case arose from the proceedings that were the consequences of reorganisation and privatisation of the Czech banking sector which was done by selling IPB, one of the key players in the Czech banking sector, to a corporation within the Nomura group. Following this, Nomura sold the bought shares to one of the auxiliary parties, Saluka Investments BV. IPB around this time was on the brink of bankruptcy, due to negligence and its liberal lending policy, and was hence put into obligatory administration by the Czech government. The Czech government decided to sell IPB to another Czech company, ESOB. This decision sparked controversy among Nomura shareholders as they were stakeholders for over $46 \%$ of IPB shares. Following this, Nomura initiated an arbitration claiming loss of investments and asserted that the government measures were a bid to expropriate, while the Czech Republic deemed their measures to be "permissible regulatory actions". ${ }^{242}$ The tribunal was presented with the challenge of deciding on whether the government measures in this case were lawfully admissible under Article 5 of the Agreement on Encouragement and Reciprocal Protection of Investments between the Kingdom of the Netherlands and the Czech and Slovak Federal Republic. ${ }^{243}$ Article 5 of the BIT states:

Neither Contracting Party shall take any measures depriving, directly or indirectly, investors of the other Contracting Party of their investments unless the following conditions are complied with:

(a) the measures are taken in the public interest and under due process of law;

(b) the measures are not discriminatory;

(c) the measures are accompanied by provision for the payment of just compensation. Such compensation shall represent the genuine value of the investments affected and shall, in order to be effective for the claimants, be paid and made transferable, without undue delay, to the country designated by the claimants concerned and in any freely convertible currency accepted by the claimants.

\footnotetext{
${ }^{241}$ Saluka Investments BV (the Netherlands) $v$ the Czech Republic, above n 67.

242 Ibid, para 250.

243 Agreement on Encouragement and Reciprocal Protection of Investments (the Kingdom of the Netherlands and the Czech and Slovak Republic) (1975).
} 
The tribunal held that in imposing the forced administration of IPB on 16 June 2000 the Czech Republic adopted a measure that was valid and permissible and within its regulatory powers, notwithstanding that the measure had the effect of eviscerating the investment of Saluka in IPB. ${ }^{244}$ Explaining the permissibility of regulatory actions by governments in general international law, the Arbitral Tribunal stated that: ${ }^{245}$

Article 5 imports into the Treaty the customary international law notion that a deprivation can be justified if it results from the exercise of regulatory actions aimed at the maintenance of public order.

The Tribunal went on to add: ${ }^{246}$

It is now established in international law that States are not liable to pay compensation to a foreign investor when, in the normal exercise of their regulatory powers, they adopt in a non-discriminatory manner bona fide regulations that are aimed at the general welfare.

In taking into account all of the above considerations; the important issues to note are that an order of liquidation incited by the government cannot constitute an expropriation which implies compensation for the investor when foreign companies are already in a failing situation. It is important to list out in treaties and agreements the permissible regulatory actions regarding procedures of liquidation so that there are no disputes or conflicts arising out of such issues.

\section{$3 \quad$ Environmental law}

Environmental protection is a particularly ambiguous issue because the foreign investors can, in this regard, have contradictory interests. On the one hand, it could be said that certain investors seek host countries with lower environmental standards, in order to make more profits than in their country of origin. On the other hand, the investors would seek to establish themselves within a sufficiently healthy environmental framework to be able to attract social capital and, very often, in order to sell their products in their home country.

\footnotetext{
${ }^{244}$ Saluka Investments BV (the Netherlands) v the Czech Republic, above n 67, para 276.

245 Ibid, para 254.

${ }^{246}$ Ibid, para 255.
} 
Regardless of the validity of each of these theories, environmental protection, like the other public policies, is of interest to international investment law. The concept of environmental protection is broad because it includes concepts of the preservation of the quality of the air, water, and soil; the sustainable use of natural resources; the preservation of human, animal and plant life and health, and of the ecosystem more generally. ${ }^{247}$ The basis of environmental regulation policy is therefore based on these key issues. 1972 is often given as the birth date of modern international environmental law, when countries gathered for the United Nations Stockholm Conference on the Human Environment. ${ }^{248}$ Since then, hundreds of international environmental agreements have been concluded at bilateral, regional and global levels. States have therefore an obligation to take regulatory measures with the purpose of protecting the environment under both customary and conventional international law. These cover areas such as biodiversity, climate change and protection of the ozone layer among others. ${ }^{249}$ The protection of environment has gradually emerged as a new issue in several BITs. Indeed, some agreements have reiterated the authority of national governments to design and implement measures to safeguard certain values such as the environment.

The investor could encounter unforeseeable difficulties in environmental law given the interpretation of a growing number of courts of arbitration, if the interpretations are standards of general application.

Environmental protection applies not only to states but also to private non-state actors such as corporations. It concerns many acts and can affect investors in several ways. The measures designed to protect the environment are applicable from the establishment of the investment, but may be unknown to the investor because of promises of exemption or exemptions previously allocated but subsequently withdrawn, for example. Alternatively, the foreign investor may be unaware of such measures due to lack of clarity, false or contradictory information provided by the legal administration. In another situation, the measures of protection of the environment may be introduced $a$ posteriori and differ from the initial expectations of the investor.

\footnotetext{
${ }^{247}$ UNCTAD Environment (United Nations Publications, New York and Geneva, 2001) 9-10.

${ }^{248}$ Declaration of the United Nations Conference on the Human Environment (Stockholm Declaration) (5 12 June 1972) UN Doc A/CONF/48/14/REV 1 reprinted in 11 ILM 1416 (1972).

${ }^{249}$ See generally, Sands, Philippe Principles of International Environmental Law (2ed, Cambridge University Press, Cambridge, 2003) Chapters 8-14.
} 
Therefore, the relationship and the issues that may arise between investment protection and provisions of environmental protection in IIAs will be illustrated taking into account some provisions of investment agreements and the case law with a particular focus on the issues of expropriation, stabilisation and compensation. Host states grant themselves the right to interfere when, for example, multinational corporations cause environmental pollution. The regulatory right of the state might prevent a foreign investor from harmful decisions protecting the environment. ${ }^{250}$

\section{(a) Scope of coverage of environmental provisions in investment agreements}

The protections that can be the basis for a dispute over environmental regulation under BITs, NAFTA or plurilateral agreements like the ECT are generally standards of treatment such as national treatment and most-favoured nation treatment as well as prohibitions of expropriation.

A certain number of standards of protection regarding the environment included in IIAs need to be examined. Four categories can be distinguished: ${ }^{251}$ (1) the responsibility of governments or enterprises with regard to environmental protection; (2) the regulatory power of states to take measures for the protection of health and environment; (3) the avoidance of relaxation of environmental standards as a means of attracting FDI; and (4) the promotion, development and transfer of environmentally sound technologies and management practices. Thus, such issues which can be found as provisions in free trade agreements or investment treaties might be breached and consequently lead to an arbitration dispute. Therefore, it is of interest to mention several provisions which address environmental concerns.

First of all, some agreements like the Energy Charter Treaty contain provisions regarding the liability of governments or corporations for violations of environmental norms. The ECT specifically states that each party is required to "strive to minimize in an economically efficient manner harmful Environmental Impacts occurring either within or

\footnotetext{
${ }^{250}$ M Sornarajah The International Law on Foreign Investment, n 116, 125.

${ }^{251}$ UNCTAD Key Terms and Concepts in IIAs: A Glossary, above n 115, 61.
} 
outside its Area from all operations within the Energy Cycle in its Area, taking proper account of safety."252

Also, a few investment treaties affirm the sovereign right of the parties to an agreement to take appropriate environmental protection measures. An example of such a provision can be found in NAFTA in its Article 1114 (1):

Nothing in this Chapter shall be construed to prevent a Party from adopting, maintaining or enforcing any measure otherwise consistent with this Chapter that it considers appropriate to ensure that investment activity in its territory is undertaken in a manner sensitive to environmental concerns.

In addition, Article 1106 (6) of NAFTA stipulates, with respect to provisions on performance requirements, a specific exception for environmental measures:

Provided that such measures are not applied in an arbitrary or unjustifiable manner, or do not constitute a disguised restriction on international trade or investment, nothing in paragraph 1(b) or (c) or 3(a) or (b) shall be construed to prevent any Party from adopting or maintaining measures, including environmental measures:

[...]

(b) necessary to protect human, animal or plant life or health; or

(c) necessary for the conservation of living or non-living exhaustible natural resources.

In a similar manner to the Article 1114 (1) of NAFTA, another type of provision may stress an exception for environmental measures that applies to all provisions of an investment agreement. Annex I(III)(1) of the BIT between Canada and Uruguay ${ }^{253}$ reads:

Nothing in this Agreement shall be construed to prevent a Contracting Party from adopting, maintaining or enforcing any measure otherwise consistent with this Agreement that it considers appropriate to ensure that investment activity in its territory is undertaken in a manner sensitive to environmental concerns.

Some agreements discourage the lowering of domestic standards as a means of attracting FDI. Accordingly, the new Canadian model BIT (CAFTA) ${ }^{254}$ and the CanadaChile Free Trade Agreement provides in this regard that: ${ }^{255}$

\footnotetext{
${ }^{252}$ Energy Charter Treaty (ECT) above n18, Article 19(1). See further Clare Shine "Environmental Protection under the Energy Charter Treaty" in Thomas Wälde (ed) The Energy Charter Treaty: A Gateway to East-West Trade Relations (Kluwer Law International, London, 1996) 520.

${ }^{253}$ Agreement for the Promotion and Protection of Investments (Canada-Uruguay) (29 October 1997). Available at: http://www.unctad.org/sections/dite/iia/docs/bits/canada_uruguay.pdf (Accessed 22 September 2008).
} 
The Parties recognize that it is inappropriate to encourage investment by relaxing domestic health, safety or environmental measures. Accordingly, a Party should not waive or otherwise derogate from, or offer to waive or otherwise derogate from, such measures as an encouragement for the establishment, acquisition, expansion or retention in its territory of an investment of an investor. If a Party considers that the other Party has offered such an encouragement, it may request consultations with the other Party and the two Parties shall consult with a view to avoiding any such encouragement.

The above provision, not defining the term "environmental measures," seems to cover any law, regulation or administrative decision regulating environmental matters in the territory of the contracting parties. The clause addresses the waiving or relaxing of "any" environmental measure or offering to do so in order to attract or maintain an investment. Thus, it would be unnecessary to demonstrate a continuous tendency of behavior by a contracting party in violation of the commitment.

The 1994 Asia-Pacific Economic Cooperation (APEC) Non-Binding Investment Principles have stated environmental measures under its investment incentives provision. They read as follows: "Member economies will not relax health, safety, and environmental regulations as an incentive to encourage foreign investment."256

Finally, one must be aware of the transfer of environmentally sound technologies and the diffusion and utilisation of sound environmental management practices. ${ }^{257} \mathrm{~A}$ few IIAs and other international instruments address this issue. This facet as well as the general protection of environment is generally referred to with respect to the responsibility of both host countries and foreign companies. For example, Article 19 concerning environmental aspects of the Energy Charter Treaty contains an extensive list of matters that the contracting parties should do in pursuit of sustainable development. Inter alia, they should "encourage favourable conditions for the transfer and

\footnotetext{
${ }^{254}$ Canadian Model BIT - Agreement Between Canada and for the Promotion and Protection of Investments (2004) above n 198, Article 11.

${ }^{255}$ Canada-Chile Free Trade Agreement (signed 5 December 1996, entered into force 5 July 1997) Article G-14 (2). Available at: http://www.sice.oas.org/trade/chican_e/chcatoc.asp (Accessed 22 September 2008). The same provision appears in Article 1114 (2) of the NAFTA and Article 9-15 (2) of the Mexico-Chile Free Trade Agreement (1998).

${ }^{256}$ For other examples of IIAs dealing with this type of environmental regulatory restrictions, see MexicoCosta Rica Free Trade Agreement (1994) articles 13-16; Mexico-Nicaragua Free Trade Agreement (1992) articles 16-14 and Mexico-Chile Free Trade Agreement (1998) articles 9-15; also Colombia-MexicoVenezuela Free Trade Agreement (1900) articles 17-13.

${ }^{257}$ See UNCTAD Environment, above n 247, 41-66.
} 
dissemination of such technologies consistent with the adequate and effective protection of Intellectual Property rights.",258

The preceding review of provisions that address the linkage between the environment and FDI reflects, as is the case with the protection of the environment in general, the recognition of the need to address this issue in international agreements. Indeed, as the analysis demonstrates, there is room to strengthen relevant provisions in the sense of awareness to encourage multinational enterprises to develop their activities in an environmentally friendly manner.

The relationship between the investment agreement and other international treaties dealing with environmental matters is not often mentioned. However, various United States agreements refer to multilateral environmental treaties to which the Parties are both party. For example, Article 19.8 of the United States-Australia Free Trade Agreement (FTA) states: $:^{259}$

\begin{abstract}
The Parties recognise that multilateral environmental agreements to which they are both party play an important role, globally and domestically, in protecting the environment and that their respective implementation of these agreements is critical to achieving the environmental objectives of these agreements. Accordingly, the Parties shall continue to seek means to enhance the mutual supportiveness of multilateral environmental agreements to which they are both party. The Parties shall consult regularly with respect to negotiations in the WTO regarding multilateral environmental agreements.
\end{abstract}

In consequence, a number of international investment agreements recognise the right of states to adopt certain measures designed to ensure that investment activity is undertaken in a manner sensitive to environmental concerns. The previous listing of provisions from different treaties is illustrative of this reality.

Finally and interestingly, a draft article of an agreement between the EU and the Pacific members of the African, Caribbean and Pacific Group of States (ACP) countries of June 2006 takes a step forward in narrowing the scope of regulatory measures as noncompensable expropriations: ${ }^{260}$

\footnotetext{
${ }^{258}$ Energy Charter Treaty (ECT) above n 18, Article 19 (1) (h).

${ }^{259}$ United States-Australia Free Trade Agreement (entered into force on 1 January 2005).

${ }^{260}$ Draft Article 8.8(I) of the investment chapter in the context of the EU/PACP EPA negotiations, DG Trade G 1(D) (2006).
} 
Consistent with the right of states to regulate and the customary international law principles on police powers, bona fide, non-discriminatory regulatory measures taken by a Party that are designed and applied to protect or enhance legitimate public welfare objectives, such as public health, safety and the environment, do not constitute an expropriation under this Article.

If this draft article remains in the adoption of the final agreement, it would constitute an important new trend in foreign investment law and would possibly be more protective in acknowledging the exercise of the regulatory powers of host states.

\section{(b) Environment-related arbitral awards}

Environmental issues have arisen in a number of arbitrations under NAFTA and under BITs. It is interesting to now take a closer look at four disputes that have arisen under NAFTA provisions on investment. The cases introduced below were chosen because they are recent decisions and contain significant analysis of the issues and provide useful examples of how disputes have been resolved by tribunals. In these controversial investor-state disputes, developed states alleged a breach of environmental standards (environmental abuse) against foreign multinational corporations of other developed states parties to the treaty.

The main issue was to determine whether a regulatory interference to promote environmental interests resulted in a taking of property of the foreign investor. However, in the majority of these cases expropriation was not determined by the tribunals to have occurred.

When expropriation occurs, it usually results in the deprivation of the property of a foreign investor. Nonetheless, under the majority of international investment agreements an expropriation is considered to be lawful if three conditions are respected: the taking of the investment must be for a public purpose, in a non-discriminatory manner and with compensation. In addition, another form of taking, namely indirect expropriation has become increasingly important. Indirect expropriations involve the effective loss of management, use or control, or a significant depreciation of the value of the assets of a foreign investor. ${ }^{261}$

\footnotetext{
${ }^{261}$ UNCTAD Taking of Property, above n 123, 4.
} 
The Methanex case $^{262}$ arose out of a dispute between a Canadian corporation, Methanex, and the state of California. Methanex claimed that two California environmental measures which banned a gasoline additive (MTBE) amounted to a violation of the United States obligations under NAFTA, especially that the California law violated national treatment, was inconsistent with the fair and equitable treatment article and constituted indirect expropriation. The Methanex case has adopted what Mann describes a "modern regulatory approach to the police powers concept" that: ${ }^{264}$

\begin{abstract}
As a matter of general international law, a non-discriminatory regulation for a public purpose which affects, inter alios, a foreign investor or investment is not deemed expropriatory and compensatory unless specific commitments had been given by the regulating government to then putative foreign investor contemplating investment that the government would refrain from such regulation.
\end{abstract}

The tribunal found that there was no indirect expropriation. The tribunal's final award dismissed all of Methanex's claims and rejected some of the findings in the Metalclad case in which regulatory measures were regarded to be expropriation and thus compensable. The exception for "specific commitments" given by the government echoes the reasoning in the Metalclad case. ${ }^{265}$ In finding that no promises were made regarding future regulation of MTBE, the tribunal noted that: $:^{266}$

\begin{abstract}
Methanex entered a political economy in which it was widely known, if not notorious, that governmental environmental and health protection institutions at the federal and state level, ... continuously monitored the use and impact of chemical compounds and commonly prohibited or restricted use of some of those compounds for environmental and/or health reasons.
\end{abstract}

In addition, the tribunal held that "from the standpoint of international law, the California ban was a lawful regulation and not an expropriation." ${ }^{267}$ It was also considered significant that the host state had made no commitments to Methanex not to

\footnotetext{
${ }^{262}$ Methanex Corp v United States of America, above n 69. See further, Philippe Khan and Thomas Wälde New Aspects of International Investment Law (Martinus Nijhoff Publishers, Leiden-Boston, 2007) 775-787.

263 Howard Mann The Final Decision in Methanex v United States: Some New Wine in Some New Bottles (IISD, Winnipeg, 2005) 6.

${ }^{264}$ Methanex Corp v United States of America, above n 69, Part IV, Chapter D, para 7.

${ }^{265}$ Metalclad Corporation v United Mexican States, above n 125.

${ }^{266}$ Methanex Corp v United States of America, above n 69, Part IV, Chapter D, para 9.

${ }^{267}$ Ibid, para 15.
} 
amend its regulatory framework. Thus it seems that unless the host state gives the investor a stabilisation commitment prior to its investment, the investor will bear the risk of legally enacted changes in the regulation of a host state.

NGOs have played an increased and influential role in defending environment concerns via amicus curiae submissions. It is relevant to point out a few arguments raised by an environmental NGO, namely the IISD ${ }^{268}$ Hence, investor-state arbitrations do not shield investors from regulatory measures producing a negative impact on their activities. ${ }^{269}$ Furthermore, investors are presumed to be aware of the environment in which they are investing. ${ }^{270}$ The state can take regulatory measures via the protection of the environment and the promotion of sustainable development which do not constitute the forms of regulation that a host state is allowed in relation to foreign investors and investments. ${ }^{271}$ The Preamble and objectives of NAFTA and the few international investment law arbitrations that have decided on this issue emphasise this notion. ${ }^{272}$

Investors who have been denied permits on alleged environmental grounds have prevailed in a number of arbitrations including the Metalclad case. Metalclad purchased a Mexican company (COTERIN) in order to develop and operate a hazardous waste landfill that it constructed in the municipality of Guadalcázar. Although COTERIN was the owner of permits to construct and operate the landfill delivered by the federal government of Mexico and the state government of San Luis Potosi, the municipality of Guadalcázar interfered by denying a municipal construction permit to COTERIN and in declaring the landfill to be an ecological reserve. Hence, Metalclad introduced an action under the NAFTA and claimed that an ecological decree promulgated after the claim was made, violated Article 1110 requiring compensation for expropriation. The tribunal found a violation of NAFTA Article $1110^{273}$ and stated that in order to decide on an indirect

\footnotetext{
${ }^{268}$ In the Arbitration under Chapter 11 of the North American Free Trade Agreement and the UNCITRAL Arbitration Rules between Methanex Corporation and United States of America Amicus Curiae Submissions by the International Institute for Sustainable Development (IISD) (9 March 2004).

${ }^{269}$ Methanex Corporation and United States of America, above n 102, 1.

${ }^{270}$ Ibid.

271 Ibid, 7

272 Ibid.

${ }^{273}$ Metalclad Corporation v United Mexican States, above n 125, para 112.
} 
expropriation, it "need not decide or consider the motivation, nor intent of the adoption of the Ecological Decree". ${ }^{274}$ The Tribunal held: ${ }^{275}$

Expropriation under NAFTA includes not only open, deliberate and acknowledged takings of property, such as outright seizure or formal or obligatory transfer of title in favour of the host State, but also covert or incidental interference with the use of property which has the effect of depriving the owner, in whole or in significant part, of the use of reasonably-to-be expected economic benefit of property even if not necessarily to the obvious benefit of the host State.

The broad definition of expropriation applied by the arbitral tribunal has not been used or adopted in other awards. ${ }^{276}$ In this particular case, an indirect expropriation was found as a result of the denial of a construction permit which amounted to indirect expropriation. ${ }^{277}$ Evidently, the mere denial of a construction permit did not constitute the only reason that led the tribunal to the finding of an expropriation. ${ }^{278}$ To a certain extent the disappointment of legitimate investor expectations created by the environmental measure of the host state was decisive for this result. ${ }^{279}$ In this case, the Federal government guaranteed that the project of the investor for a landfill had conformed to all relevant environmental regulations. ${ }^{280}$ It was against this background that the subsequent local and regional measures of denying the construction permit and declaring the land in question an ecological zone were considered to be indirect expropriation: ${ }^{281}$

\begin{abstract}
By permitting or tolerating the conduct of Guadalcazar in relation to Metalclad which the Tribunal has already held amounts to unfair and inequitable treatment breaching Article 1105 and by thus participating or acquiescing in the denial to Metalclad of the right to operate the landfill, notwithstanding the fact that the project was fully approved and endorsed by the federal government, Mexico must be held to have taken a measure tantamount to expropriation in violation of NAFTA Article 1110(1).
\end{abstract}

If a contract or a treaty has been found to be breached by a tribunal, then compensation is the most likely remedy that will be awarded to the claimant. Recently,

\footnotetext{
${ }^{274}$ Metalclad Corporation v United Mexican States, above n 125, para 111.

${ }^{275}$ Ibid, para 103.

${ }^{276}$ Violations of Article 1110 found in other awards include: SD Myers v Canada, above n 146, Pope and Talbot v Canada, above n 148, paras 96-105; Marvin Feldman v Mexico, above n 155, paras 96 et seq.

${ }^{277}$ Metalclad Corporation v United Mexican States, above n 125, para 107.

${ }^{278}$ August Reinisch "Expropriation”, above n 142, 455.

${ }^{279}$ Ibid.

${ }^{280}$ Ibid, 456.

${ }^{281}$ Metalclad Corporation v United Mexican States, above n 125, para 104.
} 
there has been discussion over whether the interference of a government with an investment should also be taken into account in the determination of the value of the compensation to be awarded. In Compania del Desarrollo de Santa Elena S.A v Costa Rica, ${ }^{282}$ a dispute arising out from a United States-Costa Rica BIT and resolved under ICSID rules, there was no disagreement over the fact that a direct expropriation took place (in 1978, Costa Rica issued an expropriation decree for Santa Elena aiming at declaring it a preservation site even though the claimant intended to develop a tourist resort) or that it was for valid purpose (the protection of biodiversity). However, the amount of compensation owed by Costa Rica to the claimant constituted the main disagreement between the parties. Costa Rica argued that setting the amount of compensation too high would discourage states (particularly those from the developing world) from adopting environmental objectives, and also noted that when it made the expropriation it had acted in accordance with its obligations under multilateral environmental agreements. The panel expressly indicated that the environmental purpose had no influence and concluded that the standard of compensation could not be affected by the reasons for making the expropriation. The panel held that: ${ }^{283}$

\begin{abstract}
While an expropriation or taking for environmental reasons may be classified as a taking for a public purpose, and thus be legitimate, the fact that the property was taken for this reason does not affect either the nature or the measure of the compensation to be paid for the taking. That is, the purpose of protecting the environment for which the Property was taken does not alter the legal character of the taking for which adequate compensation must be paid. The international source of the obligation to protect the environment makes no difference.
\end{abstract}

It also added: ${ }^{284}$

Expropriatory environmental measures - no matter how laudable and beneficial to society as a whole - are, in this respect, similar to any other expropriatory measures that a state may take in order to implement its policies: where property is expropriated, even for environmental purposes, whether domestic or international, the state's obligation to pay compensation remains.

\footnotetext{
${ }^{282}$ Compaňia Del Desarrollo de Santa Elena, SA v Republic of Costa Rica, above n 146.

283 Ibid, para 71.

${ }^{284}$ Ibid, para 72.
} 
It is noticed that the arbitral tribunal was reluctant to have regard to international environmental obligations in determining the level of compensation to be paid for a lawful expropriation.

In $S D$ Myers, ${ }^{285}$ a United States company which was involved in the remediation of toxic waste challenged the decision of Canada to ban the trans-boundary shipment of toxic waste to the United States for processing. The company claimed that Canada violated NAFTA Chapter $11 .^{286}$ The tribunal found Canada in breach of the national treatment standard and the minimum international standard of treatment. ${ }^{287}$ This decision also held that Canada did not breach Chapter 11 with respect to expropriation (Article 1110). ${ }^{288}$ An interim order which is no longer in effect in Canada was the measure on which the tribunal based its decision. The tribunal recognised the right of NAFTA members to "establish high levels of environmental protection. They are not obliged to compromise their standards merely to satisfy the political or economic interests of other states. ${ }^{289}$ Accordingly, the award confirms that NAFTA members retain the ability to regulate the safe movement and disposal of hazardous wastes, including PCB wastes which was subjected to the ban.

When environmental measures may justify non-compensation under expropriation case law, one can notice that the deficiency in jurisprudence is not sufficiently apparent to draw guidance. This area is therefore subject to many controversies. ${ }^{290}$

Stabilisation clauses may be used by investors to seek to exclude subsequently introduced environmental regulations. ${ }^{291}$ Such clauses are any provision of a contract signed between a state and a foreign corporation in which the state promises that no future changes in law will be applied to the investment. ${ }^{292}$ Stabilisation clauses are therefore aimed at freezing the law relevant to the investment.

\footnotetext{
${ }^{285}$ SD Myers Inc v Government of Canada, above n 146.

${ }^{286}$ Ibid, paras 129-143.

${ }^{287}$ Ibid, para 256 and para 268.

${ }^{288}$ Ibid, paras $287-288$.

${ }^{289}$ Ibid, paras 220 and 247.

${ }^{290}$ Howard Mann and Konrad Von Moltke NAFTA's Chapter XI and the Environment (IISD, Winnipeg, Manitoba, 1999) 39-40; Martin J Wagner "International Investment, Expropriation and Environmental Protection" (1999) 29 Golden Gate U L Rev 465; Gantz A David "Reconciling Environmental Protection and Investor Rights under Chapter 11 of NAFTA" (2001) 31 Envtl L Rep 10646.

${ }^{291}$ M. Sornarajah The International Law on Foreign Investment, above n 116, 180

${ }^{292}$ Philippe Khan and Thomas Wälde New Aspects of International Investment Law, above n 262, 257.
} 
Wälde and N'Di consider that: "stability of key investment conditions responsible for the economic and financial performance of the investment venture is at the heart of investor concern". ${ }^{293}$ The above authors also note that an investor may be desirous to include a stabilisation clause to the contract when other issues are at stake: ${ }^{294}$

Perhaps most relevant at the moment is the imposition of new environmental obligations by subsequent regulation or by an administrative/judicial ruling re-interpreting existing law on which, arguably, the investment decision may to some extent have been based.

Some authors point out that a stabilisation clause could even cover environmental regulations without explicitly referring to it. For example, a stabilisation of the fiscal regime could cover market-based environmental measures. ${ }^{295}$

Sornarajah contends that despite a contractual agreement denying the application of new standards to the investment, it cannot "fetter the legislative sovereignty of the states from extending its control over the investment". ${ }^{296}$ Calling the binding nature of stabilisation clauses into question, he suggests that a state cannot waive or limit its own sovereignty in such a manner. Thus stabilisation clauses: ${ }^{297}$

may not serve as anything more than a comforter to the foreign investor, who may derive some security from the belief that there is a promise secured from the state not to apply its future legislation to the agreement.

Nevertheless, despite the academic debate, tribunals have consistently upheld stabilisation clauses. ${ }^{298}$ In conclusion, even if a stabilisation clause may not prevent a state from changing legislation, the breach of such a clause is likely to lead to a requirement to compensate the investor for losses incurred. Stabilisation clauses might

\footnotetext{
${ }^{293}$ Thomas Wälde and George N'Di “Stabilising International Investment Commitments: International Law Versus Contract Interpretation" (1996) CEPMLPIJ 1, 5. Available at http://www.dundee.ac.uk/cepmlp/infoserv/Downloads_Free/PP13.pdf (last accessed 15 September 2008). ${ }^{294}$ Ibid.

${ }^{295}$ Gaëtan Verhoosel "Foreign Direct Investment and Legal Constraints on Domestic Environmental Policies: Striking a "Reasonable" Balance between Stability and Change" (1998) 29 (4) Law \& Pol'y Int'l Bus 453, 457.

${ }_{296}$ M Sornarajah The International Law on Foreign Investment, above n 116, 180.

${ }^{297}$ Ibid, 408.

298 Gaëtan Verhoosel "Foreign Direct Investment and Legal Constraints on Domestic Environmental Policies: Striking a "Reasonable", above n 295, 456. Kuweit, Government v American Independent Oil Company (Aminoil), above n 42; Texaco Overseas Petroleum Co v Libyan Arab Republic, above n 36; Pacific Properties (Middle East) Ltd (SPP) v Arab Republic of Egypt, above n 163.
} 
take two different main forms. According to the so-called freezing clauses, the obligation to compensate will arise when a regulatory change is applied to the investment project, whilst under economic equilibrium clauses this obligation is elicited by regulatory measures that affect the fiscal stability. Under the stabilisation clause, the limit beyond which the host government must compensate is significantly lower than that which is pertinent to regulatory takings under general international law (changes to the "economic equilibrium" of the project rather than "substantial deprivation" of property rights). ${ }^{299}$

The protection offered to investors may limit the ability of governments to regulate investment for the protection of the environment, natural resources and other social goods, and to ensure that foreign investment contributes to overall national development goals. Indeed, regulators may face uncertainty given the lack of transparency in arbitration and the lack of consistency of tribunal decisions.

\section{$4 \quad$ Labour law}

The labour law of the host state is also of great practical interest. Foreign investors often have activities with a strong labour component in the host state, generally because the production costs tend to be lower than in their home state. One example is the establishment of a European automotive industry in countries where social costs are less, such as: Volkswagen in Czech Republic, Renault in Romania and Mercedes-Benz in South Africa.

Accordingly, the legal system applicable to the employees would be of interest to the investors. It is thus possible that international investment law is invoked against measures taken by the host state regarding the labour laws. This is true especially for the standards relating to minimum wage, working hours or social contributions. However, the host state is unlikely to be sanctioned for measures in this field if the increased costs are unforeseen to the investor, as it is a normal investment risk. More particularly, such a measure would be by nature non-discriminatory and thus in conformity with the principle of the national treatment as well with the most-favoured nation treatment. Moreover, the standards of work are generally known to the point that one could reproach the investor

${ }^{299}$ Ibid. 
for not being sufficiently informed about the ruling legislation, rather than to sanction the host country for a supposed opacity in this respect.

Employment and labour provisions are relatively uncommon in IIAs. The most comprehensive international instruments in the area of the development of labour and social policy standards need to be considered. ${ }^{300}$ Indeed, discussions upon the conduct of activities of MNEs led to a definition of their relation with host countries, especially those in the developing world. Therefore, two bodies of rules emerged in the area of employment practices. Labour standards as well as the issue of the responsibility of enterprises are first contained in the International Labour Organisation (ILO) Tripartite Declaration of Principles Concerning Multinational Enterprises and Social Policy (the ILO Declaration) ${ }^{301}$ adopted in 1977 as supplemented by the ILO Declaration on Fundamental Principles and Rights at Work ${ }^{302}$ of 1998. The 1998 Declaration sets core labour standards not specific to foreign investment and provides to its ILO members the obligation to observe four fundamental rights in its Article 2:

(a) freedom of association and the effective recognition of the right to collective bargaining;

(b) the elimination of all forms of forced or compulsory labour;

(c) the effective abolition of child labour; and

(d) the elimination of discrimination in respect of employment and occupation.

Second, labour standards are also included in the OECD Guideline on Employment and Industrial Relations (the OECD Guideline) ${ }^{303}$ adopted in 1976 and revised in 2000. Since the OECD Guideline is less detailed in its content on Employment and Industrial

\footnotetext{
${ }^{300}$ UNCTAD Employment (United Nations Publications, New York and Geneva, 2000); Peter T Muchlinsky Multinational Enterprises and the Law, above n 187, Chapter 13.

${ }^{301}$ ILO Tripartite Declaration of Principles Concerning Multinational Enterprises and Social Policy (adopted 16 November 1977 and amended in November 2000) 17 ILM 422.

Available at: http://www.ilo.org/public/employment/multi/download/english.pdf (accessed 06 October 2008). See further, Bob Hepple "New Approaches to International Labour Regulation" (1997) 26 Ind L J 353.

${ }^{302}$ ILO Declaration on Fundamental Principles and Rights at Work (June 1998) 37 ILM 1233. Available at: http://www.ilo.org/dyn/declaris/DECLARATIONWEB.static_jump?var_language=EN\&var_pagename=D ECLARATIONTEXT (accessed 06 October 2008).

303 OECD Guidelines for Multinational Enterprises (OECD, Paris, 2000) available at: http://www.olis.oecd.org/olis/2000doc.nsf/LinkTo/NT00002BE6/\$FILE/00085743.PDF (accessed 06 October 2008).
} 
Relations as part of a general guideline in all major areas of business than the ILO Declaration, more attention will be drawn to the latter.

Both codes are voluntary in nature ${ }^{304}$ and thus provide recommendations and nonlegally binding norms for the governments, employers and workers organisations of both home and host countries and to MNEs. ${ }^{305}$ The main areas covered by the ILO Declaration are employment, training, conditions of work and life and industrial relations.

Three main issues covered under the employment issue are namely employment promotion, equality of opportunity and treatment and security of employment. Thus, the promotion of employment is asserted to be important by the ILO Declaration. Governments should "declare and pursue as a major goal, an active policy designed to promote full, productive and freely chosen employment", 306 and MNEs, "particularly when operating in developing countries, should endeavour to increase employment opportunities and standards, taking into account the employment policies and objectives of the governments, as well as security of employment and the long-term development of the enterprise". 307

Also, the Declaration provides that "all governments should pursue policies designed to promote equality of opportunity and treatment in employment, with a view to eliminating any discrimination based on race, colour, sex, religion, political opinion, national extraction or social origin." ${ }^{308}$ Equally, pursuing discriminatory policies ${ }^{309}$ by MNEs should never be encouraged by governments. For example, one current form of discrimination is the failure to provide equal pay for men and women despite the fact that the European Union defends the view that men and women are of equal worth. ${ }^{310}$ It is recommended that governments study the impact of MNEs on employment and develop suitable policies to deal with the employment and labour market impacts on MNE

\footnotetext{
${ }^{304}$ ILO Declaration, above n 302, para 7; OECD Guidelines, above n 303, Section 1 Concepts and Principles para 1.

${ }^{305}$ ILO Declaration, above n 302, para 4.

${ }^{306}$ Ibid, para 13.

${ }^{307}$ Ibid, para 16.

${ }^{308}$ Ibid, para 21 and Convention No 111 and Recommendation No 111 concerning Discrimination in Respect of Employment and Occupation and Convention No 100 and Recommendation No 90 concerning Equal Remuneration for Men and Women Workers for Work of Equal Value.

${ }^{309}$ ILO Declaration, above n 302, para 23.

${ }^{310}$ See Article 141 EC Treaty guaranteeing that men and women should receive equal pay for equal work.
} 
operations. ${ }^{311}$ MNEs are encouraged to assume a leading role in promoting security of employment, particularly in countries where the discontinuation of operations is likely to accentuate long-term unemployment. ${ }^{312}$ Besides, MNEs and national enterprises should, through active manpower planning, "endeavour to provide stable employment for their employees and should observe freely negotiated obligations concerning employment stability and social security.",313

With regard to the training of workers from MNEs, the ILO Declaration encourages governments to develop national policies for vocational training and guidance, closely linked with employment. ${ }^{314}$ Thus, relevant training should be provided for all levels of employees in the host country to meet the need of the enterprise as well as the development policies of the country. It should develop generally useful skills and promote career opportunities. ${ }^{315}$

Under the conditions of work and life heading, the ILO Declaration applies the national treatment standard to wages, benefits and conditions of work: "Wages, benefits and conditions of work offered by multinational enterprises should be not less favourable to the workers than those offered by comparable employers in the country concerned." 316 Additionally, the Declaration states that "multinational enterprises, as well as national enterprises, should respect the minimum age for admission to employment or work in order to secure the effective abolition of child labour."317

Finally, the Declaration deals with five issues in relation to industrial relations: freedom of association and the right to organise, collective bargaining, consultation, examination of grievances, and the settlement of industrial disputes. The principle of national treatment is guaranteed to each area: "multinational enterprises should observe standards of industrial relations not less favourable than those observed by comparable employers in the country concerned.",318

\footnotetext{
${ }^{311}$ ILO Declaration, above n 302, para 24.

312 Ibid, para 25.

313 Ibid, para 27.

${ }^{314}$ Ibid, para 29 and Convention No. 142 and Recommendation No. 150 concerning Vocational Guidance and Vocational Training in the Development of Human Resources.

${ }^{315}$ ILO Declaration, above n 302, para 30.

${ }^{316}$ Ibid, para 33 .

${ }^{317}$ Ibid, para 36.

318 Ibid, para 41.
} 
The ILO has extensive mechanisms for supervising the application of its standards and Conventions. First, regular supervision is based on the obligation of governments which are members of the Conventions they have ratified to provide regular, periodic reports on measures taken. ${ }^{319}$ Secondly, special systems provide for ad hoc procedures and allow examination of complaints by employers or workers organisations and other governments concerning alleged failure by a country to apply a Convention it has ratified. $^{320}$

The emergence of the protection of labour standards in IIAs is quite recent and it is noticeable that the number of agreements addressing this issue is lower than the number of agreements dealing with environmental protection. Such a narrow reference to social matters will be identified in the following paragraph in bilateral investment treaties and investment provisions in trade agreements.

Frequently, labour concerns are incorporated in the BIT preambles through a political statement. For example, the BIT between Finland and Nicaragua states: ${ }^{321}$

The Government of the Republic of Finland and the Government of the Republic of Nicaragua, hereinafter referred to as the "Contracting Parties", ... agreeing that a stable framework for investment will contribute to maximising the effective utilisation of economic resources and improve living standards; recognising that the development of economic and business ties can promote respect for internationally recognised labour rights; ...

Several other BITs stress that the contracting parties must explicitly strive to abstain from relaxing labour standards as a means of attracting or maintaining investment in their territories. Article 6 of the BIT between Belgium and Ethiopia is illustrative of this kind of provision. ${ }^{322}$ This provision is complemented by a definition of the term "labour legislation": 323

\footnotetext{
319 International Labour Organisation Constitution, Article 22. Available at: http://training.itcilo.it/ILS/foa/library/constitution/indexconst_en.html (last accessed 03 December 2008). ${ }^{320}$ International Labour Organisation Constitution, Article 24.

${ }^{321}$ Agreement between the Government of the Republic of Finland and the Government of the Republic of Nicaragua on the Promotion and Protection of Investments (2003) Preamble (emphasis added).

${ }^{322}$ Agreement between the Belgian-Luxembourg Economic Union and the Federal Democratic Republic of Ethiopia on the Reciprocal Promotion and Protection of Investments (2003) Article 6. Available at: http://www.unctad.org/sections/dite/iia/docs/bits/BLEU-Ethiopie-eng.pdf (accessed 12 October 2008).

${ }_{323}$ Agreement on the Reciprocal Promotion and Protection of Investments (Belgo-Luxembourg Economic Union-Ethiopia) (2003) Article 16 Definitions.
} 
The terms "labour legislation" shall mean legislation of the Kingdom of Belgium, of the Grand Duchy of Luxembourg or of the Federal Democratic Republic of Ethiopia, or provisions thereof, that are directly related to the following internationally recognised labour rights:

a) the right of association;

b) the right to organise and bargain collectively;

c) a prohibition on the use of any form of forced or compulsory labour;

d) a minimum age for the employment of children;

e) acceptable conditions of work with respect to minimum wages, hours of work, and occupational safety and health.

It is recognised that each country has the right "to establish its own domestic labour standards and accordingly adopt or modify its labour legislation". ${ }^{324}$ However, it is also stated that each contracting party "shall strive to ensure" 325 that its legislation provides for labour standards consistent with the labour rights listed in the definition of "labour legislation" cited above, which are considered being internationally recognised labour rights. This refers to the obligations of each party derived from their membership of the ILO and the ILO Declaration on Fundamental Principles and Rights at Work.

Likewise, the United States Model BIT 2004, Article 13 reads as follows: ${ }^{326}$

1. The Parties recognize that it is inappropriate to encourage investment by weakening or reducing the protections afforded in domestic labour laws [...]

2. for purposes of this Article, "labour laws" means each Party's statutes or regulations, ${ }^{327}$ or provisions thereof that are directly related to the following internationally recognized labour rights:

(a) the right of association;

(b) the right to organize and bargain collectively;

(c) a prohibition on the use of any form of forced or compulsory labor;

(d) labour protections for children and young people, including a minimum age for the employment of children and the prohibition and elimination of the worst forms of child labor; and

\footnotetext{
${ }^{324}$ BIT between Belgium-Luxembourg and Ethiopia, above n, Article 6, 1.

${ }^{325}$ Ibid, Article 6, 2.

${ }^{326}$ Treaty between the Government of the United States of America and The Government of [Country] Concerning the Encouragement and Reciprocal Protection of Investment - US Model BIT (2004). Available at http://www.state.gov/documents/organization/38710.pdf (accessed 28 July 2008).

${ }^{327}$ For the United States, "statutes or regulations" for purposes of this Article means an act of the US Congress or regulation promulgated pursuant to an act of the US Congress that is enforceable by action of the federal government.
} 
(e) acceptable conditions of work with respect to minimum wages, hours of work, and occupational safety and health.

Provisions under BITs constitute interesting alternative tools to promote labour rights as well as social justice.

A number of regional FTAs, particularly found in the Americas, include a chapter on investment. Social provisions are also mentioned.

The United States-Chile FTA ${ }^{328}$ contains several preamble clauses that reference social issues. Indeed, the parties resolve to: ${ }^{329}$

CREATE new employment opportunities and improve working conditions and living standards in their respective territories;

BUILD on their respective international commitments and strengthen their co-operation on labour matters;

PROTECT, enhance, and enforce basic worker's rights;

$[\ldots]$

In addition, the United States-Chile FTA states that the Parties recognise that cooperation provides enhanced opportunities for the Parties to promote respect for the principles embodied in the ILO Declaration and the ILO Convention No 182 Concerning the Prohibition and Immediate Action for the Elimination of the Worst Forms of Child Labour (1999) ${ }^{330}$ and that the Parties agree to cooperate on labour issues under a Labour Cooperation Mechanism. ${ }^{331}$

The NAFTA text makes a few references to labour issues. The preamble of the main agreement includes two general objectives regarding labour: "create new employment opportunities and improve working conditions and living standards" and "protect, enhance and enforce basic worker's rights". Also, it is noteworthy that on the issue of a "no lowering of standards" clause, certain IIAs contain a clause whereby the

\footnotetext{
328 United States-Chile Free Trade Agreement (2003). Available at: http://www.ustr.gov/Trade_Agreements/Bilateral/Chile_FTA/Final_Texts/Section_Index.html_ (last accessed 28 November 2008).

${ }^{329}$ Ibid, Preamble.

${ }^{330}$ Ibid, Article 18.5. See also, United States-Peru Trade Protection Agreement (TPA) (2006) which contains in its Article 17.5 and Annex 17.5 the same provision.

${ }^{331}$ Ibid, Annex 18.5.
} 
parties agree not to compete for inward FDI by lowering employment standards. In this connection, Article 1114 of NAFTA is relevant in stressing that:

It is inappropriate to encourage investment by relaxing domestic health, safety or environmental measures. Accordingly, a Party should not otherwise derogate from, or offer to waive or otherwise derogate from, such measures as an encouragement for the establishment, acquisition, expansion or retention in its territory of an investment of an investor. If a Party considers that another party and the two parties shall consult with a view to avoiding such encouragement.

Though limited to health, safety and environmental measures, the approach of this provision can be adapted to employment issues in general, as well as to other emerging issues.

Similarly the very recent New Zealand-China FTA ${ }^{332}$ signed in 2008 provides a reference to social matters: ${ }^{333}$

Desiring to strengthen their economic partnership to bring economic and social benefits, to create new opportunities for employment and to improve the living standards of their peoples;

Disputes involving labour issues do not appear to have been addressed by any arbitral tribunal. However, the case Piero Foresti, Laura de Carli \& others $v$ South Africa, ${ }^{334}$ is a pending claim on affirmative action for black employees in South Africa. The claimants are several Italian citizens and a Luxembourg corporation that hold interests in South African granite quarrying companies. Four NGOs in coalition have filled a petition and hope to gain permission to comment on how the tribunal might consider the crucial domestic and international human rights issues that the case has raised. The claimants challenge the validity of the social transformation measures of the South African government under the Mineral and Petroleum Resources Development Act (MPRDA) of 2002 enacted for public policy reasons. ${ }^{335}$ One of them is the need to proactively redress the apartheid history of exploitive labour practices and the inequality

\footnotetext{
${ }^{332}$ New Zealand - China Free Trade Agreement (NZ-China FTA) (signed 7 April 2008). Available at: http://chinafta.govt.nz/1-The-agreement/2-Text-of-the-agreement/index.php (lat accessed 08 August 2009).

${ }^{333}$ Ibid, Preamble.

${ }^{334}$ Piero Foresti, Laura de Carli \& others $v$ South Africa Petition for Limited Participation as NonDisputing Parties in Terms of Articles 41(3), 27, 39 and 35 of the Additional Rules (ICSID) Case $\mathrm{ARB}(\mathrm{AF}) / 07 / 01$ (17 July 2009).

${ }^{335}$ Ibid, 8 para 4 Reasons for the Petition.
} 
in labour market black South Africans and other ethnic groups. ${ }^{336}$ The hearings for this case are currently scheduled for April 2010.

\section{$5 \quad$ State taking of property sector}

The taking of private assets by public authorities raises significant issues of international law, where such takings involve the assets of foreign investors. This section examines the concept of expropriation in the context of international law and IIAs. The focus of the analysis is twofold. First, different categories of takings are distinguished, addressing in particular the problem of the distinction between governmental measures that involve interference with the assets of foreign investors, yet do not require compensation, and those that do require compensation. Second, the assessment of when a state regulatory measure becomes an expropriation will be made via a close study of arbitral awards.

(a) Scope of coverage of taking provisions in investment agreements

BITs and other international instruments for the protection of foreign investment virtually always contain provisions prohibiting the taking of assets of foreign investors by public authorities. Nevertheless, such takings are considered to be lawful if they respect four requirements namely, if done for a public purpose, on a non-discriminatory basis, with payment of compensation, and, in many cases, with due process of law.

There has often been a debate between the definition of the terms "expropriation" - taking the property of an individual firm and "nationalisation" - taking property in an industry or economy-wide context. ${ }^{337}$ The argument further advanced that expropriation is subjected to a different standard of compensation than nationalisation. IIAs traditionally do not make such a difference and a single set of rules pertain to both expropriation and nationalisation. Typical in this respect is Article 13(1) of the 1994 Energy Charter Treaty, which states:

\footnotetext{
336 Ibid.

${ }^{337}$ UNCTAD Taking of Property, above n 123, 2.
} 
Investments of Investors of a Contracting Party in the Area of any other Contracting Party shall not be nationalized, expropriated or subjected to a measure or measures having effect equivalent to nationalization or expropriation (hereinafter referred to as 'Expropriation') except where such Expropriation is...

It is traditionally acknowledged that the notion of expropriation is not restricted to scenarios where there is a official transfer of title to a property but can also include certain forms of interference by a state with property rights. IIAs reflect the concept that expropriation and nationalisation can take place in many forms which include notions such as "indirect" expropriation or action that is "tantamount" to expropriation. For example, Article III (1) of the BIT between El Salvador and the United States reads: ${ }^{338}$

Neither Party shall expropriate or nationalize a covered investment either directly or indirectly through measures tantamount to expropriation or nationalization ('expropriation') except ...

Similarly, NAFTA in Article 1110 (1) states:

No Party may directly or indirectly nationalize or expropriate an investment of an investor of another Party in its territory or take a measure tantamount to nationalization or expropriation of such an investment ('expropriation') except: ...

It has been suggested that a "direct" expropriation is characterised by acts that transfer title and physical possession, whereas "indirect" expropriation involves acts that effectuate the loss of management, use or control, or a significant depreciation in the value, of assets. ${ }^{339}$ The Free Trade Agreements between Singapore and the United States $^{340}$ and between Chile and the United States ${ }^{341}$ provide that an establishment of whether an act or series of acts comprise indirect expropriation necessitates a case-bycase inquiry. This would be done based on judging the economic impact of the measure, the extent to which the government action infringes reasonable investment-backed expectations, and the character of the government action. In addition, it is specified that

\footnotetext{
${ }^{338}$ Treaty Concerning the Encouragement and Reciprocal Protection of Investment (United States - El Salvador) (signed 10 March 1999).

${ }^{339}$ UNCTAD Taking of Property, above n 123, 3-4.

${ }^{340}$ Free Trade Agreement between The United States and Singapore (signed 6 May 2003 and entered into force 1 January 2004).

${ }^{341}$ Free Trade Agreement between The United States and Chile (signed 6 June 2003 and entered into force 1 January 2004).
} 
non-discriminatory regulatory actions are applied only in special circumstances where legitimate public welfare objectives are involved. It is not plausible to derive a definition for these terms from international tribunal arbitrations.

The broad scope of the notion of expropriation used in the IIAs (arising from the references to indirect expropriation and processes with similar effects) has raised about the question of whether compensable expropriation of foreign investment would be the result of a state exercising its regulatory powers in matters of trade, taxation, and public health. As a result, in addition to the concepts of direct and indirect expropriation, the literature often employs the concept of "regulatory takings". One suggested definition is that regulatory takings "are those takings of property that fall within the police powers of a state, or otherwise arise from measures like those pertaining to the regulation of the environment, health, morals, culture or economy of a host country." ${ }^{342}$ Nevertheless IIAs do not unequivocally use the phrase "regulatory takings"; such takings are included under the broad scope of indirect expropriation. In the context of the OECD negotiations on a MAI, a statement was adopted by OECD Ministers to the effect that "the MAI will not inhibit the exercise of the normal regulatory powers of government and that the exercise of such powers will not amount to expropriation." 343

The concept of indirect expropriation and non-compensable regulatory governmental measures as two distinct notions has not been systematically articulated. ${ }^{344}$ Nevertheless, tribunals when providing their findings in many awards have found various criteria in order to distinguish these concepts: ${ }^{345}$ "i) the degree of interference with the property right; ii) the character of governmental measures (ex: the purpose and the context of the measure); iii) the interference of the measure with reasonable and investment-backed expectations." In addition to the criteria determined via the jurisprudence whether an indirect expropriation has occurred, the state practice is also

\footnotetext{
${ }^{342}$ UNCTAD The Taking of Property, above n 123, 12.

${ }^{343}$ MAI, above n 73, Annex 2, paragraph 8.

${ }^{344}$ August Reinisch "Expropriation", above n 142, 432.

${ }^{345}$ OECD Indirect Expropriation and The Right To Regulate in International Investment Law Working Papers on International Investment Number 2004/4 (OECD, 2004) 22.
} 
significant in relation to this issue. Accordingly, recently signed FTAs establish explicitly a list of what represents an indirect expropriation: $:^{346}$

The determination of whether an action or series of actions by a Party, in a specific fact situation, constitutes an indirect expropriation requires a case-by case, fact-based inquiry that considers, among other factors:

(i) the economic impact of the government action, although the fact that an action or series of actions by a Party has an adverse effect on the economic value of an investment, standing alone, does not establish that an indirect expropriation has occurred;

(ii) the extent to which the government action interferes with distinct, reasonable investment-backed expectations; and

(iii) the character of the government action.

Furthermore, these FTAs address the borderline between indirect expropriation and the right to regulate: $:^{347}$

Except in rare circumstances, non discriminatory regulatory actions by a Party that are designed and applied to achieve legitimate public welfare objectives, such as the protection of public health, safety and the environment, do not constitute indirect expropriations.

These criteria are consistent with those emerging from arbitral decisions. Such a detailed list of criteria provides a significant assistance when determining whether an indirect expropriation requiring compensation has occurred.

The question of when a state regulation becomes an expropriation has arisen in connection with several arbitration proceedings in particular under the investment chapter of the NAFTA.

(b) Expropriation-related arbitral awards

A review of above past arbitral awards demonstrates that when challenged by a claim that a host state measures are an expropriation, tribunals have approached the issue in diverse ways.

\footnotetext{
${ }^{346}$ US-Australia Free Trade Agreement, above 259, Annex 11-B, Article 4(b); US-Chile Free Trade Agreement, above n 341, annex 10-D; US-Central America Free Trade Agreement (CAFTA) (signed 28 January 2004 between Costa Rica, El Salvador, Guatemala, Honduras and Nicaragua) Annex 10-C; USMorocco Free Trade Agreement (signed 15 June 2004) Annex 10-B. ${ }^{347}$ Ibid.
} 
- The first approach ignores the host states' need for policy space. This approach places investment protection in a position of primacy and refuses to consider the policy reasons underlying the challenged measures taken by the host state

- The second approach is prepared to be aware of the public policy aim of the challenged measure but requires a rational relationship of proportionality between the weights the measure places on the investor and the public interest aim of the measure.

- The third approach does not treat the public policy aim of the challenged measure as a criterion to be weighed against the burden on the investor, but rather a determining factor which prevents the measure being an expropriatory measure.

Hence, in its 2000 award the tribunal in Metalclad $v$ Mexico took the view that the purpose of a measure depriving an investor of the benefit of its investment is irrelevant to whether or not the measure may amount to an expropriation. ${ }^{348}$ The measures at issue in Metalclad were a decision by the municipal authority not to grant a permit to operate a hazardous waste site and a subsequent government decree declaring the site part of a nature reserve for the protection of rare cacti.

The second approach is illustrated by the case of Técnicas Medioambientales Tecmed S.A v Mexico which also concerned a permit for a hazardous waste site in Mexico. ${ }^{349}$ In that case Tecmed commenced ICSID arbitration proceedings alleging that the Mexican government's failure to re-license its hazardous waste site was an expropriation in breach of the Spain-Mexico BIT. In its analysis the tribunal stated: ${ }^{350}$

The principle that the State's exercise of its sovereign power within the framework of its police power may cause economic damage to those subject to its powers as administrator without entitling them to any compensation whatsoever is undisputable

\footnotetext{
${ }^{348}$ Metalclad Corporation v United Mexican States, above n 125, para 111.

${ }^{349}$ Técnicas Medioambientales Tecmed S.A v The United Mexican States, above n 55.

${ }^{350}$ Ibid, para 119.
} 
However, in deciding whether or not the conduct of Mexico was an expropriation requiring the investor to be compensated, the tribunal drew on jurisprudence from the European Court of Human Rights, which has held that: ${ }^{351}$

\begin{abstract}
Not only must a measure depriving a person of his property pursue, on the facts as well as in principle, a legitimate aim "in the public interest", but there must also be a reasonable relationship of proportionality between the means employed and the aim sought to be realised.... The requisite balance will not be found if the person concerned has had to bear "an individual and excessive burden" ... The Court considers that a measure must be both appropriate for achieving its aim and not disproportionate thereto.
\end{abstract}

After a lengthy analysis, the Tecmed tribunal found that Mexico's conduct did amount to an expropriation in that case.

The third approach is demonstrated by the Methanex Corporation v United States award. ${ }^{352}$ The decision is important in a number of respects, but the most significant for present purposes is its approach to the allegation of Methanex that the state of California's ban on MTBE was a measure tantamount to expropriation within Article 1110 of NAFTA. In dismissing the claim of Methanex, the tribunal held: ${ }^{353}$

\begin{abstract}
In the Tribunal's view, Methanex is correct that an intentionally discriminatory regulation against a foreign investor fulfils a key requirement for establishing expropriation. But as a matter of general international law, a non-discriminatory regulation for a public purpose, which is enacted in accordance with due process and, which affects, inter alios, a foreign investor or investment is not deemed expropriatory and compensable unless specific commitments had been given by the regulating government to the then putative foreign investor contemplating investment that the government would refrain from such regulation.
\end{abstract}

It held that the United States had made no such commitments to Methanex. The tribunal ultimately dismissed all of the claims of Methanex and ordered Methanex to pay the costs of the arbitration as well as the United States' legal costs. In its amicus curiae, the IISD suggests that one of the possible categories of expropriation included under Article 1110 of NAFTA is "the disputed notion of regulatory taking, whereby the diminution of economic value due to a regulation that protects the public interest

\footnotetext{
${ }^{351}$ In the case of James and Others (21 February 1986) ECHR (Judgment) 50-19-20, available at http://hudoc.echr.coe.int (last accessed 02 August 2009).

352 Methanex Corporation v United States, above n 69.

${ }^{353}$ Ibid, Part IV Chapter D, para 7.
} 
becomes the basis for a finding of expropriation." 354 In the Methanex case, the United States have held about this issue that: ${ }^{355}$

It is a principle of customary international law that, where economic injury results from bona fide regulation within the police powers of a State, compensation is not required... Thus, as a general matter, States are not liable to compensate aliens for economic loss incurred as a result of nondiscriminatory action to protect the public health.

The IISD stresses that welfare measures taken in good faith are outside the notion of expropriation since they are measures that clearly falls into the police powers of a state. ${ }^{356}$ Therefore, no compensation shall be rewarded. ${ }^{357}$

The approach taken by the Methanex tribunal was affirmed and elaborated upon in the 2006 award in Saluka Investments BV v Czech Republic. ${ }^{358}$ Saluka claimed that the placing of the bank in forced administration was a deprivation under article 5 of the BIT. In its 2006 award, the tribunal agreed with Saluka that the government had breached the fair and equitable treatment standard with respect to its conduct prior to the forced administration. However, it held that the forced administration did not amount to a deprivation under article 5 of the BIT. The tribunal noted that article 5 does not contain any explicit exception for the exercise of regulatory power. ${ }^{359}$ It continued: ${ }^{360}$

\begin{abstract}
However, in using the concept of deprivation, Article 5 imports into the Treaty the customary international law notion that a deprivation can be justified if it results from the exercise of regulatory actions aimed at the maintenance of public order. In interpreting a treaty, account has to be taken of "any relevant rules of international law applicable in the relations between the parties" a requirement which the International Court of Justice (ICJ) has held includes relevant rules of general customary international law.
\end{abstract}

The tribunal added: ${ }^{361}$

It is now established in international law that States are not liable to pay compensation to a foreign investor when, in the normal exercise of their regulatory powers, they adopt in a non-discriminatory manner bona fide regulations that are aimed at the general welfare.

\footnotetext{
${ }^{354}$ Methanex Corporation and United States of America, above n 102, 16.

${ }^{355}$ United States, Amended Statement of Defense of the Respondent United States of America (5 December 2003) paras 410 and 411.

${ }^{356}$ Methanex Corporation and United States of America, Amicus Curiae Submissions by the IISD, above $\mathrm{n}$ $268,17$.

357 Ibid.

${ }^{358}$ Saluka Investments BV v Czech Republic, above n 67.

${ }^{359}$ Ibid, para 254

${ }^{360}$ Ibid.

${ }^{361}$ Ibid, para 255.
} 
Although the tribunals in Methanex and Saluka clearly recognize host states' right to policy space, as noted by the Saluka tribunal: ${ }^{362}$

...international law has yet to identify in a comprehensive and definitive fashion precisely what regulations are considered "permissible" and "commonly accepted" as falling within the police or regulatory power of States and, thus, non-compensable. In other words, it has yet to draw a bright and easily distinguishable line between non-compensable regulations on the one hand and, on the other, measures that have the effect of depriving foreign investors of their investment and are thus unlawful and compensable in international law.

The Saluka tribunal held that: ${ }^{363}$

It thus inevitably falls to the adjudicator to determine whether particular conduct by a state "crosses the line that separates valid regulatory activity from expropriation. Faced with the question of when, how and at what point an otherwise valid regulation becomes, in fact and effect, an unlawful expropriation, international tribunals must consider the circumstances in which the question arises. The context within which an impugned measure is adopted and applied is critical to the determination of its validity.

Unfortunately for host states, this means that even on the most progressive of approaches, there still remains a lack of clarity over the circumstances in which a public policy measure will be considered expropriatory. This reinforces the need for clearlyworded provisions addressing this point to be included in the treaties themselves.

Section A has provided a detailed overview of how state regulations regarding tax, environment, labour and expropriation are regulated in modern investment treaties, including the underlying policy issues that are reflected in the tension between international controls, on the one hand, and state sovereignty on the other. The awards discussed above demonstrate a growing recognition of the need to allow host states their policy space. These positive signs must be read carefully however. Many tribunals continue to issue decisions without any reference to host state policy space and only a few mention it. Moreover, the lack of a doctrine of precedent means that more promising decisions may not be followed by tribunals in the future. The only way to ensure that a tribunal will take the need for policy space into account is by including express

\footnotetext{
362 Ibid, para 263.

${ }^{363}$ Ibid, para 264.
} 
provisions in the treaty itself. Further suggestions for finding ways of avoiding inconsistency in the awards rendered by arbitral tribunals need to be analysed.

\section{B The Right to Regulate in International Investment Agreements}

From this discussion of the interaction of state policies with substantive investment obligations, a central question arises: how could host states amend the existing language of treaties in order to avoid a conflict between their ability to implement regulatory measures in the public interest and their duty not to breach the rights of investors in the future? In this section, some solutions will be suggested. A new treaty language appears necessary in the light of the challenge that arbitral tribunals face regarding the consistency of their awards.

\section{$1 \quad$ Alternative formulations for a new treaty language}

A new definition of the right to regulate in IIAs seems to be required when addressing the issue of the public welfare legislation of host states. In this light, UNCTAD has listed three main approaches which have emerged from the IIA negotiating practice of a small but growing number of countries: ${ }^{364}$

(a) Some countries have clarified individual IIA provisions, where there was concern that an expansive interpretation could diminish regulatory flexibility of host countries. This has happened with regard to provisions guaranteeing fair and equitable treatment of investment and the definition of an indirect expropriation.

(b) Numerous recent IIAs include stronger emphasis on public policy concerns in order to ensure that investment protection is not pursued at the expense of other legitimate public interests. For example, they include exceptions for host country measures to maintain national security, preserve the public order or to protect public health, safety or the environment. Exceptions have been met with the concern that they may undermine the purpose of the IIA by providing the host country with a potentially broad justification for derogating from IIAs obligations. In addition, such provisions have been the subject of a few arbitral awards and thus their scope is not yet widely understood. Other IIAs include provisions calling upon host countries not to depart from labour or environmental standards in attracting foreign investment, though often these provisions impose no binding obligation.

${ }^{364}$ UNCTAD Development Implications of International Investment Agreements (UNCTAD, IIA Monitor No. 2, 2007) 6 . 
(c) A few IIAs have strengthened the public's role in investor-State dispute resolution by providing for greater transparency in proceedings, open hearings, publication of related legal documents, and allowing civil society representatives to submit amicus curiae briefs to tribunals.

(a) The use of the preamble clauses

A widespread characteristic of arbitration decisions under IIAs is reference to the preamble and objective clauses of such agreements. ${ }^{365}$ These are used, consistent with the general rules on treaty interpretation under international law, as an interpretive aid for the substantive provision of the treaty. ${ }^{366}$

To date the preamble and objectives of IIAs have focused on the protection of the investor as the basis for attracting higher levels of investment. ${ }^{367}$ Hardly any actually contain references to such matters as protection of the environment, sustainable development, protection of human health or the need for recognition of the right or duty of states to regulate, for example. ${ }^{368}$ Hence, most arbitral decisions have focused on the object and purpose of protecting the investor as the principle interpretive guide to to the substantive provisions of the IIA. ${ }^{369}$

Nevertheless, this is not always the case. A growing number of IIAs include references to issues beyond the protection of the investors. In this light, the Preamble of NAFTA reads: ${ }^{370}$

The Government of Canada, the Government of the United Mexican States and the Government of the United States of America, resolved to:

$[\ldots]$

CREATE new employment opportunities and improve working conditions and living standards in their respective territories;

UNDERTAKE each of the preceding in a manner consistent with environmental protection and conservation;

PRESERVE their flexibility to safeguard the public welfare;

PROMOTE sustainable development:

\footnotetext{
${ }^{365}$ Howard Mann Investment Agreements and the Regulatory State: Can Exceptions Clauses Create a Safe Haven for Governments?, above n 10, 7.

${ }^{366}$ Ibid, 7.

${ }^{367}$ Ibid, 7.

${ }^{368}$ Ibid, 7.

${ }^{369}$ M Sornarajah The International Law on Foreign Investment, above n 116, 217.

${ }^{370}$ NAFTA, above n 17, Preamble. See also ECT, above n 18, Preamble.
} 
STRENGTHEN the development and enforcement of environmental laws and regulations; and PROTECT, enhance and enforce basic workers' rights.

This example emphasises the fact that there are alternatives available for negotiators to move beyond the previous restricted statements of entirely economic objectives, whether in a preamble or in an objectives clause, to summarise the relationship of investments to the host state in a broader way. ${ }^{371}$ When these concerns are dealt with in the preamble or an objectives clause, it enhances the probability that a tribunal called upon to construe the substantive clauses will take a more unprejudiced view of them. ${ }^{372}$ If the regulatory rights of states are expressly recognised in a preamble or objectives clause, it can also improve the chances that the police powers rule, even if not expressly referred to in the clause, will be cited as an interpretational guide to any provision on expropriation. ${ }^{373}$

(b) The inclusion of regulatory measures articles

Another option is to include in the substantive provisions of an IIA specific references to the regulatory rights or duties of states. ${ }^{374}$ Whilst still not frequent there are at least a handful of examples of this. ${ }^{375}$

When included in the substantive section of a treaty it is possible for such articles to have a considerable impact on a tribunal's elucidation of a treaty. ${ }^{376}$ It is a fundamental concept in treaty interpretation that each clause must be interpreted in the context of the other provisions in the treaty. ${ }^{377}$ The express recognition of a state's right to regulate investments will have to be taken into account when interpreting the other substantive provisions. $^{378}$

\footnotetext{
${ }^{371}$ Ibid, 7.

372 Ibid, 7.

${ }^{373}$ Ibid, 7.

${ }^{374}$ Ibid, 7.

375 Aaron Cosbey, Howard Mann, Luke Eric Peterson and Konrad Von Moltke Model International Agreement on Investment for Sustainable Development Article 25.

${ }^{376}$ Howard Mann Investment Agreements and the Regulatory State: Can Exceptions Clauses Create a Safe Haven for Governments?, above n 10, 8.

${ }^{377}$ Ibid, 8.

${ }^{378}$ Ibid, 8.
} 
Possibly the most general example of such an approach is found in the Energy Charter Treaty (ECT) which includes the conventional investor protection provisions found in all IIAs and also includes two special provisions relating to regulation, one on the sovereign right to regulate in general ${ }^{379}$ and one more precisely to the environment: ${ }^{380}$ this emphasises the necessity of recognising the prospect of future regulation in the context of an IIA.

It is critical to be conscious of the so-called regulatory exception clauses, which can be misleading. Article 1114 of NAFTA, titled Environmental Measures states:

\footnotetext{
Nothing in this Chapter shall be construed to prevent a Party from adopting, maintaining or enforcing any measure otherwise consistent with this Chapter that it considers appropriate to ensure that investment activity in its territory is undertaken in a manner sensitive to environmental concerns.
}

The issue with this article is that it has no legal implications, even though it appears to generate a broad exclusion for environmental law measures distinctively. ${ }^{381}$ It does nothing to protect a government against a claim that a measure is a breach of the Chapter. None of NAFTA's three parties have accorded the provision much weight. ${ }^{382}$

One may note that there is a principal focus on environmental regulatory issues in many of the case studies we have looked at before. ${ }^{383}$ Without a doubt, this is a reflection of very outspoken interests of environmental NGOs in the 1990s, when the issues first came to public attention. ${ }^{384}$ In recent times partnership between countries has been more specifically focused on investment agreements, unlike before when there were certain restrictions put on developing countries (preventing imposition of environmental standards). ${ }^{385}$ The importance of guaranteeing developing nations policy space, however, is not limited to environmental measures but also concerns other public welfare issues. ${ }^{386}$

\footnotetext{
${ }^{379}$ ECT, above n 18, Article 18.

${ }^{380}$ Ibid, Article 19.

${ }^{381}$ Howard Mann Investment Agreements and the Regulatory State: Can Exceptions Clauses Create a Safe Haven for Governments?, above n 10, 8 .

382 Ibid, 8 .

${ }^{383}$ Ibid, 8 .

${ }^{384}$ Ibid, 8 .

385 Ibid, 8 .

${ }^{386}$ Ibid, 9 .
} 
(c) General exclusions

General exclusions may be found in three types of annexes in various investment treaties, namely the exclusion of specific sectors from some or all of the obligations of the IIA, ${ }^{387}$ the exclusion of measures from the obligations of the IIA, ${ }^{388}$ and finally the exclusion of future measures from the obligations of the IIA. ${ }^{389}$

The probability of such exclusions is based on the level of broadly-based exclusions; this may include issues that can lead to claims of expropriation or other obligations. Nevertheless it should be noted that such an approach must not be misused as a means of circumventing obligations under an agreement.

Many agreements include precise provisions excluding certain types of measures, like taxation measures. ${ }^{390}$ There are multiple examples of this, such as the Colombia Model BIT, Article II.4: "The provisions of this Agreement shall not apply to tax matters." The possibility to include provisions in a text that also excludes other types of government measures can be looked at with the use of the above example. ${ }^{391}$ Specific exclusions like that of environmental protection measures excluded from indirect expropriation are not prevalent except for taxation measures but are a definite possibility. $^{392}$

It is noteworthy that among the BITs concluded in the last decade, general exception clauses are more often included. The rationale for a general exception is to exempt a contracting party from the obligations of the BIT in situations in which compliance would be incompatible with key policy objectives explicitly identified in the agreement. The exceptions cover a wide variety of policy objectives, including taxation, essential security and public order, protection of human health and the environment, and more. The more frequent use of exception clauses reflects a tendency to give more weight to certain public policy concerns in connection with BITs. Most often, for a general exception to be permitted, the otherwise inconsistent measure by the contracting party

\footnotetext{
${ }^{387}$ For example, see the Argentine Republic-New Zealand BIT, above n, Article 5 (2).

${ }^{388}$ For example, see the NAFTA, Article 1106 (6).

${ }^{389}$ For example, see the United States-Australia Free Trade Agreement, above n, Article 19.8.

$390{ }^{390}$ Howard Mann Investment Agreements and the Regulatory State: Can Exceptions Clauses Create a Safe Haven for Governments?, above n 10, 11.

${ }^{391}$ Ibid, 11.

392 Ibid, 11 .
} 
must be applied on a non-discriminatory basis. Therefore, general exceptions ensure that the BIT obligations do not prevent the country concerned from applying its domestic legislation in order to safeguard any of these fundamental values. Another approach taken in some BITs is to emphasise that investment promotion and protection must not be pursued at the expense of other key policy objectives, particularly in the area of public health and safety, environmental protection and respect of core labour rights.

However, these provisions suffer from a certain normative weakness insofar as they do not clearly identify to what extent the protection of investments is limited for the sake of legitimate public policy. Thus, the interpretative clause mentioned above will legitimise environmental policies which are "in addition in conformity with the present agreement". Consequently, this clause loses all of its strength since it is considered only once the court has determined that a measure of the host state did not violate the rights of the investor. In addition, the concerned clauses limit their field of application to certain public policies. This could be interpreted $a$ contrario as providing a way to restrict the others in the name of the protection of investments.

A complex form of exclusion clause seen in the use of general exception clause is modelled on Article XX of the GATT. ${ }^{393}$ An example of such a clause is found in Article 13 of the ASEAN Framework Agreement on Investment:

\footnotetext{
Subject to the requirement that such measures are not applied in a manner which would constitute a means of arbitrary or unjustifiable discrimination between countries where like conditions prevail, or a disguised restriction on investment flows, nothing in this Agreement shall be construed to prevent the adoption or enforcement by any Member State of measures; (a) necessary to protect national security and public morals; (b) necessary to protect human, animal or plant life or health; (...)
}

The essence of the text is unclear as it raises issues of discrimination between countries where similar conditions exist. ${ }^{394}$ Such a provision would predominantly be for measures ratified by a single government within its own borders and has no connection to the conditions in other countries. ${ }^{395}$

\footnotetext{
${ }^{393}$ Ibid, 11.

${ }^{394}$ Ibid, 11.

${ }^{395}$ Ibid, 11 .
} 


\section{(d) Clarity of key standards}

It is critical to note that there is an increasing need for IIAs to be clear. ${ }^{396}$ Various BITs which have been signed in the past are examples of growing complexity of IIAs; more recently there have been many agreements between developed and developing nations. $^{397}$

Arguments based on the standards of fair and equitable treatment, national treatment and most-favoured nation treatment have arisen as a result of the implications of trade law. In many cases, investors have argued that a comparison of foreign and domestic investors has shown that many of their interests have not been served, though they seem to be treated the same way as other investors. ${ }^{398}$ This gives rise to argument from investors against states' measures based on many factors such as geographical location, environmental impacts, and human health and so on. ${ }^{399}$

\section{Promotion of consistency in investment arbitration}

Is there consistency of results in arbitration today and how can consistency be improved $?^{400}$

A few solutions are treaty or fact-based. It must be recognised that there are intrinsic inconsistencies in any legal system. Questions of whether similar answers are being given to similar questions arise all the time, which provokes one to reflect on the relationship between law and application of following precedents. ${ }^{401}$ Legal theory claims that we have the obligation to strive towards consistency and predictability because of the notion that the rule of law requires law to be consistently applied by following precedents. $^{402}$

\footnotetext{
396 Ibid, 12

${ }^{397}$ Ibid, 12.

${ }^{398}$ Ibid, 12

${ }^{399}$ Ibid, 12

${ }^{400}$ Gabrielle Kaufmann-Kohler Is Consistency a Myth in Emmanuel Gaillard and Yas Banifatemi (eds) "Precedent in International Arbitration" (Juris Publishing, 2008) 138.

${ }^{401}$ Ibid, 143.

402 Ibid.
} 
This obligation is not consistent in all fields of law. ${ }^{403}$ The less developed a legal system is, the greater the importance of whoever must resolve disputes. Investment law is in its early stages and definitely calls for greater level of consistency, although no doctrine of precedent exists as such in investment arbitration. ${ }^{404}$

From the above, it is clear that the use of precedents is the best route by which investment law is to achieve consistency. For such precedents to promote consistency, tribunals would have to methodically base themselves on a consistent line of cases and shift only for compelling reasons. ${ }^{405}$ As time goes by, this practice could evolve into a rule of customary international law. ${ }^{406}$

\section{Interim Conclusion}

Drafting a provision that adequately addresses the issues of the protection of the foreign investor, and the ability of the host state to govern its economy can pose a challenge. Although some IIAs have sought to list the regulatory measures the exercise of which will not amount to taking, the compilation of an exhaustive list is a difficult, if not impossible, task. Instead, takings clauses as well as tax, environmental and labour provisions could be drafted to reflect the formulation of a certain relationship that can accommodate both the concerns of foreign investors and national policy makers. The various policy options expressed above require the need to strike a balance between the level of investment protection, on the one hand, and the level of discretion retained by the host state in adopting measures that affect foreign investments, on the other hand. However, with respect to the question of countries balancing the immediate economic impact sought from FDI, and core national welfare measures, some controversy might exist. In order to deal with this debate, the following questions need to be answered during negotiations of the parties of a new investment treaty:

- To what extent could IIAs in general contribute to public welfare in the light of specialised instruments dealing with the different public policies analysed above?

\footnotetext{
${ }^{403}$ Ibid, 144.

${ }^{404}$ Ibid, 145.

405 Ibid, 146.

${ }^{406}$ Ibid, 147.
} 
- Where IIAs address these concerns, should standards be included?

- If so, how are these standards defined, to who are they addressed, and should they be binding or non-binding?

- How will they interact with standards contained in specialised instruments on the same matters?

The discussion of these questions will also require a balancing of at least two sets of arguments. First, the prescription of certain standards in some circumstances amounts to a form of disguised protectionism. Secondly, that the need to promote certain tax, environmental, employment, and privatisation standards may outweigh certain negative impacts on trade or investment growth.

The extension of the imposition of certain national regulatory measures that could constitute compensable expropriation has been well-addressed by Thomas Wälde and Abba Kolo. The authors stated: ${ }^{407}$

The investment rules will therefore have to impact on the way the broad environmental principles are interpreted and applied, and the environmental principles will play a role in legitimizing regulation subject to the scrutiny of the investment protection rules. Both set of rules, conceptual approaches and values ... have to merge under the sign of mutual respect.

Such an explanation could be extended to all regulatory public measures taken by the host state. In this light, a need for a practice of partnership between the host state and the investor arises.

\footnotetext{
407 Thomas Wälde and Abba Kolo "Environmental Regulation, Investment Protection and Regulatory Taking in International Law” 50 ICLQ 811, 819.
} 


\section{CHAPTER IVLOGIC OF SOVEREIGNTY TO A PARTNERSHIP BETWEEN HOST STATES AND FOREIGN INVESTORS}

Host states have different options to resolve the tension between international security of investments and the public policies constrained by this security. Host states can choose to respond to the challenge with a sovereign mindset: as a "power-state" acting in a unilateral manner towards private persons, including foreign investors, and only consulting with other states. This sovereign approach would consist either of following public policies while violating, if the need arises, commitments made under international investment law or trying to change amend international investment law by agreement with other contracting states. The first approach ought to be dismissed as it is less likely to take place given the interest of states in attracting investments. The idea of amending international investment law, however, deserves to be explored.

The host state can also advocate certain alternative methods of public partnership, adopting a cooperation perspective towards investors. In this light, several policy tools will be under focus. The precise measure must without a doubt be defined on a case by case basis, but the idea of cooperation is promising. Finally, the author suggests that the best way to ensure a balanced state-investor partnership is perhaps via including a general provision in the preamble of every IIA which considers the right to a security of international investment without threatening host states regulatory power.

\section{A The Natural Sovereign Temptation: Reduction of the Security of Investment Agreements}

Adopting a sovereign mindset, a host state might require the renegotiation of existing security agreements, and change its requirements for future agreements of this kind. A host state might want to rule out state-investor arbitration, reduce the scope of protective provisions or make provision for a general exception. None of these options are satisfying.

$1 \quad$ Rejection of arbitration: an inappropriate response 
(a) The withdrawal of Ecuador from ICSID

The role of ICSID can be explained by means of case studies, especially from Latin America. In the early 1990s, President Sixtó Durán Ballén implemented a series of measures which helped Ecuador open its doors to Foreign Trade and Capital. Many significant developments followed, including the admission of Ecuador to the World Trade Organisation, the signature of various BITs and, most importantly, an increase in FDI, tripling in the two years between 1992 and 1994; the FDI further doubled between 1996 and $1998 .^{408}$ This trend became unstable after his presidency. ${ }^{409}$ The instability of FDI in the country grew after the currency (the sucre) was demonetised in the late 1990s. ${ }^{410}$

By 2006 Rafael Correa assumed office as the new President of Ecuador. By this time Ecuador was concluding its negotiations on a free trade agreement with the United States. ${ }^{411}$ This process stalled, however, because of the new hydrocarbons law requiring the revision of contract terms. ${ }^{412}$ This was followed by the seizure of assets from Occidental Petroleum who was at this time the largest investor in Ecuador. ${ }^{413}$ The acts of the Correa administration led to one of the largest claims ever filed before the ICSID. ${ }^{414}$

Correa's administration announced a decision to impose new taxes on foreign oil companies, by ordering them to pay $99 \%$ of their income to the government. ${ }^{415}$ As a result of this in the first half of 2008 almost six major oil companies filed claims against Ecuador at the ICSID. ${ }^{416}$

On 4 December 2007, Ecuador informed ICSID formally that it would not give consent to ICSID in matters relating to the treatment of investments in economic

\footnotetext{
${ }^{408}$ Ignacio Vincentelli "The Uncertain Future of ICSID in Latin America" (Independent Research Paper) (University of Miami School of Law, 2008) 44.

${ }^{409}$ Ibid.

${ }^{410}$ Ibid.

${ }^{411}$ Ibid, 45 .

${ }^{412}$ Ibid.

${ }^{413}$ Ibid.

${ }^{414}$ Ibid.

${ }^{415}$ Ibid.

${ }^{416}$ Ibid.
} 
activities that concern the exploitation of natural resources of the country. ${ }^{417}$ Such a notification was based on Article 25(4) of the Washington Convention which states:

\begin{abstract}
Any contracting state may, at the time of ratification, acceptance or approval of this convention or at any time thereafter, notify the centre of the class or classes of disputes which it would or would not consider submitting to the jurisdiction of the Centre. The Secretary-General shall forthwith transmit such notification to all contracting states. Such notification shall not constitute the consent required by paragraph (1).
\end{abstract}

The withdrawal of Ecuador from the ICSID constrains the scope of the jurisdiction of the Centre. An example of such a case is Československa Obchodni Banka, a.s. v The Slovak Republic. ${ }^{418}$ If a contracting state wishes to exclude a particular investment from the reach of the Convention, Article 25(4) provides a more appropriate way to do so rather than defying the meaning of the term "investment" under the Convention. ${ }^{419}$ The tribunal articulated that the acceptance of such jurisdiction with respect to the terms and obligations arising out of their agreement creates a strong presumption that they deemed their transaction to be an investment within the meaning of the ICSID Convention. ${ }^{420}$

Furthermore, the arbitral tribunal stated that: ${ }^{421}$

\begin{abstract}
It is worth noting, in this connection, that a Contracting State that wishes to limit the scope of the Centre's jurisdiction can do so by making the declaration provided for in Article 25(4) of the Convention. The Slovak Republic has not made such a declaration and has, therefore, submitted itself broadly to the full scope of the subject matter jurisdiction governed by the Convention.
\end{abstract}

Applying the reasoning of the tribunal to Ecuador, after the notification on the 4 December 2007, the country has limited the scope of the jurisdiction of the Centre in disputes. ${ }^{422}$ By restraining the scope of the ICSID jurisdiction in disputes arising out of

\footnotetext{
417 Ibid, 46.

${ }^{418}$ Československa Obchodni Banka, a.s. v The Slovak Republic (Decision on Objections to Jurisdiction) (1999) 14 ICSID Rev.

${ }^{419}$ Ignacio Vincentelli “The Uncertain Future of ICSID in Latin America”, above n 408, 47.

${ }^{420}$ Ibid.

${ }^{421}$ Československa Obchodni Banka, a.s. v The Slovak Republic, above n 418, para 65.

${ }^{422}$ Ignacio Vincentelli “The Uncertain Future of ICSID in Latin America”, above n 408, 47.
} 
natural resource investments, including oil, and gas, and other minerals, Ecuador might no longer be taken to arbitration in these types of cases. ${ }^{423}$

An important legal issue in the context of exclusion from the ICSID is whether it can be used on an ex post facto basis. ${ }^{424}$ This issue is addressed in Alcoa Minerals Jamaica $v$ Jamaica ${ }^{425}$ In 1968 Alcoa Minerals entered into an investment contract with Jamaica for the construction of a refining plant, in exchange for a series of tax concessions including a 'no-further-tax' provision, and a right to long term bauxite mining. ${ }^{426}$ This agreement included an important ICSID arbitration provision. ${ }^{427}$ In 1974, the Jamaican government announced a unilateral increase in the tax on mining bauxite. ${ }^{428}$ Since the parties could not reach an agreement on this development, the government imposed a new tax by enacting the Bauxite Act which dramatically increased the tax on mining of bauxite. ${ }^{429}$ However, prior to the enactment of Bauxite Act, the Jamaican government notified the Centre in accordance with Article 25(4) of the exclusion of disputes arising from investments and related to natural resources. ${ }^{430}$ For this reason, when Alcoa decided to bring a claim against Jamaica before ICSID, Jamaica, relying on Article 25(4), did not appear before the ICSID Tribunal. ${ }^{431}$ However, the Tribunal found jurisdiction by deciding the issue of whether the notification of Jamaica had the effect of withdrawing natural resources investment disputes from the scope of Jamaica's prior consent to arbitrate. ${ }^{432}$

The tribunal ruling on the authority to arbitrate in this case is critical today. ${ }^{433}$ The tribunal held that the agreement of the parties to an ICSID arbitration provision fulfilled the condition of consent required by Article 25(1), which may not be withdrawn thereafter. ${ }^{434}$ A decision finding otherwise "would very largely, if not wholly, deprive the

${ }^{423}$ Ibid.

${ }^{424}$ Ibid, 48

${ }^{425}$ Alcoa Minerals Jamaica v Jamaica (Decision on Jurisdiction) (1975) 4 Y B Com Arb, 206 and 208.

${ }^{426}$ Ignacio Vincentelli "The Uncertain Future of ICSID in Latin America”, above n 408, 48.

${ }^{427}$ Ibid, 49 .

${ }^{428}$ Ibid.

${ }^{429}$ Ibid.

${ }^{430}$ Ibid.

${ }^{431}$ Ibid.

432 Ibid.

${ }^{433}$ Ibid.

${ }^{434}$ Ibid. 
Convention of any practical value." ${ }^{435}$ The Alcoa decision shows the success of the ICSID Convention in dealing with such problems is a guarantee to the many investors presently dependent on ICSID arbitration provisions. ${ }^{436}$

The jurisdictional outcome of such cases is extremely important for the Ecuadorian economy, as well as ICSID arbitration. ${ }^{437}$ If the ICSID tribunals find jurisdiction in these cases, Ecuador may be facing an economic crisis. ${ }^{438}$ These eventual decisions, as happened with the Alcoa case in the 1970s, may enhance and secure the reliable performance of investment agreements by showing that foreign investment need not be subject to national impulse which bodes well for ICSID in the near future. ${ }^{439}$

(b) The effect of investment protection provisions in FTAs

The Free Trade Agreement between the United States and Australia, ${ }^{440}$ which also contains a chapter about investment was the first FTA concluded since the entry into effect of NAFTA. ${ }^{441}$ This agreement does not include a provision for arbitration between the investor and the host state. ${ }^{442}$ Rather than including a direct investor-state arbitration provision, Article 11.16(1) of the United States-Australia FTA provides that the parties can enter into consultations "with a view towards allowing an investor of a party to submit a dispute to arbitration". ${ }^{443}$ Australia contended that its domestic legal system was sufficiently capable of dealing with private sector claims. ${ }^{444}$ Yet, subsequent FTAs and

\footnotetext{
${ }^{435}$ Alcoa Minerals Jamaica v Jamaica, above n 425, para II.

${ }^{436}$ Ignacio Vincentelli "The Uncertain Future of ICSID in Latin America", above n 408 Gabrielle Kaufmann-Kohler Is Consistency a Myth in Emmanuel Gaillard and Yas Banifatemi (eds) "Precedent in International Arbitration" above n 400, 49.

${ }^{437}$ Ibid, 50.

${ }^{438}$ Ibid, 51.

439 Ibid.

${ }^{440}$ Free Trade agreement between The United States of America and Australia (AUSFTA) above n 259.

${ }^{441}$ N Rubins "L'affaire Loewen c. Etats-Unis : Les Pays Exportateurs de Capital comme Défenseurs dans l'Arbitrage International" in ENA Nouveaux développements dans le contentieux arbitral transnational relatif à l'investissement international (ENA Actes du colloque, Pedone, Paris, 2004) 71.

${ }^{442}$ Australia-U.S. FTA Sets Precedent with Lack of Investor-State Dispute Mechanism Investment Law and Policy Weekly News Bulletin, 16 February 2004.

${ }^{443}$ Gilbert Gagné and Jean-Frédéric Morin "The Evolving American Policy on Investment Protection: Evidence From Recent FTAs and the 2004 Model BIT” (2006) 9(2) JIEL 357, 372.

${ }^{444}$ Ibid. 372
} 
BITs signed by the United States retain provision for direct investor-state procedures. ${ }^{445}$ Consequently, the United States exceptionally accept the lack of direct investor-state procedures in FTAs. ${ }^{446}$ This view might be justified when the FTA is signed with a developed country and which has according to some authors "a legal system developed enough to comfort US investors."

It might be argued that this approach has the advantage of freeing the state from unwanted international investment jurisprudence. There are more convincing arguments to the contrary, however. Legally, the elimination of the state-investor arbitration provision does not change the obligations of the host state on the substance. It only eliminates a particular aspect of dispute settlement. In the absence of state-investor arbitration, other settlement methods will be required, possibly including inter-state resolution via diplomatic protection. In that case, the home state of the investor defends its national by asserting its own right to internationally lawful treatment of its nationals. The dispute then becomes inter-state. Nothing prevents the state of origin of the investor from taking the side of its citizen, since he does not enjoy any recourse under his name. Consequently, there would be an unwelcome re-politicisation of international investment disputes, while the depoliticisation of investment arbitrations is precisely one of the advantages of the arbitration procedure between state and foreign investor. ${ }^{448}$

Lastly, owing to the principle of reciprocity inherent in investment treaties, developed states which choose to give up state-investor arbitration (a decision based upon belief in a domestic justice system which is supposed to be efficient) will realise that their own citizens hoping to invest abroad will from now on face a difficult situation in terms of protection. Nationals of a developed state could not use arbitration against the host (developing) state and would have to assert their rights against the host state in the context of an inadequate judicial system. It would result in a loss of international competitiveness of investors from concerned states since insurance for political risks for

\footnotetext{
${ }^{445}$ Dominican Republic-Central America-United States Free Trade Agreement (CAFTA) (5 August 2004); Treaty Between the United States of America and the Republic of Uruguay Concerning the Encouragement and Reciprocal Protection of Investment (25 October 2004).

${ }^{446}$ Gilbert Gagné and Jean-Frédéric Morin "The Evolving American Policy on Investment Protection: Evidence From Recent FTAs and the 2004 Model BIT” above n 445 , 373.

447 Ibid.

${ }^{448}$ See on this point D Small Réglement des Différends entre Investisseurs et Etats d'accueil dans un Accord Multilatéral sur l'Investissement (Pedone, Paris, 1999) 79-84.
} 
their investment activity abroad will not be granted absent an international arbitration mechanism, or only on strongly disadvantageous terms.

\section{The mistake of trying to narrow the scope of fundamental provisions}

The state which lowers the content and the scope of provisions contained in the investment agreement will face significant obstacles. ${ }^{449}$ On one hand, the host state alone would not proceed with this decrease: the state requires the agreement of the other Parties to the convention. Yet, it is uncertain that the other Party has the same interests in this respect.

In addition, even if a host state succeeds in negotiating an investment treaty with decreased protection for investments, most-favoured nation clauses still require the state to extend under each treaty any more favourable provisions included in other investment agreements negotiated by the host state. Every BIT of a state should be amended in order to avoid such a phenomenon - it seems to be a practical challenge, to say the least. Even if the conventions are negotiated by experts that generally come from various departments of economy and with all the professionalism and performance that it implies, the ratification procedure of a bilateral convention from one part and another has, as a consequence, that these texts do not come into force until a year after the end of negotiations. When states are faced with competitive situations, they have a propensity to attract investments but it might be at the cost of reducing the level of protection guaranteed in their agreements. The solution does not seem to be particularly practical in the absence of a multilateral agreement of investment. The only effect of a decrease of the level of security would be to worry potential investors as well as their insurance company.

3 The inappropriate suggestion of a general exception provision

Another solution theoretically conceivable to eliminate the dilemma between the international security of investments and public policies, but likely to cause damage to investors, is a part of substantive law. This solution would consist of including a general

\footnotetext{
${ }^{449}$ See for example the model of convention of the United States of 2004 in direct comparison with the French model which is from now on more protective of the investor.
} 
exception clause in international instruments. Such a provision would act as an exception from the obligation of the host state to offer to the investment the level of protection in theory guaranteed. Therefore, general exceptions for public policy measures would not constitute a breach of the BIT. In this respect, the United States Model BIT of 2004 makes clear what measures would not cause a breach: ${ }^{450}$ "Except in rare circumstances, nondiscriminatory regulatory actions by a Party that are designed and applied to protect legitimate public welfare objectives, such as public health, safety and the environment do not constitute indirect expropriations."

The authors of future treaties of protection of the investments could be tempted, in this respect, to draw their inspiration from the existing international law. Indeed, Article $\mathrm{XX}$ of the GATT is the general exceptions article that provides possibilities to impose trade-restrictive measures for internationally recognised, important policy objectives. GATT Article $\mathrm{XX}(\mathrm{g})$ deals with the general exception of measures "relating to the conservation of exhaustible natural resources" and Article XX(b) provides a general exception for measures "necessary to protect human, animal or plant life or health". ${ }^{451}$ GATT Article XX also applies to other functional agreements concluded within the WTO (TRIPS, TRIMS, and SPS). The GATT has its own exception provision (Article XIV). The WTO system is therefore covered by this possibility of derogation.

\footnotetext{
${ }^{450}$ United States 2004 Model BIT, above n 326, Annex B.

${ }^{451}$ Article XX General Agreement on Tariffs and Trade (GATT). See generally Bradly J Condon "GATT Article XX and Proximity of Interests: Determining the Subject Matter of Paragraphs b and g" (2005) 10 UCLA Journal of International Law and Foreign Affairs. Under GATT (1948-94), there were six disputes involving environmental measures or human health-related measures under GATT Article XX. Of the six panel reports that resulted, three were not adopted. See GATT Dispute Panel Report on U.S. Prohibition of Imports of Tuna and Tuna Products from Canada, 22 February 1982 (adopted); GATT Dispute Panel Report on Canada Measures Affecting Exports of Unprocessed Herring and Salmon, 22 March 1988, GATT B.I.S.D. (35 ${ }^{\text {th }}$ Supp) at 98 (1988) (adopted); GATT Dispute Panel Report on Thailand Restrictions on Importation of and Internal Taxes on Cigarettes, 7 November 1990, GATT B.I.S.D. (37th Supp) at 200 (1990) (adopted); GATT Dispute Panel Report on U.S. Restrictions on Imports of Tuna, 3 September 1991, GATT B.I.S.D. (39th Supp) at 155 (1991) (not adopted), 30 I.L.M. 1594 (1991); GATT Dispute Panel Report on U.S. Restrictions on Imports of Tuna, 16 June 1994 (not adopted), 33 I.L.M. 839 (1994); GATT Dispute Panel Report on U.S. Taxes on Automobiles (1994), (not adopted), 33 I.L.M. 1399 (1994). Under the WTO (since 1995), there have been three such disputes. In all three, the panel reports were appealed to the Appellate Body, whose rulings were adopted. See U.S. - Standards for Reformulated and Conventional Gasoline, WT/DS2/AB/R (1996) (Appellate Body); U.S. - Import Prohibition of Certain Shrimp and Shrimp Products, WT/DS/AB/R (1998) (Appellate Body) and U.S - Import Prohibition of Certain Shrimp and Shrimp Products, Recourse to Article 21.5 by Malaysia, WT/DS58/AB/RW (2001) (Appellate Body); and European Communities - Measures Affecting Asbestos and Asbestos -Containing Products, WT/DS135/AB/R (2001) (Appellate Body).
} 
Such a provision has already been transposed to international investment law especially at the regional level. In fact, several free trade agreements enclose sections on general exceptions. As a rule, parties opt to copy the general exception articles verbatim into their FTAs or simply incorporate Article XX GATT in their goods regime and Article XIV GATS in their services regime. This approach is translated into reality in the Australia-United States FTA, ${ }^{452}$ the NAFTA, ${ }^{453}$ the Chile-European Free Trade Association FTA (Chile-EFTA FTA) ${ }^{454}$ and the very recent New Zealand-China FTA ${ }^{455}$ to cite only a few. One can assume that this kind of provision would indeed allow host states to persist in the good management of their domestic affairs, to answer in a controlled way to environmental demands and social protection while still maintaining the international security of investments.

However, it is rare for IIAs to include provisions with a same wording. It might result in an inconsistent interpretation made by tribunals in regulatory matters. In addition, international investment law is fundamentally different to the law of the WTO: it is a prescriptive system protecting private persons, whereas the WTO deals with interstate relationships. While it is possible to make states that bear prejudicial economic consequences of their respective general interest policies, this logic does not correspond well to the asymmetrical context of international investment law as set out in the WTO. Therefore, a general exception provision would have two disadvantages in this particular context. First of all it could have perverse consequences. Indeed, the provision would lead to the financing of local public policies by foreign investors subjected to the implementation of the provision. Indeed, the value of the investment would immediately be dependent of every exception to the standard protection under the treaty. Such a forced private financing of policies is only recognised as legitimate if it undertaken through the tax system. The main domestic systems of law indeed reject every attempt of the state to take its private goods and assets without compensation, even for the most legitimate ends. That logic must continue to apply as well to the international context. Second of all,

\footnotetext{
${ }^{452}$ Free Trade agreement between The United States of America and Australia (AUSFTA), above n 259, Article 22.1.

${ }^{453}$ NAFTA, above n 17, Article 2101.

${ }^{454}$ Chile-European Free Trade Association FTA (Chile-EFTA FTA) (signed 26 June 2003 and entered into force 1 December 2004) Article 21 and Article 44.

${ }^{455}$ Free Trade Agreement between The Government of New Zealand and The Government of the People's Republic of China (NZ-China FTA), above n 332, Article 200.
} 
including a general exception provision might be creating a counterproductive incentive. Influenced by their domestic political opinion, host states would be tempted to invoke the exception provision on a frequent and exaggerated basis. Any such tendency would obviously be supervised by arbitral jurisprudence but the state has de facto a "preliminary privilege" particularly extended in international investment law.

\section{B The Need for a Partnership in International Investments}

Significant efforts expended by states to defend their cause before international arbitral authorities (unlike the 1970s and the beginning of the 1980s, where the states, respondents in a good number of arbitrations in relation to nationalisations taking place at this time, refused to participate in arbitral procedures). Host states today participate prominently at this level and hire prominent experts. The cost of receiving advice from such experts is in contrast with an excessive administrative strictness at the hands of foreign investors at the starting dispute. This measure is therefore very costly because it involves procedural costs and in some cases may entail payment of interest. In addition, such a strategy puts into peril the good business relationships between the foreign investor and the host state and its authorities. It might encourage the tribunal to make a more extreme award. As a consequence, international investment law may have a particularly disruptive effect on the state; it is often these same states willing to challenge the legitimacy of this normative system from an interstate point of view.

In order to solve these difficulties, possible decisions that might clash with investors' interests should therefore be analysed and taken in conformity with procedural guidelines established by the state itself. These procedural guidelines must, in turn, take into account the particularity of the relationships. Effectively, the foreign investor is no longer subject to the authorities of the host state according to the traditional administrative law meaning. It is in the states' interest take account of this evolution and its consequences. This dissertation aims to suggest some ways, or mechanisms, to ensure that the normal regulatory power of states will not be found in breach of IIAs. Several potential solutions are examined.

\section{$1 \quad$ Promoting good investment governance through transparency}


Promoting good investment governance through transparency cannot be ignored in order as a means of reorganising relationships between host states and foreign investors. ${ }^{456}$ Indeed, transparency constitutes a core principle of international policy. As such, public sector transparency is an instrument for achieving goals such as enhancing the effectiveness of political processes, reducing policy uncertainty and improving the understanding of public policy. Although no commonly agreed definition exists, transparency can be defined as the obligation binding on local authorities to communicate their political goals, justify their decisions and make accessible to foreign investors all the relevant texts that concern them. This requirement is designed to allow investors to become easily informed, at less cost, about the regulatory context of their investment operation. Various sources provided their own definition of the concept of transparency. Therefore, the UNCTAD provides, through the identification of elements of good governance in investment promotion, its own definition of transparency: ${ }^{457}$

\footnotetext{
The interface between government and investors is most effective when there is timely information disclosure, easy availability of information and a helpdesk for investors. Transparency also implies greater openness to the media and the public on investment policies and practices.
}

UNCTAD goes on to detail the concept of transparency as well as the possible means by which it can be achieved: ${ }^{458}$

\begin{abstract}
It is important to ensure that the text of a law or regulation is easily available to those it is primarily addressed to. One problem faced by foreign investors in some countries, which has a bearing on transparency, is that laws are enacted in a local language not spoken at the international business level. Having authoritative investment guides in internationally recognized languages that bring together in one publication the basic requirements for setting up and operating a business in a country is one way to address that problem. In this regard, UNCTAD has cooperated with the International Chambers of Commerce (ICC) to produce a series of Investment Guides for LDCs.

Information technology (IT) and the Internet are effective tools for increasing transparency in the investment regime and informing investors and the public of expected changes in laws, regulations and procedures. The Internet could also be used to provide on-line question and answer services and to consult investors on new legislation and
\end{abstract}

\footnotetext{
${ }^{456}$ See OECD Public Sector Transparency and International Investment Policy (OECD Directorate for Financial, Fiscal and Enterprise Affairs, 11 April 2003). Available at: http://www.oecd.org/dataoecd/45/22/2506884.pdf (accessed 18 October 2008).

${ }_{457}$ UNCTAD Good Governance in Investment Promotion TD/B/COM.2/EM.15/2 (United Nations, Geneva, 2004) 4.

${ }^{458}$ Ibid, 5-6.
} 
policies. A 2000 UNCTAD survey showed that 40 per cent of IPAs provide on-line services and that most IPAs maintain specialized databases on the business environment, investors, useful contacts, etc. However, it should be noted that there are major differences between countries and that in this particular survey one-third of the LDC IPAs were not connected to the World Wide Web, while two-thirds did not have a home page.

The tribunal in Tecmed validates that the predictability component of transparency is central to the effective protection of investments. Addressing the obligation within the BIT to provide fair and equitable treatment, it held that: ${ }^{459}$

\begin{abstract}
This provision of the Agreement, in light of the good faith principle established by international law, requires the Contracting Parties to provide to international investments treatment that does not affect the basic expectations that were taken into account by the foreign investor to make the investment. The foreign investor expects the host State to act in a consistent manner, free from ambiguity and totally transparently in its relations with the foreign investor, so that it may know beforehand any and all rules and regulations that will govern its investments, as well as the goals of the relevant policies and administrative practices or directives, to be able to plan its investment and comply with such regulations.
\end{abstract}

States with more transparent policy environments will not only attract foreign investors but also improve the accountability of both actors.

Furthermore, the OECD has drawn from several international, regional and bilateral agreements a compilation of core transparency measures for the international investment community. Thus, three main transparency measures were identified: ${ }^{460}$

- Provision of information on policies of interest to international investors. ... It includes legislation, administrative rulings, judicial decisions, exceptions to national treatment and most favoured nation status, procedures for applying for authorisations, administrative practices, privatisation and monopolies.

- Clear definitions of the limits of transparency obligations (security is the most commonly cited exception); and

- Ensuring that policy information is accessible to international investors and to other governments - for example, by notifying the parties of changes to measures, by establishing national enquiry points, specialised publications or registers and web sites.

One notices that a wide range of measures of universal relevance are contained in the different agreements. In order to fulfil transparency commitments, governments need

\footnotetext{
${ }^{459}$ Tecnicas Medioambientales Tecmed S.A v The United Mexican States, above n 55, para 154.

${ }^{460}$ OECD Public Sector Transparency and International Investment Policy, above n 458, 9 and 10.
} 
to provide access to information about public sector activity as well as monitor its scope, accuracy and information. ${ }^{461}$

From the point of view of international law, the advantage of transparency is that it prevents a host government from being held responsible for unfair and inequitable treatment owing to the excessive opaqueness of its judicial and administrative system and to the unpredictable decisions due to it. Governments might still change policy plans abruptly. They might lose credibility; hence transparency measures will not have their intended effects. From an economic point of view, transparency provides positive effects in terms of performance given that the decision-making proceedings become clearer for the investor. Thanks to a good mutual understanding between administrative institutions and foreign investors, one can anticipate an important growth of investment in the states concerned. In addition, resources are granted to investors which comply with the expectations of the host state, therefore avoiding immediate losses to capital owners as well as the multinationals by a non-operational investment from the country of investment. ${ }^{462}$ Within the WTO, European Communities have indeed responded to a poll in which $71 \%$ of major European companies questioned considered the lack of transparency as a major obstacle to investment in the economy concerned.

Such a measure does not prevent the host state from changing the normative context surrounding the investment, once the latter is established. On the other hand, the transparent state sets a framework of rules under which the state will act vis-à-vis people subject to its control, whether it is in the form of an act of general application or an individual decision. Individuals are bound by rules, which are effective once they are made aware of them. Indeed, several international best practice guidelines have emerged regarding the access to information about public sector activity linked to basic fiscal, legislative and regulatory functions. ${ }^{463}$

Implementing this approach seems difficult, however. For example, the publication of laws and regulations in a source of easily accessible information has dropped even among member states of the OECD and reaches only a disappointing 18

\footnotetext{
${ }^{461}$ Ibid, 11.

${ }^{462}$ WTO Document d'orientation sur la transparence WT/WGTI/W/110.

${ }^{463}$ OECD Regulatory Policies in OECD Countries : From Intervention to Regulatory Governance (OECD, 2002) 24; OECD Best Practices for Budget Transparency PUMA/SBO(2000)6/FINAL.
} 
countries out of 26 (in 2000), an unchanged number since $1998 .{ }^{464}$ The situation is even more complex in most developing countries which often do not have the means to implement transparency criteria without outside help. ${ }^{465}$ How can one expect a developing country to make every applicable and implemented text available on the internet? Projects of ODA (Official Development Assistance) have been launched for this purpose. ${ }^{466}$ This shows that there have been developments.

The situation is not desperate: Morocco demonstrates that surprising successes are possible when it comes to transparency. Thus, thanks to an Investment Charter, the Rabat Government established in a precise way the goals of its public action for ten years starting from 1995. As a result, foreign investors enjoy a prescriptive stability for the policies which are mentioned in this document. ${ }^{467}$

\section{Establishment of a unique administrative office}

In the context of recent international investment disputes, investors often rely on incoherence between decisions and actions of different competent authorities. ${ }^{468}$ In particular, the MTD $v$ Chile case ${ }^{469}$ provides a good example of how a lack of coordination between several public entities can lead to inconsistent decision-making. The ICSID tribunal in this case held that Chile had breached the fair and equitable treatment obligation under the BIT when it approved MTD's investment, which was inconsistent with the urban policy of the government which consequently barred the

\footnotetext{
${ }^{464}$ OCDE Gestion Publique (OCDE Base de Données sur la Réglementation, Paris, 2002).

${ }^{465}$ Statistical worldwide governance indicators presenting six dimensions of governance and covering 212 countries and territories between 1996 and 2008 are provided by the World Bank at: http://info.worldbank.org/governance/wgi/index.asp (last accessed 12 August 2009). Also refer to the World Bank Governance Website at http://web.worldbank.org/WBSITE/EXTERNAL/WBI/EXTWBIGOVANTCOR/0,,menuPK:1740542 pag ePK:64168427 piPK:64168435 theSitePK:1740530,00.html and Doing Business Website at http://www.doingbusiness.org/ (last accessed 12 August 2009) for statistical surveys about the enforcement of governance initiatives in many countries.

${ }^{466}$ See in particular the project "eGovernment for Development" to the destination of countries of South America which is financed by the Department of International Development of the United-Kingdom and managed by the University of Manchester.

${ }^{467}$ Chambre de Commerce et d'Industrie de Paris Comment Accroître la Sécurité des Investissements Français à l'Etranger? (Rapport adopté par l'Assemblée Générale, Paris, 2000) 16.

${ }^{468}$ Metalclad Corporation v United Mexican States, above n 125, para 52; Compaňia de Aguas del Aconquija $S$, above n 160 .

${ }^{469}$ MTD Equity Sdn Bhd \& MTD Chile SA v Republic of Chile (2005) (Award) 44 ILM 91 (ICSID).
} 
construction work. Indirect expropriation was not found in this case, nonetheless, because the tribunal agreed with the respondent state that "an investor does not have a right to a modification of the laws of the host country., ${ }^{, 40}$ Rather, the tribunal held:

\begin{abstract}
The issue in this case is not of expropriation but unfair treatment by the State when it approved an investment against the policy of the State itself. The investor did not have the right to the amendment of the PMRS. It is not a permit that has been denied, but a change in a regulation. It was the policy of the Respondent and its right not to change it. For the same reason, it was unfair to admit the investment in the country in the first place.
\end{abstract}

The lack of any specific host state commitments to an investor, which would create legitimate expectations of the latter, was decisive in the MTD $v$ Chile decision. The multiplicity of public actors makes it difficult to implement favourable decisions for investors. Thus, central authorities of the host state may approve a project of investment but the investor may later face a denial from a local authority. ${ }^{471}$ However, a plain solution, placing all relevant public administrations in the territory of the host state in one place would be the creation of a unique public office. Thus, Morocco has made the wise choice of creating Regional Centres of Investment which allow the investor to avoid drawn-out and costly involvement with administrative authorities. Such a tool is completely transferrable to other states, including federal ones. Indeed, no administrative authority is bound to give up their competence; they are only put together within the same unit.

In addition to this aspect of accessibility, unique public offices have a noteworthy advantage in relation to international investment law: such a system would eliminate the possibility of any contradiction between the promises from one administration and the later contradictory response of another instance due to a simultaneous consultation. As a result, a violation of the fair and equitable treatment standard is unlikely to happen.

3 Avoidance of litigation: adoption of an initial consultation with investors

If the establishment of a unique public office leads to the avoidance of certain procedural incoherencies, the content of the decisions taken by the host state can remain

\footnotetext{
${ }^{470}$ Ibid, para 214.

${ }^{471}$ This is the scenario of the Metalclad case, above n 125.
} 
uncertain in with the context of international investment law. This field of law not only covers the procedural denial of justice but also in-depth public policies.

Consultations would precede binding administrative decisions that will affect the legitimate interests of investors. Thus, the state would avoid being condemned for acts that are unpredictable and contrary to legitimate interests of investors. Standardised and systematic consultation mechanisms would allow an early start in the policy making process in several stages and would without a doubt improve the predictability of the public policies concerned. It would be possible to imagine in practice an organ of consultation with a sufficient status in the context of the state's institutions and provided with useful protective mechanisms in order to minimise this issue. One can draw inspiration from the techniques developed in the context of dialogue in employment disputes:

- The participation of an "employees" organisation in developing countries, that is to say the United Nations or more particularly the UNCTAD in the consultations;

- The possible intervention of a "third-party facilitator" who is neutral during consultations, in the person of a former dignitary upon whom both parties would agree.

The ICSID Convention and Rules make extensive reference to the procedure of conciliation. ${ }^{472}$ They also make extensive reference to the procedure of conciliation which has been sparingly used in spite of its status as equivalent to arbitration tribunals. Article 28 is the first Article in the conciliation Chapter and deals with the "Request for Conciliation". Articles 29-31 deal with the "Constitution of the Conciliation Commission" and Articles 32-35 with "Conciliation Proceedings". ${ }^{473}$ Other systems for the settlement of disputes also provide for conciliation. These systems include the International Chamber of Commerce ${ }^{474}$ and UNCITRAL. ${ }^{475}$ Three requests for

\footnotetext{
${ }^{472}$ See generally Emmanuel Gaillard "Centre International pour le Règlement des Différends Relatifs aux Investissements" (1997) Chronique des sentences arbitrales, 124 Journal du Droit International 277; L C Reif "Conciliation as a Mechanism for the Resolution of International Economic and Business Disputes" (1991) 14 Fordham International Law Journal 578 and N G Ziadé "ICSID Conciliation" (1996) 13/2 News from ICSID 3.

${ }^{473}$ Christoph Schreuer The ICSID Convention: A Commentary, above n 112, 415.

${ }^{474}$ See ICC Rules of Optional Conciliation (1998) 28 ILM 231, 234.

475 Conciliation Rules of the United Nations Commision on International Trade Law (1980) GA Res. 35/52, 20 ILM 300.
} 
conciliation under ICSID have been registered so far. The first one was settled before the constitution of a conciliation commission. ${ }^{476}$ Another led to a successful settlement agreed by the parties. ${ }^{477} \mathrm{~A}$ third one did not lead to an immediate settlement. ${ }^{478}$ This infrequent use may have its source in the perception that conciliation is likely to be a waste of time, effort and money since either party can at any time withdraw from the procedure or repudiate a recommendation of the commission. ${ }^{479}$ The reasons for the scarcity of requests for conciliation lie with the perceptions and expectations of the parties, especially investors. ${ }^{480}$

In any event, a system of consultation would complement the arbitration mechanism in ICSID, which takes place after a state-investor conflict, acting as a neutral and international organ, involved before litigation ensues and therefore possibly preventing it. It would have the double advantage of preventing a number of disputes going to arbitration and improving on a permanent basis the relationships between the state and investor. An additional benefit of increasing transparency in public decisionmaking processes would be to reduce the increasing use of corruption by foreign nationals to protect their interests.

\section{$4 \quad$ Host states as true participants in the international investment process}

Even if the above suggestions do not affect the domestic sovereignty of host states, the management modes suggested would establish an innovative view of relations between foreign investor and host government, based on consultation. Such a relationship involves mutual commitments between the parties since the consultation would produce in a concrete result. A system of contractualisation is therefore necessary to allow both parties to plan their action according to a common document.

This would make the host state a true actor in the market of international investments. Indeed, unilateral instruments which are available thanks to domestic

\footnotetext{
${ }^{476}$ SEDITEX v Madagascar I (Case No. CONC/82/1) (registered 5 October 1982).

${ }^{477}$ Tesoro Petroleum Corporation v Trinidad and Tobago (Case No. CONC/83/1) (registered 26 August 1983).

478 SEDITEX v Madagascar II (Case No. CONC/94/1) (registered 13 August 1994).

${ }^{479}$ Christoph Schreuer The ICSID Convention: A Commentary, above n 112, 430.

${ }^{480}$ Ibid, 416.
} 
administrative law are not adapted anymore. The state is subject to an external control of its acts. As a result, in order to maintain some influence and to defend its interests, the state must be entirely free to proceed as a partner-negotiator vis-à-vis investors.

Yet, despite appearances, the possibility of subjecting state-investor relations to contract is not necessarily straightforward. Admittedly, state contracts already exist, but this system may face obstacles: state sovereignty and, in particular, its relation to its natural resources, undermine the compulsory state of the contract since it is concluded for a long period. The domestic distribution of competences within the state often prevents it from implementing public policy decisions vis-à-vis an external actor like a foreign investor, particularly when doing so requires legislative measures or acts by local authorities.

The result is legal insecurity for the investor and embarrassment for a state which hopes to consult with an investor, but who does not have the necessary mechanisms to ensure such a procedure. A solution would be for the host country try and establish a single authority to manage the partnership between the parties.

The legal form of the authority is not particularly important (a particular administration, a public establishment or even a private law society could fulfill the function) as long as such an authority was be able to all components of the state Administrative law should be adapted in order to allow the host state to act in that way. In a federal system, it is moreover about a common establishment of federated and federal states. These institutional models exist (see for example coordination organs between German Länder like the Zentralstelle für die Vergabe von Studienplätzen or ZVS) and do not require a constitutional amendment because the concerned authorities still discharge their respective competences. The authority should have the know-how and necessary means to be able to complete contractualisation processes as soon as possible; otherwise the authority would lose value in relation to the current system. The contracts signed by the authority and, if need be, enacted by the Parliament should be compulsory with respect to the domestic law of the state at issue and it should be possible to enforce them before the tribunals of the concerned state. Finally, the contracts of the authority should be based on general conditions which make them valid with regard to international law. This would mean that the length of the contract would be limited to a few years. 
Eventually, this would lead to concluding the contract by the provision of appointment which would allow it to be reviewed and, if need be, renew the matured contract without questioning the permanent sovereignty of the host state.

Obviously, further regulations are needed to improve the balance between investor and state interests.

\section{Proposal of a Dynamic Harmonisation of International Investment Law}

The International Institute of Sustainable Development has developed a model of an International Agreement Investment for Sustainable Development ${ }^{481}$ aiming in particular at trying to bring an adequate answer to the issue arising from the necessity of adaptating public policies related to environment and sustainable development, ${ }^{482}$ as well as a necessary integration of these concerns into the reasoning and the behavior of foreign investors. Also the model of the IISD attempts to solve the question of the wording of a solution to the issue of the conflict between a regulatory measure of a state and conflicting rights of foreign investors identified above. ${ }^{483}$ Lastly, it seeks to bring treat the underlying issue of vague attempts of sovereign strengthening. ${ }^{484}$

The International Institute of Sustainable Development has drafted an IIA after several years of preliminary work, research, consultations and presentations to a council of experts. ${ }^{485}$ The extent of this model is of course broader than the subject of the present dissertation.

The model is designed to constitute the standard for the signature of future IIAs. ${ }^{486}$ It is different from existing bilateral agreements, in particular in how it reviews the respective positions of the three major parties which are the investor, the host state and the country of origin.

\footnotetext{
${ }^{481}$ Aaron Cosbey, Howard Mann, Luke Eric Peterson and Konrad Von Moltke Model International Agreement on Investment for Sustainable Development, above n 375.

${ }^{482}$ See Chapter III of the present dissertation, Section A, 3, 41.

${ }^{483}$ See Chapter III of the present dissertation, Section B, 82.

${ }^{484}$ See Chapter IV of the present dissertation, Section A, 91.

${ }^{485}$ See www.iisd.org/pdf/2005/investment_model_int_agreement.pdf (last accessed 8 January 2009).

${ }^{486}$ Several dozen of agreements were drawn from the model of agreement of the IISD. See: http://www.iisd.org/pdf/2005/investment_model_int_handbook.pdf VI (last accessed 8 January 2009).
} 
Basically, the model of agreement of the IISD has, as a higher objective, to allow the harmonious combination of an international protected investment (but accountable) with a sustainable development for areas of origin and reception of international investments. Therefore, the purpose of this section is to briefly describe the main provisions of the model, then to analyse what this model does not deal with and to conclude with a recommendation for decision makers and scholars of a conceptual alternative intended to address certain lacunae and drawbacks of the current basis of IIAs.

$1 \quad$ The all-embracing and innovative approach of the IISD

(a) Brief summary of the model of IIA suggested by the IISD

The model of agreement suggested by the IISD is a multilateral agreement: it considers the situation of the foreign investor as well as the situation of the host state and of the country of origin, which is innovative, in particular as regards the involvement of the latter. ${ }^{487}$

This model includes definitions of major concepts (act of investment, actors of the agreement...). ${ }^{488}$ In addition, it states the principles of security, also major for international investment. The suggested IIA supports the requirement of a sustainable development, in the North as well as in the South, ${ }^{489}$ by not omitting the social facet of the international investment; the encouragement of a protected international investment and the balance that needs to exist between the rights and obligations of the three main actors of international investment (investor, host and home states). ${ }^{490}$

\footnotetext{
${ }^{487}$ Loewen Group Inc and Raymond L Loewen v United States of America (2003) (Award) 42 ILM 811 (NAFTA/ICSID (AF)), para 72 .

${ }^{488}$ Aaron Cosbey, Howard Mann, Luke Eric Peterson and Konrad Von Moltke Model International Agreement on Investment for Sustainable Development, above n 375, Article 2.

${ }^{489}$ See the pending decision: Southern Bluefin Tuna Case (Australia and New Zealand $v$ Japan) (Jurisdiction and Admissibility) [2000] Arbitral Court constituted under Annex VII of the United Nations Convention one the Law of Sea (UNCLOS). Available at: http://www.temple.edu/lawschool/drwiltext/docs/SBT_Award\%20on\%20Jurisdiction.pdf (last accessed 10 February 2009).

${ }^{490}$ See the pending decision in a former award: The Australia and New Zealand v Japan Southern Bluefin Tuna (Jurisdiction and Admissibility) Award of the first Law of the Sea Convention Annex VII Arbitral Tribunal 16, International Newspaper of Navy and Coastal Law (2001) 239-294.
} 
In addition, the model of the IISD presents a formal procedure of good governance, ${ }^{491}$ as well as a procedure of resolution of litigations that might occur. ${ }^{492}$ This procedure considers, in an original way, the creation of ad hoc institutions. ${ }^{493}$

(b) Analysis of what the model of IIA of the IISD does not consider

With regard to the possible reluctance of certain states to ratify whole or part of the elaborated model, the IISD is silent about the possibility of a partial ratification of the model of agreement. The model develops a whole concept which appears to have to be accepted as such. It does not include a hierarchy with the stated articles. A shortened version is not considered, or even a version including options for drafting. Thus, there is not a "Plan B". A state's choice is reduced, a priori, to the binary choice of complete membership to the presented model or complete rejection. In order to mitigate this major disadvantage, a simplified conceptual alternative is presented further in section 2.

As for the principles of security of international investment, Articles 5, 6, 7 and 21 of the model of agreement respectively deal with the national treatment of the investment, the most-favoured nation treatment, fair and equitable treatment of the investment and the prohibition to expropriate without prompt, adequate and effective compensation.

Article 19 does not retain, for its part, the protection offered by the umbrella provisions. The explanation for this choice is provided in the Negotiator's Handbook coming with the model of agreement. The authors specify that: ${ }^{494}$

Rather, the obligations on host states are made specific and, we hope, clear. IISD believes it is inappropriate to grant to an international Dispute Settlement Body full jurisdiction to hear any type of complaint for breach of contract, or breach of a permit, etc. as a direct breach of an international agreement through the umbrella provision. We thus suggest that this type of provision not be included among the host state obligations.

\footnotetext{
491 Aaron Cosbey, Howard Mann, Luke Eric Peterson and Konrad Von Moltke Model International Agreement on Investment for Sustainable Development, above n 375, Article 15.

${ }^{492}$ Ibid, Part 8: Institutions.

${ }^{493}$ Ibid, Part 9: Dispute Prevention and Settlement.

${ }^{494}$ Aaron Cosbey, Howard Mann, Luke Eric Peterson and Konrad Von Moltke IISD Model International Agreement on Investment for Sustainable Development, Negociator's Hanbook (2ed, IISD, Winnipeg, Manitoba, 2006) 33.
} 
It is noted that Article 2 of the model of agreement approaches only in a generic way, and thus imperfectly, the scope of investments: ${ }^{495}$ "tangible property, including real property; and intangible property, including rights, such as leases, mortgages, liens and pledges on real property." However, what constitutes a major part of the present and future of the investments of companies, namely intellectual property (trademarks, patents, software and so on) is missing.

Even if this is a relatively narrow area of law, it has featured a lot of disputes ${ }^{496}$ and litigation ${ }^{497}$ which could have justified an attempt to explicitly mention and incorporate it within the framework of work of the IISD.

Is it useful to point out the interest of such an explicit mention taking into consideration the obligations and rights of the host states and countries of origin bound by the IIA? The proposal which follows intends to include this matter in a universal way.

\section{$2 \quad$ New key issues on investor-state relationship}

In order to adequately address some of the issues identified above, it this dissertation suggests the insertion in the preamble of international agreements on investments of a series of paragraphs relating to the right to security of international investments, under conditions.

The preamble of IIAs is very important. The IISD refers to it in its model of agreement, taking into consideration the goals of the negotiation of the agreement. In addition, the IISD deliberately notes (in the comment in the Negotiator's Guide) that the preamble often makes it possible to guide interpretation by the parties and the other people affected by the agreement of investment, including within the framework of the

\footnotetext{
495 Ibid, Article 2, C, IV.

496 Thus the patentability of softwares gave rise to interesting debates at the European commission as from 2003 with the preparation of a draft for adopting a directive promoting the recognition of the right to patentability of computer-implemented inventions but finally lead to a negative vote of the European Parliament in 2005: see http://www.europarl.europa.eu/sides/getDoc.do;jsessionid=CEF478A13FD0F7E22BE3442A11E0C1E4.no de1?language $=\mathrm{EN} \&$ pubRef=-//EP//TEXT+PRESS+DN-20050706-1+0+DOC+XML+V0//EN_ (last accessed 10 February 2009).

${ }^{497}$ See Helnan International Hotels A/S v Arab Republic of Egypt (2008) (Award) ICSID Case No. ARB/05/09, paras 78 and following at: www.iisd.org/pdf/2007/itn_helnan.pdf (last accessed 10 February 2009).
} 
settlement of disputes. Several arbitrations concerning international investment have been concerned with provisions contained in the preamble. ${ }^{498}$

While failing to establish the heavy (but tempting) architecture of the model of IIA proposed by the IISD, it is interesting to think of the inclusion of a frame-system that would constitute the right counterpart to the formal recognition of the right of security of international investments in the preamble of every IIA.

Such a new form of preamble might state:

"The fundamental rights (national treatment of the investment, the most-favoured nation treatment, fair and equitable treatment of the investment, prohibition to expropriate without prompt, adequate and effective compensation, the possibility of transferring credits) of the security of international investors are guaranteed by this agreement:

- in return for which the respect, in good faith, of obligatory liabilities, as well as values and obligations such as defined or quoted by (or "to which refer") texts clarifying the activity of international organisations or institutions (UN, UNESCO, OECD, WTO, ILO, EU, ECHR...) in the geographical or operational field of which any recipient of the present agreement acts or joins the above listed organisations; such responsibilities, values and obligations are recognised and accepted as constituting the general framework of intervention of all the recipients to the agreement,

- $\quad$ and except prevailing requirement of public interest."

The above approach would have certain attributes and advantages. The importance of the protection of investments is stated from the outset. Moreover, reference is made to "obligatory responsibilities" which must be respected. By this expression, the project intends to answer the mentions of the risks that investors have to face, but also the internationally practiced and shared legal provisions (for example the "responsibility of the manufacturer"). Values and obligations to respect are mentioned and are contained in

${ }^{498}$ MTD Equity Sdn Bhd \& MTD Chile SA v Republic of Chile, above n 469, para 113. 
a corpus of rules relating to the operation and the activity - in perpetual evolution - of international agencies of reference and with normative goals. Explicit mention is made of the requirement that the participants act bona fide. A non-constraining reference is made to international agencies. It is completely possible to limit the list. The "recipients" of the agreement are pointed out. Therefore in a generally accepted meaning it refers to any person or organization who has a legitimate interest in the investment and the international agreement. Finally, the introduction of a reference to respect for the "prevailing requirement of public interest" is included. This concept results from the decisions of the European Court of Human Rights (ECHR). ${ }^{499}$ It is inspired by the concern of prevailing law and order, according to the reason that the general interest (for example the common good) must prevail over private interests. This is concerned with the commission of offences and the protection of the security and essential interests of the host state. One could, for simplification, imagine another formulation: "except in the event of commission of offences whose nature and particular gravity are likely to be criminally punished."

Such a proposal is intended to act as an intermediary between the various drafts of existing bilateral agreements and the - still incomplete - very structured draft project of the IISD.

The essence is to try to develop the matter, by proposing a general provision which focuses on the symmetrical aspect of the rights and obligations of the various recipients. Therefore, the present proposal appears to constitute an honest compromise making possible to frame the draft in relation to the constant evolution of new international investment agreements.

\footnotetext{
${ }^{499}$ See in particular the case Roemen and Schmit v Luxembourg (Judgement) ECHR (Fourth Section) (no. 51772/99) $(25$ February 2003) para 46: http://cmiskp.echr.coe.int////kp197/viewhbkm.asp?action=open\&table=F69A27FD8FB86142BF01C1166 DEA398649\&key=3538\&sessionId=16338131\&skin=hudoc-en\&attachment=true $\quad$ (last $\quad$ accessed 16 February 2009).
} 
The comprehensive analysis of the foreign investor-host state conflicting rapport and highlighted in Chapter III clearly demonstrates a lack of balance in most of international investment agreements today. Such treaties have a tendency to focus exclusively on foreign investor rights and protection. In addition, there is no frequent space for provision of the right of host states to take regulatory measures in order to achieve public policy or development objectives. One can only but notice that such an unbalanced relationship between the main actors of an investment treaty involves some negative consequences for developing countries. Certainly, we have reached a high number of over 250 known arbitrations mainly brought by investors against host states. A great number of awards result in imposing excessive financial costs to developing country governments which cannot in turn implement their regulatory policies. In this manner, an American lawyer describes investment agreements as: ${ }^{500}$

\footnotetext{
an open invitation to unhappy investors, tempted to complain that a financial or business failure was due to improper regulation, misguided macroeconomic policy or discriminatory treatment by the host government and delighted by the opportunity to threaten the national government with a tedious expensive arbitration
}

Answering the most fundamental question of what level of protection is needed to ensure a proper balance between legitimate rights of investors and public interest of host states requires advocating for several practical solutions.

The main requirement is dealing with both public policy requirements and to new obligations from international investment law, the state would have to adapt its decisionmaking procedures to increase transparency. Thus, for a public policy required to be spotless with respect to international investment law, it could be useful for the state to establish a unique organ to take responsibility for an initial consultation with investors before the final decision. This would avoid a policy newly instituted by the authorities of a host state infringing legitimate expectations of a foreign investor. These expectations have recently become the central notion of the security of international investments.

\footnotetext{
${ }^{500}$ William D. Rogers "Inter-American Development Bank Conference on Commercial Alternative Dispute Resolution in the XXI Century: The Road Ahead for Latin America and the Caribbean" Speech to InterAmerican Bank Conference, 26-27 October 2000) 2.
} 
Insofar as it encourages extensive reform of the administration of host countries, international investment law can appear to be a trouble-maker. Nevertheless, these new developments encourage transparency, institutional development and therefore the credibility of the public management of host states. These elements promote competitiveness and the sustainable development of economies which benefit from it. If they are made in a constructive way, adaptations to the evolution of international investment law might simultaneously serve the foreign investor and the general interest. International security of investments therefore is inextricably linked to an inevitable transformation of the state where domestic tools become insufficient in many respects.

The International Institute for Sustainable Development Model Investment Treaty provides interesting and original alternative provisions. However, such a multilateral model of investment treaty remains an indicator of the evolution of this area of law and at the moment is not binding.

Since this model is not in force, it might be found other realistic ways of ensuring a better balancing of the rights and interests of foreign investors and respect for legitimate public concerns. ${ }^{501}$ In negotiating new IIAs or revising their current ones, countries need to legitimately consider new concerns such as environment and social issues. One way of doing so is for states to clarify uncertain legal terms where interpretation provided by tribunals might be inconsistent such as 'foreign investor', 'fair and equitable treatment' or 'indirect expropriation.' New BITs may also precise that certain environmental or public security measures do not amount to indirect expropriation. ${ }^{502}$ Lastly, another tempting way would be to include the right to security of international investments as a general provision in preambles of IIAs.

\footnotetext{
${ }^{501}$ UN CTAD "Balancing Private and Public Interests in International Investments IAs" UNCTAD Expert Meeting on Development Implications of International Investment Rule Making (28-29 June 2007) 6.

${ }^{502}$ See the 2004 US Model BIT, above n 326, Annex B.
} 
$\mathrm{ACP}$

AJIL

Am Rev Intl Arb

Arb Intl

ASEAN

BIT

BYIL

Can Bus L J

CEPMLP I J

Chi J Intl L

Dev L J

EC Treaty

Envtl L Rep

FCN Treaty

FDI

FET

FTA

GATT

Golden Gate U L Rev

ICC

ICCPR

ICESCR

ICJ

ICLQ

ICSID

ICSID Rev - FILJ

IIA
IISD
ILC
ILO
IMF
Ind 1 J
JDI
JIEL
JWIT
Law \& Pol'y Int'l Bus
MAI
MERCOSUR

African, Caribbean and Pacific Group of States

American Journal of International Law

American Review of International Arbitation

Arbitration International

Association of Southeast Asian Nations

Bilateral investment treaty

British Yearbook of International Law

Canadian Business Law Journal

Centre for Energy, Petroleum and Mineral Law and

Policy Internet Journal

Chicago Journal of International Law

Development Law Journal

Treaty establishing the European Community

Environmental Law Reporter

Friendship-Commerce-Navigation Treaty

Foreign direct investment

Fair and Equitable Treatment

Free Trade Agreement

General Agreement on Tariffs and Trade

Golden Gate University Law Review

International Chamber of Commerce

International Covenant on Civil and Political Rights

International Covenant on Economic, Social and

Cultural Rights

International Court of Justice

International \& Comparative Law Quaterly

International Centre for Settlement of Investment

Disputes

International Centre for Settlement of Investment

Disputes Review Foreign Investment Law Journal

International investment agreement

International Institute for Sustainable Development

International Law Commission

International Labour Organisation

International Monetary Fund

Industrial Law Journal

Journal du Droit International

Journal of International Economic Law

Journal of World Investment \& Trade

Law and Policy in International Business

Multilateral Agreement on Investment

Mercado Común del Sur (Southern Common Market) 
MFN

NAFTA

NGO

N Y U Envtl L J

OECD

OJEU

RIAA

RIW

TDRIQR

TNC

TPA

TDM

TRIMs

TRIPS

Rights

UCDJILP

UNCITRAL

UNCTAD

UNCTC

UNDP

UNGA

UNTS

USCTR

Va J Intl L

VCLT

WIR

WTO

WWII
Most-favoured-nation treatment

North American Free Trade Agreement

Non Governmental Organisation

New York University Environmental Law Journal

Organisation for Economic Co-operation and Development

Official Journal of the European Union

Reports of International Arbitral Awards

Recht der Internationalen Wirtschaft

Thailand Development Research Institute

Transnational Corporation

Trade Protection Agreement

Transnational Dispute Management

Trade-Related Investment Measures

Trade-related Aspects of Intellectual property

UC Davis Journal of International Law and Policy

United Nations Commission on International Trade Law

United Nations Conference on Trade and

Development

United Nations Centre on Transnational

Corporations

United Nations Development Programme

United Nations General Assembly

United Nations Treaty Series

United States Claim tribunal

Virginia Journal of International Law

Vienna Convention on the Law of Treaties

World Investment Report

World Trade Organisation

World War II 


\section{TABLE OF CASES}

\section{ICSID}

ADC Affiliate Limited and ADC \& ADMC Management Limited v Republic of Hungary (Cyprus v Hungary) (2006) ICSID Case No. ARB/03/16.

Aguas del Tunari SA Republic of Bolivia ICSID Case No. ARB/02/03 (21 October 2005) (Decision on Respondent's Objections to Jurisdiction).

Amco Asia Corp v Republic of Indonesia (1986) (Decision on Annulment) 1 ICSID Rep 509 (ICSID).

American Independent Oil Company (Aminoil) v State of Kuwait (1982) 21 ILM 976.

Archer Daniels Midland Co. \& Tate Lyle Ingredients Americas, Inc v United Mexican States (2004).

Azinian, Davitian \& Baca v United States of Mexico (1999) (Award) 39 ILM 537 (NAFTA).

Azurix Corp v Argentine Republic (2006) (Award) ICSID Case No. ARB/01/12.

Biwater Gauff (Tanzania) Ltd. $v$ United Republic of Tanzania ICSID Case No. $\mathrm{ARB} / 05 / 22$.

Československa Obchodni Banka, a.s. v The Slovak Republic (1999) (Decision on Objections to Jurisdiction) 14 ICSID Rev.

CME Czech Republic BV (The Netherlands) v Czech Republic (2001) (Partial Award) 9 ICSID Rep 121 (UNCITRAL).

CMS Gas Transmission Co v Republic of Argentina (2003) (Jurisdiction) 42 ILM 788 (ICSID).

CMS Gas Transmission Co v Republic of Argentina (2005) (Award) 44 ILM 1205 (ICSID).

Compaňia de Aguas del Aconquija SA and Vivendi Universal v Argentine Republic (2002) (Decision on Annulment) 41 ILM 1135 (ICSID).

Compaňia Del Desarrollo de Santa Elena, SA v Republic of Costa Rica (2000) (Award) 39 ILM 1317 (ICSID). 
Consortium RFCC v Kingdom of Morocco (2003) (Award) 20 ICSID Rev-FILJ 391 (ICSID).

Corn Products International Inc v Mexican States (2008) (Decision on Responsibility) ICSID Case No. ARB(AF)/04/01.

El Paso Energy International Company v Argentine Republic (2006) (Decision on Jurisdiction) (ICSID Case No. ARB/03/15).

Ethyl Corp $v$ Government of Canada (1999) (Jurisdiction) 38 ILM 708 (NAFTA/UNCITRAL).

Eureko BV v Republic of Poland (2005) (Partial Award) 12 ICSID Rep 335 (UNCITRAL).

Fedax NV v Republic of Venezuela (1998) (Award) 37 ILM 1391 (ICSID).

Feldman v United Mexican States (2002) (Award) 42 ILM 625 (NAFTA/ICSID (AF)).

Generation Ukraine Inc v Ukraine (2003) (Award) 44 ILM 404 (ICSID).

Goetz \& others $v$ Republic of Burundi (1999) (Award) 15 ICSID Review-FILJ 457 (ICSID).

Grand Rivers Enterprises Six Nations, Ltd et al, v USA.

Helnan International Hotels A/S v Arab Republic of Egypt (2008) (Award) ICSID Case No. ARB/05/09.

International Thunderbird Gaming Corporation v United Mexican States (2006) (Award) (NAFTA/UNCITRAL).

Klöckner Industrie-Anlagen GmbH and others $v$ United Republic of Cameroon and Société Camerounaise des Engrais (1985) (Decision on Annulment) 2 ICSID Rep 95.

$L G \& E$ Energy Corp, $L G \& E$ Capital Corp, and $L G \& E$ International Inc v Argentine Republic (2006) (Decision on Liability) 46 ILM 36 (ICSID).

Loewen Group Inc and Raymond L Loewen v United States of America (2003) (Award) 42 ILM 811 (NAFTA/ICSID (AF)).

Metalclad Corp v United Mexican States ICSID (2000) (Award) 40 ILM 36 (NAFTA).

Methanex Corp v United States of America (2005) 44 ILM 1345 (NAFTA/UNCITRAL). 
Methanex Corp v United States (15 January 2001) (Decision of the Tribunal on Petitions from Third Persons to Intervene as Amicus Curiae).

Middle East Cement Shipping and Handling Co SA v Arab Republic of Egypt (2002) (Award) 7 ICSID Rep 173 (ICSID).

MTD Equity Sdn Bhd \& MTD Chile SA v Republic of Chile (2005) (Award) 44 ILM 91 (ICSID).

Piero Foresti, Laura de Carli \& others $v$ South Africa Petition for Limited Participation as Non-Disputing Parties in Terms of Articles 41(3), 27, 39 and 35 of the Additional Rules (ICSID) Case ARB(AF)/07/01 (17 July 2009).

Pope \& Talbot Inc v Government of Canada (2000) (Interim Award) 40 ILM 258 (NAFTA/UNCITRAL).

PSEG Global Inc v Republic of Turkey (2007) (Award) ICSID Case No. ARB/02/5.

Revere Copper and Brass Inc v Overseas Private Investment Corp (OPIC) (Award) (1980) 56 ILR 258.

Saipem SPA v The People's Republic of Bangladesh (2007) (Decision on Jurisdiction and Recommendation on Provisional Measures) ICSID Case No. ARB/05/07.

Saluka Investments BV (The Netherlands) v Czech Republic (2006) (Partial Award) (UNCITRAL).

SD Myers Inc v Government of Canada (2000) (First Partial Award) 40 ILM 1408 (NAFTA/UNCITRAL).

SGS Société Générale de Surveillance SA v Islamic Republic of Pakistan (2003) (Jurisdiction) 42 ILM 1290 (ICSID).

SGS Société Générale de Surveillance SA v Republic of the Philippines (2004) (Jurisdiction) 8 ICSID Rep 515 (ICSID).

Siemens AGv Argentine Republic (2007) (Award) ICSID Case No. ARB/02/8.

South Pacific Properties (Middle East) Ltd (SPP) v Arab Republic of Egypt (1992) (Award) 32 ILM 986 (ICSID).

Suez, Sociedad General de Aguas de Barcelona SA v Vivendi Universal SA v Argentine Republic ICSID Case No. ARB/03/19 (19 May 2005) (Order in Response to a Petition for Transparency a Participation As Amicus Curiae). 
Técnicas Medioambientales Tecmed SA v United Mexican States (2004) (Award) 43 ILM 133 (ICSID (AF)).

Texaco Overseas Petroleum Co v Libyan Arab Republic (1978) (Award) 17 ILM 3 (Ad Hoc Arb).

United Parcel Service of America Inc v Government of Canada (17 October 2001) (Decision of the Tribunal on Petitions for Intervention and Participation as Amici Curiae).

Waste Management Inc v United Mexican States ('Waste Management II') (2004) (Award) 43 ILM 967 (NAFTA/ICSID (AF)).

\section{ICJ}

Elettronica Sicula S.p.A. (ELSI) (United States v Italy) (Jurisdiction and Admissibility) [1989] ICJ Rep 15.

Gabčíkovo-Nagymaros Project (Hungary v Slovakia) (Judgement) [1997] ICJ Rep 3.

Military and Paramilitary Activities in and against Nicaragua (Nicaragua $v$ United States of America) (Jurisdiction and Admissibility) [1986] ICJ Rep 392.

Oil Platforms Case (Islamic Republic of Iran v United States of America) (Preliminary Objections) [1996] ICJ Rep 803.

\section{PCIJ}

The Case SS “Lotus” (France v Turkey) (Judgement) [1927] PCIJ (Series A, No 10) 1.

The Chorzów Factory Case (Germany v Poland) (Merits) [1928] PCIJ (Series A, No 17) 1.

The Oscar Chinn Case (United Kingdom v Belgium) (Judgement) [1934] PCIJ (Series A./B, No 63) 1.

\section{GATT}

GATT Dispute Panel Report on Canada Measures Affecting Exports of Unprocessed Herring and Salmon, 22 March 1988, GATT B.I.S.D. (35 ${ }^{\text {th }}$ Supp) at 98 (1988)

GATT Dispute Panel Report on Thailand Restrictions on Importation of and Internal Taxes on Cigarettes, 7 November 1990, GATT B.I.S.D. (37th Supp) at 200 (1990) 
GATT Dispute Panel Report on U.S. Prohibition of Imports of Tuna and Tuna Products from Canada, 22 February 1982.

GATT Dispute Panel Report on U.S. Restrictions on Imports of Tuna, 3 September 1991, GATT B.I.S.D. (39th Supp) at 155 (1991) 30 I.L.M. 1594 (1991)

GATT Dispute Panel Report on U.S. Restrictions on Imports of Tuna, 16 June 199433 I.L.M. 839

GATT Dispute Panel Report on U.S. Taxes on Automobiles (1994) 33 I.L.M. 1399 (1994).

\section{WTO}

European Communities - Measures Affecting Asbestos and Asbestos -Containing Products, WT/DS135/AB/R (2001) (Appellate Body).

U.S. - Standards for Reformulated and Conventional Gasoline, WT/DS2/AB/R (1996) (Appellate Body).

U.S. - Import Prohibition of Certain Shrimp and Shrimp Products, WT/DS/AB/R (1998) (Appellate Body).

U.S - Import Prohibition of Certain Shrimp and Shrimp Products, Recourse to Article 21.5 by Malaysia, WT/DS58/AB/RW (2001) (Appellate Body).

\section{OTHER JUDICIAL DECISIONS}

Alcoa Minerals Jamaica v Jamaica (1975) Court of Appeal of Jamaica (Decision on Jurisdiction) 4 Y B Com Arb 206.

Brewer, Moller and Co v Venezuela (Germany v Venezuela) Mixed Claims Commission (1903) X RIAA 423.

Emanuel Too v Greater Modesto Insurance Associates and the United States of America (1989) 23 Iran-USCTR 378.

EnCana Corporation v Republic of Ecuador, LCIA Case No UN3481 (February 2006).

In the case of James and Others (21 February 1986) ECHR (Judgment).

Kügele v Polish State (1931-1932) Upper Silesian Arbitral Tribunal, Annual Digest 6, 69. 
LFH Neer \& Pauline Neer (USA) v United Mexican States (1926) U.S.-Mexico Claims Commission IV RIAA 60.

Link-Trading Joint Stock Company v Department for Customs Control of Republic of Moldova (2002) (Award) (UNCITRAL).

Metalclad Corp v United Mexican States (2001) BCSC 664, 5ICSID 236 (Supreme Court of British Columbia).

Norwegian Shipowners' Claims Norway v United States of America (13 October 1922) PCA, I RIAA 307.

Occidental Exploration and Production Co v Republic of Ecuador (2004) LCIA, Case No UN3467 (UNCITRAL).

Roemen and Schmit v Luxembourg (Judgement) ECHR (Fourth Section) (no. 51772/99) (25 February 2003).

SEDITEX v Madagascar I (Case No. CONC/82/1) (registered 5 October 1982).

SEDITEX v Madagascar II (Case No. CONC/94/1) (registered 13 August 1994).

Southern Bluefin Tuna Case (Australia and New Zealand v Japan) (Jurisdiction and Admissibility) [2000] Arbitral Court constituted under Annex VII of the United Nations Convention one the Law of Sea (UNCLOS).

Starrett Housing Corp v Islamic Republic of Iran (Interlocutory Award) (1983) 4 IranUSCTR 122.

Tesoro Petroleum Corporation $v$ Trinidad and Tobago (Case No. CONC/83/1) (registered 26 August 1983).

Tippetts, Abbett, McCarthy, Stratton v TAMS-AFFA Consulting Engineers of Iran, The Government of the Islamic Republic of Iran (1984) 6 Iran-USCTR 219.

Yaung Chi Oo Trading Pte Ltd v Government of the Union of Myanmar (Award) (2003) ASEAN Arbitral Tribunal 42 ILM 540. 


\section{BIBLIOGRAPHY}

\section{PRIMARY SOURCES}

\section{A Legislation}

\section{Multilateral Treaties}

Agreement on Trade-Related Investment Measures (TRIMS) (signed 15 April 1994) 1868 UNTS 186.

ASEAN Agreement for the Promotion and Protection of Investments (ASEAN Agreement) (signed 15 December 1987) (1988) 27 ILM 612, III Compendium II 293.

Charter of the United Nations (UN Charter) (signed 26 June 1945, entered into force 24 October 1945) 59 Stat 1031: TS 993; 3 Bevans 1153.

Convention for the Protection of Human Rights and Fundamental Freedoms (European Convention on Human Right, ECHR) (signed 4 November 1950, entered into force 3 September 1953) 213 UNTS 221.

Convention on International Trade in Endangered Species of Wild Fauna and Flora (CITES) (signed in Washington 3 March 1973, amended in Bonn 22 June 1979) 993 UNTS 243.

Convention on the Recognition and Enforcement of Foreign Arbitral Awards (New York Convention) (adopted 10 June 1958, entered into force 7 June 1959) 330 UNTS 38.

Convention on the Settlement of Investment Disputes between Sates and Nationals of other States (ICSID Convention) (signed 18 March 1965, entered into force 14 October 1966) 575 UNTS 159.

Energy Charter Treaty (ECT) (signed 17 December 1964, entered into force 16 April 1998) 2080 UNTS 100.

General Agreement on Tariffs and Trade (GATT) (30 October 1947) 55 UNTS 194.

General Agreement on Trade in Services (GATS) (15 April 1994) 1869 UNTS 299.

General Agreement on Tariffs and Trade: Multilateral Negotiations: Final Act Embodying the Results of the Uruguay Round of Trade Negotiations (WTO Agreement) (signed 15 April 1994, entered into force 1 January 1995) 33 ILM 1126.

ILO Declaration on Fundamental Principles and Rights at Work (June 1998) 37 ILM 1233. 
ILO Tripartite Declaration of Principles Concerning Multinational Enterprises and Social Policy (adopted 16 November 1977 and amended in November 2000) 17 ILM 422.

Kyoto Protocol of the United Nations Framework Convention on Climate Change (UNFCCC or FCCC) (adopted 11 December 1997, entered into force 16 February 2005) 37 ILM 22.

Multilateral Agreement on Investment (MAI) (Final Unadopted Negotiating Draft, OECD, 22 April 1998 DAFFE/MAI (98)) 7 REV 1.

North American Free Trade Agreement (NAFTA) (adopted 17 December 1992, entered into force 1 January 1994) 32 ILM 289.

OECD Convention on Combating Bribery of Foreign Public Officials in International Business Transactions (adopted by the Negotiating Conference on 21 November 1997, entered into force 15 February 1999) 37 ILM 1.

OECD Draft Convention on the Protection of Foreign Property and Resolution of the Council of the OECD on the Draft Convention (1967) 7 ILM 117.

Statute of the International Court of Justice (ICJ Statute) (signed 26 June 1945, entered into force 24 October 1945) 3 Bevans 1179; 59 Stat 1055; TS No 993.

The Declaration on Environment and Development (Rio Declaration) (14 June 1992) 31 ILM 874.

Treaty establishing a Constitution for Europe (European Constitution or TCE) (16 December 2004) OJEU 47 C310/1.

United Nations Commission on International Trade Law (UNCITRAL) Arbitration Rules (15 December 1976) UN Doc A/31/98.

Vienna Convention on the Law of Treaties (VCLT, the Vienna Convention) (signed 23 May 1969, entered into force 27 January 1980) 1155 UNTS 331.

World Bank Guidelines on the Treatment of Foreign Direct Investment III Compendium I 247.

\section{Bilateral Treaties}

Accord entre le Gouvernement de la République Française et le Gouvernement de la République Populaire de Mongolie sur l'encouragement et la protection réciproques des investissements (France- République Populaire de Mongolie) (signed 8 November 1991, entered into force 22 December 1993) JO 24 March 19944469.

Agreement for the Promotion and Protection of Investments (Canada-Uruguay) (29 October 1997). 
Agreement for the Promotion and Reciprocal Protection of Investments (Argentine Republic-New Zealand) (27 August 1999).

Agreement on Encouragement and Reciprocal Protection of Investments (Kingdom of the Netherlands-Republic of Paraguay) (29 October 1992).

Agreement on Encouragement and Reciprocal Protection of Investments (NetherlandsCzech and Slovak Federal Republics) (signed 25 November 1998, not yet entered into force) Tractatenblad 1998, 283.

Agreement on the Promotion and Protection of Investments (Finland-Nicaragua) (2003).

Agreement on the Reciprocal Promotion and Protection of Investments (BelgoLuxembourg Economic Union-Ethiopia) (2003).

Belgo-Luxemburg Economic Union Model BIT.

Canada-Chile Free Trade Agreement (signed 5 December 1996, entered into force 5 July 1997).

Canadian Model Foreign Investment Protection Agreement (FIPA or Canada Model BIT) Agreement Between Canada and for the Promotion and Protection of Investments (2004).

Chile-European Free Trade Association FTA (Chile-EFTA FTA) (signed 26 June 2003 and entered into force 1 December 2004).

Colombia-Mexico-Venezuela Free Trade Agreement (1900).

Mexico-Chile Free Trade Agreement (1998).

Mexico-Costa Rica Free Trade Agreement (1994).

Mexico-Nicaragua Free Trade Agreement (1992).

New Zealand - China Free Trade Agreement (NZ-China FTA) (signed 7 April 2008).

Protocol of the Agreement on the Promotion and Reciprocal Protection of Investments (United Mexican States-Federal Republic of Germany) (1998).

Treaty between the Government of the United States of America and The Government of [Country] Concerning the Encouragement and Reciprocal Protection of Investment - US Model BIT (2004).

Treaty Concerning the Encouragement and Reciprocal Protection of Investment (United States of America-Republic of El Salvador) (10 March 1999). 
Treaty Concerning the Encouragement and Reciprocal Protection of Investment (United States of America-Bolivia) (signed 17 April 1998, entered into force 6 June 2001) Senate Treaty Doc 106-25.

Treaty Concerning the Encouragement and Reciprocal Protection of Investment (United States of America-Republic of Nicaragua) (1 July 1995) Senate Treaty Doc 106-33.

Treaty Concerning the Encouragement and Reciprocal Protection of Investment (United States of America-Republic of Ecuador) (signed 27 August 1993, entered into force 11 May 1997) Senate Treaty Doc 103-15.

Treaty Concerning the Reciprocal Encouragement and Protection of Investment (USArgentina) (signed 14 November 1991, entered into force 20 October 1994) Senate Treaty Doc 103-02.

Treaty of Amity, Economic Relations and Consular Rights between the United States of America and the Islamic Republic of Iran (15 August 1955) 8 UST 899 (entered into force 16 June 1957) ('the Treaty') (quoted in: Oil Platforms Case (Islamic Republic of Iran $v$ United States of America) [2003] (Merits) ICJ Rep 161).

Treaty of Friendship Commerce and Navigation between the United States of America and Liberia (21 October 1962).

Treaty of Friendship, Commerce and Navigation (United-States-Italy) (2 June 1948).

Treaty of Friendship, Commerce and Navigation between the United States and Nicaragua (21 January 1956) (quoted in: Military and Paramilitary Activities in and against Nicaragua (Nicaragua v United States) (Jurisdiction and Admissibility) [1986] ICJ Rep 392).

United States-Australia Free Trade Agreement (entered into force on 1 January 2005).

United States-Central America Free Trade Agreement (CAFTA) (signed 28 January 2004 between Costa Rica, El Salvador, Guatemala, Honduras and Nicaragua).

United States-Chile Free Trade Agreement (2003).

United States-Morocco Free Trade Agreement (signed 15 June 2004).

United States-Peru Trade Protection Agreement (TPA) (2006).

United States-Singapore Free Trade Agreement (signed 6 May 2003 and entered into force 1 January 2004).

Vertrag zwischen der Republic Kroatien und der Bundesrepublik Deutschland über die Förderung und den gegeinseitigen Schutz von Kapitalanlagen (Germany-Croatia) (signed 21 March 1997). 


\section{SECONDARY SOURCES}

A Texts

Aldrich, George $\mathrm{H}$ The jurisprudence of the Iran-United States Claims Tribunal (Clarendon press, Oxford, 1996).

Barlow Maude and Clarke Tony MAI: The Multilateral Agreement on Investment and the threat to American Freedom (Stoddart, New York,1998).

Beurier Jean Pierre and Kiss Alexandre Droit International de l'Environnement (3ed., Pedone, Paris, 2004).

Beveridge, Fiona Globalisation and International Investment (Aldershot, England; Burlington, VT: Ashgate, 2005).

Beveridge, Fiona The Treatment and Taxation of Foreign Investment Under International Law: Towards International Disciplines (Manchester University Press, Manchester, 2000).

Bishop, Doak R, Crawford, James and Reisman Michael W Foreign Investment Disputes: Cases, Materials, and Commentary (Kluwer Law International; The Hague, 2005).

Blackaby, Nigel, Paulsson, Jan and Reed, Lucy Guide to ICSID arbitration (Kluwer Law International, The Hague, 2004).

Carreau Dominique and Juilliard Patrick Droit International Economique (3ed, Dalloz, Paris 2007).

Davey William and Jackson John Legal problems of international economics relations (2ed, West publishing Co, St Paul, 1986).

Decaux, Emmanuel, Imbert, Pierre Henri and Pettiti Louis-Edmond (dir.) La Convention Européenne des Droits de l'Homme, Commentaire Article par Article (2ed, Economica, Paris, 1999).

Dolzer Rudolf and Schreuer Christoph Principles of International Investment Law (1ed., Oxford University Press, New York, 2008).

Henkin Louis, Pugh Richard, Schachter Oscar and Smit Hans International Law: Cases and Materials (3ed, MN: West Publishing, St Paul, 1988).

Herdeggen, Matthias Internationales Wirtschaftsrecht. Ein Studienbuch (Beck, 2002).

Khan, Philippe, and Wälde, Thomas W. New Aspects of International Investment Law (Martinus Nijhoff Publlishers, Leiden-Boston, 2007). 
Knahr Christina and Reinisch August (eds) International Investment Law in Context (Eleven International Publishing, Utrecht, 2008).

Larkin, Judy Strategic Reputation Risk Management (Macmillan Palgrave, London, 2002).

Lowenfeld, Andreas F International Economic Law (Oxford University Press, 2008).

McLachlan, Campbell, Shore Laurence and Weiniger Matthew International Investment Arbitration: Substantive Principles (Oxford University Press, Oxford, New York, 2007).

Muchlinski, Peter T Multinational Enterprises and the Law (Oxford: Blackwell, 1999).

Muchlinski, Peter, Ortino, Federico and Schreuer Christoph (eds) The Oxford Handbook of International Investment Law (Oxford University Press, New York, 2008).

Newcombe Andrew and Paradell Lluís Law and Practice of Investment Treaties. Standards of Treatments (Kluwer Law International, 2009).

Nye, Joseph H. The Paradox of American Power - Why the World's Only Superpower Can't Go it Alone (1ed, Oxford University Press, Oxford, 2002).

Oman, Charles Quelles Politiques pour Attirer les Investissements Directs Etrangers? Une Etude de la Concurrence entre Gouvernements (OCDE, Paris, 2000).

Ortino, Federico, Sheppard, Audley and Warner, Hugo Investment Treaty Law: Current Issues Volume 1 (British Institute of International and Comparative Law, London, 2006).

Paulsson Jan Denial of Justice in International Law (Cambridge University Press, Cambridge, 2005).

Sands, Philippe Principles of International Environmental Law (2ed, Cambridge University Press, Cambridge, 2003).

Schreuer Christophe The ICSID Convention: A Commentary (Cambridge University press, Cambridge 2001).

Seidl-Hohenveldern, Ignaz Collected Essays on International Investments and International Organizations (Kluwer Law International, The Hague, 1998).

Shahrjerdi, $\mathrm{P}$ and Tomkievicz V Le Procès Equitable et Enchevêtrement des Espaces Normatifs (Société de Législation Comparée, Paris, 2003).

Simma Bruno and Verdross Alfred Universelles Völkerrecht: Theorie und Praxis (3ed, Duncker \& Humblot, Berlin, 1984). 
Small, D Réglement des Différends entre Investisseurs et Etats d'accueil dans un Accord Multilatéral sur l'Investissement (Pedone, Paris, 1999).

Shaw, Malcolm N International Law (5ed, Cambridge University Press, Cambridge, 2003).

Sornarajah, M The International Law on Foreign Investment (2ed, Cambridge University press, Cambridge, 2004).

Sornarajah, M The Settlement of International Disputes (Kluwer Law International, The Hague, 2000).

Subedi Surya P International Investment Law Reconciling Policy and Principle (Hart Publishing, Oxford and Portland, Oregon, 2008).

Tudor Ioana The Fair and Equitable Treatment Standard in the International Law of Foreign Investment (Oxford University Press, Oxford, 2008).

Van Harten, Gus Investment Treaty Arbitration and Public Law (Oxford University Press, Oxford, 2007).

\section{B Book Chapters and Articles}

Asante S K B "Droit International et Investissements" in Bedjaoui Mohammed Droit International. Bilan et Perspectives (Pedone/UNESCO, Paris, 1991).

Asante S K B "International Law and Foreign Investments: A Reappraisal" (1988) 37 ICLQ 588.

Bahiigwa Godfrey "The Impact of Trade and Investment Policies on the Environment: Uganda's Fisheries Industry" in OECD Assessing the Environmental Effects of Trade Liberalisation Agreements (OECD, Paris, 2000).

Banifatemi Yas and Gaillard Emmanuel "The Meaning of "and" in Article 42(1), Second Sentence, of the Washington Convention: The Role of International Law in the ICSID Choice of Law Process" (2003) 18 ICSID Rev 375

Borchard E M "Responsibility of States for Damage Done in their Territory to the Person or Property of Foreigners" (1926) 20 AJIL 738.

Condon Bradly J "GATT Article XX and Proximity of Interests: Determining the Subject Matter of Paragraphs b and g" (2005) 10 UCLA Journal of International Law and Foreign Affairs. 
Delaume Georges R "Recognition and Enforcement of State Contract Awards in the United States: A Restatement” (1997) 91 AJIL 476.

Diehl Alexandra N "Tracing a Success Story or "The Baby Boom of BITs" Characteristics and Particularities of the Tight Net of Bilateral Investment Treaties Existing Today" in Knahr Christina and Reinisch August International Investment Law in context (Eleven International Publishing, Utrecht, 2008).

Dolzer Rudolf "Indirect Expropriations: New Developments?" (2002) 11 N Y U Envtl L J 64 .

Frank Susan D "Foreign Direct Investment, Investment Treaty Arbitration and the Rule of Law" (2007) 19 Pacific McGeorge Global Business \& Dev L J 337.

Gagné Gilbert and Morin Jean-Frédéric "The Evolving American Policy on Investment Protection: Evidence From Recent FTAs and the 2004 Model BIT” (2006) 9(2) JIEL 357.

Gaillard Emmanuel "Centre International pour le Règlement des Différends Relatifs aux Investissements" (1997) Chronique des sentences arbitrales, 124 Journal du Droit International 277.

Gantz A David "Reconciling Environmental Protection and Investor Rights under Chapter 11 of NAFTA" (2001) 31 Envtl L Rep 10646.

Goodman James "Stopping the Juggernaut: the Anti-MAI Campaign" in Goodman James and Ranald Patricia (eds) Stopping the Juggernaut: Public Interest Versus the Multilateral Agreement on Investment (Pluto Press, Annandale, 2000).

Hepple Bob "New Approaches to International Labour Regulation" (1997) 26 Ind L J 353.

Hirsch, Moshe "Interactions between Investment and Non-Investment Obligations in International Investment Law" in Muchlinski, Peter, Ortino, Federico and Schreuer Christoph (eds) The Oxford Handbook of International Investment Law (Oxford University Press, New York, 2008).

Hujer Marc “Dieser Laden Hier Soll Explodieren” (17 December 2004) Suddeutsche 10.

Juillard, Patrick "L'évolution des Sources du Droit des Investissements" in Recueil des Cours de l'Académie de Droit International (Kluwer Law International, La Haye, 1997).

Kaufmann-Kohler Gabrielle "Is Consistency a Myth" in Emmanuel Gaillard and Yas Banifatemi (eds) Precedent in International Arbitration (Juris Publishing, 2008).

Kobrin Stephen J "The MAI and the Clash of Globalizations" (1998) 112 Foreign Policy 97. 
Kolo Abba and Wälde Thomas "Confiscatory Taxation under Customary International law and Modern Investment Treaties” (1999) 4 CEPMLP I J 17.

Kolo Abba and Wälde Thomas "Coverage of Taxation Under Modern Investment Treaties" in Peter Muchlinski, Federico Ortino and Christoph Schreuer (eds) The Oxford Handbook of International Investment Law (Oxford University Press, New York, 2008).

Kolo Abba and Wälde Thomas "Environmental Regulation, Investment Protection and Regulatory Taking in International Law" 50 ICLQ 811.

Lauterpacht Elihu The Drafting of Treaties for the Protection of Investments (1962-1963) 18 ICLQ.

McLachlan Campbell "Investment Treaties and General International Law" (2008) 57 ICLQ 361.

Naewmalee Kiratipong "Protecting Foreign Investments against Expropriation Measures: Risks and Concerns Related to the New Draft Amendment of the Foreign Business Act of 1999” (2007) 22 TDRIQR, 20.

Parra Antonio R "Applicable Law in Investor-State Arbitration" in Rovine Michael (ed) Contemporary Issues in International Arbitration and Mediation: the Fordham Papers I (Martinus Nijhoff, Leiden, 2008).

Park William W "Arbitration and the Fisc: NAFTA's Tax Veto" (2001) 2 Chi J Intl L 231.

Park, William W "Expropriation and Taxation in the NAFTA" in Weiler, Todd (ed) Investment Law and Arbitration: Past Issues, Current Practice, Future Prospects (Transnational Publishers, New York, 2004).

Reif L C "Conciliation as a Mechanism for the Resolution of International Economic and Business Disputes" (1991) 14 Fordham International Law Journal 578.

Reinisch August "Expropriation" in Muchlinski, Peter, Ortino, Federico and Schreuer Christoph (eds) The Oxford Handbook of International Investment Law (Oxford University Press, New York, 2008).

Rubins N "L'affaire Loewen c. Etats-Unis : Les Pays Exportateurs de Capital comme Défenseurs dans l'Arbitrage International" in ENA Nouveaux développements dans le contentieux arbitral transnational relatif à l'investissement international (ENA Actes du colloque, Pedone, Paris, 2004).

Salacuse Jeswald W "The Treatification of International Investment Law: A Victory of Form over Life? A crossroads crossed?” (2006) 3 TDM 1. 
Schreuer Christoph "Fair and Equitable Treatment" (2005) 6 JWIT 357.

Schreuer Christoph "Fair and Equitable Treatment: Interactions with Other standards" (2007) 4 TDM 26.

Shine, Clare "Environmental Protection Under the Energy Charter Treaty" in Wälde, Thomas W (ed) The Energy Charter Treaty: A Gateway to East-West Trade Relations (Kluwer Law International, London, 1996).

Spiermann Ole "Applicable Law" in Muchlinski Peter, Ortino Federico and Schreuer Christoph (eds) The Oxford Handbook of International Investment Law (Oxford University Press, New York, 2008).

Spiermann Ole "Individual Rights, State Interests and the Power to Waive ICSID Jurisdiction under Bilateral Investment Treaties" (2004) 20 Arb Intl 179.

Story Louise "Mattel Recalls Toys Made in China" (2 august 2007) International Herald Tribune.

Tupman Michael W "Case Studies in the Jurisdiction of the International Centre for Settlement of Investment Dispute" (1986) 35 ICLQ 813.

Vandevelde K J "A brief History of International Investment Agreements" (2005) 12 UCDJILP 162.

Vasciannie Stephen "The Fair and Equitable Treatment Standard in International Investment Law and Practice" (1999) 70 BYIL 99.

Verhoosel Gaëtan "Foreign Direct Investment and Legal Constraints on Domestic Environmental Policies: Striking a "Reasonable" Balance between Stability and Change" (1998) 29 (4) Law \& Pol'y Int'l Bus 453.

Wagner J Martin "International Investment, Expropriation and Environmental Protection" (1999) 29 Golden Gate U L Rev 465.

Wälde Thomas and N'Di George "Stabilising International Investment Commitments: International Law Versus Contract Interpretation” (1996) CEPMLP I J 1.

Weil Prosper "The State, The Foreign Investor and International Law: The No Longer Stormy Relationship of a Ménage à Trois” (2000) 15 ICSID Rev - FILJ 401.

Weiler Todd "NAFTA Arbitration and the Growth of International Economic Law" (2002) 36 Can Bus L J 405. 
Weiler Todd "The Ethyl Arbitration: First of Its Kind And A Harbinger of Things To Come" (2000) 11 Am Rev Intl Arb 187.

Weston Burns H "Constructive Takings' under International Law: A Modest Foray into the problem of Creeping Expropriation" (1975) 16 Va J Intl L 103.

Ziadé N G “ICSID Conciliation” (1996) 13/2 News from ICSID 3.

\section{Reports and other Documents from International Organisations and Institutes}

American Law Institute Restatement of Law the Third, Foreign Relations Law of the United States (American Law Institute Publishers, St. Paul, Minnesota, 1987).

Centre for International Environment Law and International Institute for Sustainable Development Revising the UNCITRAL Arbitration Rules to Address Investor-State Arbitrations (CIEL, IISD, Winnipeg, Manitoba, 2007).

Chambre de Commerce et d'Industrie de Paris Comment Accroître la Sécurité des Investissements Français à l'Etranger? (Rapport adopté par l'Assemblée Générale, Paris, 2000).

Conciliation Rules of the United Nations Commission on International Trade Law (1980) GA Res. 35/52, 20 ILM 300.

Conseil Economique et Social Les relations entre l'Union Européenne et la Fédération de Russie (Rapport présenté par Lucien Bouis, Paris, 2004).

Cosbey, Aaron, Mann Howard, and Von Moltke Konrad Comments on ICSID Discussion Paper, Possible Improvements of the Framework for ICSID Arbitration (IISD, Winnipeg, Manitoba, 2004).

Cosbey, Aaron, Mann Howard, Peterson Luke Eric and Von Moltke Konrad Investment and Sustainable Development, A Guide to The Use and Potential of International Investment Agreements (IISD, Winnipeg, Manitoba, 2004).

Cosbey, Aaron, Mann Howard, Peterson Luke Eric and Von Moltke Konrad Model International Agreement on Investment for Sustainable Development (IISD, Winnipeg, Manitoba, 2005).

Cosbey, Aaron, Mann Howard, Peterson Luke Eric and Von Moltke Konrad IISD Model International Agreement on Investment for Sustainable Development, Negociator's Hanbook (2ed, IISD, Winnipeg, Manitoba, 2006).

Declaration of the US representative at the VIth Commission of United Nations General Assembly (11 November 1977) 72 AJIL 377. 
Frederiksson P Trade, Global Policy, and the Environment (World Bank, Washington DC, 1999).

Hafner Gerhard Risks Ensuing from Fragmentation of International Law in Report of the International Law Commission (ILC Report) of the United Nations about the division of the international normative universe (International Law Commission (ed..) Report of the 52th session Doc. A/55/10, 2000).

ILC Fragmentation of International Law: Difficulties Arising from the Diversification and Expansion of International Law (Report of the Study Group of the International law Commission UN Doc A/CD.4/L702, 18 July 2006 (ILC Fragmentation Conclusions)).

International Monetary Fund Guidelines on Conditionality; Principles, Modalities, Evaluation and Review (IMF, Washington, 2002). Available at: http://www.imf.org/External/np/pdr/cond/2002/eng/guid/092302.pdf (last accessed 19 February 2009).

Kinsbury A and Schill S Investor-State Arbitration, Fair and Equitable Treatment, Proportionality, and the Emerging Administrative Law of Global Governance (International Congress of Commercial Arbitration, Dublin, 9 June 2008).

Mann Howard and Marshall Fiona Good Governance and the Rule of Law: Express Rules for Investor-State Arbitrations Required (IISD, Winnipeg, Manitoba, 2006).

Mann Howard and Von Moltke Konrad NAFTA's Chapter XI and the Environment (IISD, Winnipeg, Manitoba, 1999).

Mann Howard International Investment Agreements, Business and Human Rights: Key Issues and Opportunities (IISD, Winnipeg, Manitoba, 2008).

Mann Howard Investment Agreements and the Regulatory State: Can Exceptions Clauses Create a Safe Haven for Governments? (Issues in International Investment Law, Background Papers for the Developing Country Investment Negotiator's Forum, IISD, Singapore, 2007).

Mann Howard The Final Decision in Methanex v United States: Some New Wine in Some New Bottles (IISD, Winnipeg, 2005).

Mann Howard The Right of States to Regulate and International Investment Law Comment in Expert Meeting on the Development Dimension of FDI: Policies to Enhance the Role of FDI in Support of the Competitiveness of the Enterprise Sector and the Economic Performance of Host Economies, Taking into Account the Trade/Investment Interface, in the National and International Context (IISD, Geneva, 6-8 November 2002). 
Marshal Fiona and Yu Vicente Investors' Obligations and Host State Policy Space $2^{\text {nd }}$ Annual Forum of Developing Country Investment Negotiators (IISD, Marrakech Maroc, 3-4 November 2008).

Moltke Von Konrad Discrimination and Non-Dicrimination in Foreign Direct Investment Mining Issues (OECD Global Forum on International Investment, Conference on Foreign Direct Investment and Environment, Lessons to be Learned from the Mining Sector, Paris, 2002).

Moltke Von Konrad An International Investment Regime? Issues of Sustainability (IISD, Winnipeg, Manitoba, 2000).

NAFTA Free Trade Commission Clarifications Related to NAFTA Chapter 11 (31 July 2001). Available at http://www.worldtradelaw.net/nafta/chap11interp.pdf (last accessed 20 May 2009).

Nordström H and Vaughan S Trade and Environment (WTO, Geneva, 1999).

OCDE Gestion Publique (OCDE Base de Données sur la Réglementation, Paris, 2002).

OCDE Perspectives de l'investissement international (OCDE, Paris, 2003).

OECD A Multilateral Agreement on Investment: Report by the Committee on International Investment and Multinational Enterprises (CIME) and the Committee on Capital Movements and Invisible Transactions (CMIT) (Document OECD/GD(95)65, Paris, 1995).

OECD Emerging Systematic Risks in the 21st Century, An agenda for action (OECD, 2003).

OECD International Investment Law: Understanding Concepts and Tracking Innovations. A Companion Volume to International Investment Perspectives (OECD, 2008).

OECD Interpretation of the Umbrella Clause in Investments agreements (Working Papers on International Investment Number OECD, 2006).

OECD MAI Negotiating Text (24 April 1998) (OECD Directorate for Financial, Fiscal and Enterprise Affairs, Paris, 1998).

OECD Best Practices for Budget Transparency (PUMA/SBO(2000)6/FINAL, OECD, Paris, 1998).

OECD Guidelines for Multinational Enterprises (OECD, Paris, 2000). 
OECD Public Sector Transparency and International Investment Policy (OECD Directorate for Financial, Fiscal and Enterprise Affairs, 11 April 2003).

OECD Report of the Drafting Group Concerning the Protection of Investor Rights Arising from Other Agreements (Negotiating Group on the Multilateral Agreement on Investment (MAI), DAFFE/MAI/DG1 (96) 1/REV1, 18 March 1996).

OMC Document d'Orientation sur la Transparence (OMC Groupe de Travail des Liens entre Commerce et Investissement, WT/WGTI/W/155, 2003).

Peterson Luke Eric Bilateral Investment Treaties and Development Policy-Making (IISD, Winnipeg, Manitoba, 2004).

Peterson, Luke Eric Australia-U.S. FTA Sets Precedent with Lack of Investor-State Dispute Mechanism (IISD, Canada, 2004).

The Final Decision in Methanex v United States: Some New Wine in Some New Bottles (IISD, Winnipeg, Manitoba, 2005).

UNCTAD Development Implications of International Investment Agreements (United Nations Publications, New York and Geneva, 2007).

UNCTAD Employment (United Nations Publications, New York and Geneva, 2000).

UNCTAD Environment (United Nations Publications, New York and Geneva., 2001).

UNCTAD International Invesment Agreements : Key Issues Volume II (United Nations Publications, New York and Geneva, 2004).

UNCTAD International Investment Disputes on the Rise - Occasional Note (UNCTAD/WEB/ITE/IIT/2004/2, 29 November 2004).

UNCTAD International Invesment Instruments : A Compendium Volume XIII and XIV (United Nations Publications, New York and Geneva, 2005).

UNCTAD Investor-State Dispute Settlement and Impact on Investment Rule Making (United Nations Publications, New York and Geneva, 2008).

UNCTAD Key Terms and Concepts in IIAs: A Glossary UNCTAD (United Nations Publications, New York and Geneva, 2004).

UNCTAD Most-Favoured-Nation Treatment (United Nations Publications, New York and Geneva, 1999).

UNCTAD National Treatment (United Nations Publications, New York and Geneva, 1999). 
UNCTAD Taking of Property (United Nations Publications, New York and Geneva, 1999).

UNCTAD World Investment Report 1993: Transnational Corporations as Integrated International Production (United Nations Publications, New York and Geneva, 1993).

UNCTAD World Investment Report 2004. The Shift Towards Services (United Nations Publications, New York and Geneva, 2004).

UNCTAD World Investment Report 2009 (United Nations Publications, New York and Geneva, 2009).

United States, Amended Statement of Defense of the Respondent United States of America (5 December 2003).

UNDP Practice note "Public Administration Reform” (New York, 2005).

Weber J. Existing proposals on bilateral and multilateral investment agreements and practices towards codes of conduct on TNCs and governments with respect to FDI in UNCTAD-Civil Society Dialogue on Selected Development Issues Being Addressed by the United-nations System (Papers Prepared in Support of the Issues Discussed, Geneva, 2002).

WTO European Communities - Measures Affecting Asbetos and Asbetos-Containing Products: Additional Procedure Adopted under Rule 16(1) of the Working Procedures for Appellate Review (Report of the Appellate Body, WTO Doc WT/DS/135/9, 8 November 2000).

WTO International Trade Statistics 2003 (WTO Publications, Geneva, 2003).

\section{Theses, Dissertations and Papers}

García-Bolívar, Omar E International Law on Foreign Investment at a Crossroads: the Need to Reform (2008). Available at: http://works.bepress.com/cgi/viewcontent.cgi?article=1002\&context=0mar_garcia_boliva $\underline{\mathrm{r}}$ (last accessed 04 February 2009).

Guzman Andrew Explaining the Popularity of Bilateral Investment Treaties: Why LDCs Sign Treaties That Hurt Them (Jean Monnet Center Working Papers, New York University School of Law, 1997). Available at: http://www.jeanmonnetprogram.org/papers/97/97-12.html (last accessed 27 April 2009).

Linden Claudia Too Many Friends for a Good Part? An Analysis of the Latest Developments in Third Party Participation in Investment Arbitration with Special 
Proliferation of Amicus Curiae Briefs (LLM Research Paper, Victoria University of Wellington, 2008).

Schreuer Christoph The Relevance of Public International Law in Commercial Arbitration: Investment Disputes (2005).

Tieleman Katia The failure of the Multilateral Agreement on Investment (MAI) and the Absence of a Global Public Policy Network (Case Study for the UN Vision Project on Global Public Policy Networks, European University Institute, Firenze and Harvard University), 2000).

Vincentelli Ignacio The Uncertain Future of ICSID in Latin America (Independent Research Paper, University of Miami School of Law, 2008).

Weisburd Arthur Mark The International Court of Justice and the Concept of State Practice (UNC Legal Studies Research Paper No. 1282684, University of North Carolina at Chapel Hill - School of Law, 2008).

\section{E United Nations Publications and Documents}

Declaration of the United Nations Conference on the Human Environment (Stockholm Declaration) (5 - 12 June 1972) UN Doc A/CONF/48/14/REV 1 reprinted in 11 ILM 1416 (1972).

UNCTC and ICC, Bilateral Investment Treaties 1959-1991 UN Doc ST/CTC/136 (New York, 1992).

UNGA Resolution 1803 (XVII) on Permanent Sovereignty Over Natural Resources (14 December 1962) A/RES/1803.

UNGA Resolution 3201 (S-VI) Declaration on the Establishment of a New International Economic Order (1 May 1974) A/RES/3201.

UNGA Resolution 3202 (S-VI) Programme of Action on the Establishment of a New International Order (1 May 1974) A/RES/3202.

UNGA Resolution 3281 (XXIX) Containing the Charter of Economic Rights and Duties of States (12 December 1974) A/RES/29/3281.

\section{INTERNET RESOURCES}

ASIL (American Society of International Law) http://www.asil.org 
ICJ (International Court of Justice) http://www.icj-cij.org/

ICSID (International Centre for Settlement of Investment Disputes) http://icsid.worldbank.org/ICSID/Index.jsp

IISD (International Investment for Sustainable Development) http://www.iisd.org

ITA (Investment Treaty Arbitration) http://ita.law.uvic.ca/

NAFTA (North America Free Trade Agreement) http:/www.naftalaw.org

OECD (Organisation for Economic Cooperation and Development) http://www.oecd.org/

UNCITRAL (United Nations Commission on International Trade Law) http://www.uncitral.org/uncitral/en/index.html

UNCTAD (United Nations Conference for Trade and Development) http://globstat.unctad.org

UNCTAD Investment Instruments Online - Bilateral Investment Treaties: http://www.unctadxi.org/templates/DocSearch_779.aspx 